\title{
I. Cmammi
}

Василь Орлик

доктор історичних наук, професор, завідувач кафедри історії, археології, інформаційної та архівної справи, Центральноукраїнський національний технічний університет (Кропивницький, Україна)

\section{Vasyl Orlyk}

Doctor of history (dr. habil), Professor, Head of the Department of History, Archeology, Information and Archival Affairs Central Ukrainian National Technical University (Kropyvnytskyi, Ukraine)

v.m.orlik@gmail.com

ORCID: https://orcid.org/0000-0002-7947-9557

ResearcherID: C-1025-2019

\section{ЗНАХІДКИ АНТИЧНИХ МОНЕТ VI-I СТ. ДО Н. Е В БАСЕЙНІ Р. ТЯСМИН}

\section{THE FIND OF ANCIENT COINS IN THE TIASMYN RIVER BASIN FROM THE SIXTH TO THE FIRST CENTURY BC}

\section{Анотація.}

Мета статті полягає у дослідженні та систематизаиії монетних знахідок у басейні р. Тясмин й на прилеглих територіях та введення їх до наукового обігу. Теоретико-методологічні основи дослідження складає сукупність загально-наукових та нумізматичних методів, які, найперше, визначаються наявною джерельною базою та ії оиінкою щодо достовірності чи недостовірності. Наукова новизна. Протягом останніх десятиріч значно збільшилася кількість відомих знахідок монет давньогрецьких державних утворень на поселеннях VI-I cm. до н.е е. як у басейні р. Тясмин, так $i$ загалом у Дніпровському Правобережному Лісостепу, зокрема монет античних міст Північного Причорномор'я: Ольвії, Пантікапею, Херсонесу, Керкинітіди, Тіри, а також монет інших давньогрецьких держав. Проте, узагальнююче комплексне дослідження знахідок монет VI - Icm. до н.е. в басейні р. Тясмин та на прилеглих територіях відсутнє, що й обумовило звернення автора до иієї теми та написання даної статті. Основні результати дослідження. Аналіз знахідок 167 античних монет VI-I cm. до н.е. на території басейну р. Тясмин дозволяс виокремити 23 пункти зосередження таких знахідок, зокрема 19 населених пунктів, поблизу яких знайдено більще однієї монети, $і 4$ населених пункти, поблизу яких виявлено монетні скарби. Усе це дозволяє висловити припущення 
про участь ичих монет у товарно-грошових відносинах місцевого населення із греками, хоча, зрозуміло, ці відносини не були настільки розвинутими, як у грецьких колоніях Північного Причорномор'я. Майже 75 \% знахідок складають монети Ольвї, зокрема 23 монети - кінця VI-початку IV cm. до. н.е., 5 монет близько 400-380 рр. до. н.е., 1 монета - 400-370 рр. до н.е., 1 монета - 380360 рр. до н.е., 11 монет - 360-350 рр. до н.е., 4 монет - 350-310 рр. до н.е., та 78 «борисфенів» (кінець IV-20-ті роки III cm. до. н.е.). Лише 2,99\% усіх знахідок складають монети Пантікапея - 5 монети кіния IV cm. до. н.е. Усе викладене ставить під сумнів тезу деяких дослідників про те, щзо у IV cm. до н.е. Ольвія втратила провідну роль у торгівлі з варварами, а ї̈ місце посів Боспор. Монетні знахідки басейну р. Тясмин свідчать про зворотне.

Ключові слова: басейн р. Тясмин, монетна знахідка, скарб, давньогрецька монета, Ольвія, Північне Причорномор'я, Дніпровський Правобережний Jicocmen.

\section{Abstract.}

The purpose of the article is to investigate and systematize coin finds from the sixth to the first century $B C$ in the Tiasmyn river basin and surrounding areas and to bring new finds into scientific circulation. Theoretical and methodological background of the investigation consists of the complexity of general scientific and numismatic methods which are, above all, determined by the existence of corpus of sources and its assessment of credibility or unreliability. Scientific novelty. The researchers of the history of the Dnieper Right Bank Forest-steppe of the first millennia BC divide in a separate group southern, border steppe territory, and the basin of the river Tiasmyn with adjacent territories within Kiev-Cherkassy region. The geographical scope of this group includes river Tiasmyn system in the present Cherkassy region and the territory where feeder from the headwaters of Tiasmyn are close to the right bank tributaries of the Southern Bug system (Hirskyi Tikych and Syniukha) and headwaters of Inhul and Inhulets in the northern part of the Kirovograd region. For the recent decades there can be observed a significant increasing in the number of the known coin finds of the state ancient Greek formations on the settlement of the sixth to the first century BC, which were found in the Tiasmyn river basin as well as overall in Dnieper-Right-Bank-Forest-steppe territory and including coins from the antique city-states of the Northern Black Sea region, such as Olbia, Panticapaeum, Chersonesus, Kerkinitis, Tyras and coins from other Ancient Greek city-states. Although generalized complex investigation of the coin finds of the sixth to the first century $B C$ in the Tiasmyn river basin and surrounding areas are not present, which caused appealing of the author to this topic and writing the article. Main results of the research. The Population that had been living on the territory of the Dnieper Right Bank Forest-steppe, including Tiasmyn river basin from sixth to the 
first century BC had economic relations with Greece antique world including Olbia. This is evidenced by the significant amount of the numismatic sources in the occupation earth of the settlements. In this case it is presented by the coins from the ancient Greek state formations, which were lost by their owners.

The author had analysed 167 ancient coins, which were found in the Tiasmyn basin and had compiled a corresponding Catalogue. Information about the finds of these coins located in diverse sources: museum collections, above mentioned researcher studies, evidence of area studies specialists, and materials on the forums of the treasure hunters. Analysing 167 coins finds from the sixth to the first century BC on the Tiasmyn river basin area it is possible to highlight 23 points of such coin finds concentration. There are 19 settlements where had been found more than 1 coin and 4 settlements were had been found monetary treasures nearby. All this gives grounds for suggestion that these coins were involved in goods-money relations of the local inhabitants with Greeks. It is conceivable that this level of relations was not developed to the degree that Greek colonies of in the Northern Black Sea region had. These finds indicate economic, including trade relations of the population from the Tiasmyn river basin with the ancient world, which had developed monetary circulation. Nearly 75 per cent constitute coins from Olbia. Coins are divided by the types and coinage periods for «Dolphins» (end of the sixth century beginning of the fourth century $B C$ ) they are 23 coins, "Reduced Asses» (c. 400-380 BC) are represented by 5 coins, «Chalk» (400-370 BC), «Dichalk» (380-360 BC), «Chalk» (360-350 BC) are represented by 11 coins, "Obol» with Demeter and city emblem (350-330 BC) account for 3 coins, 2 small coin with the head of Demeter (the end of the sixth century BC), "Borysthenes» (end of the sixth century - 20s of the third century BC) number 78 coins. Coins from Chersonesus constitute 4,19 per cent (4 coins of the fourth century $B C, 2$ coins of the beginning of the third century BC and 1 coin of the middle of the first century BC). Panticapaeum coins accounted for 2.99 per cent, all these coins are dated by the end of the sixth century BC. An insignificant number of Panticapaeum coins which were found in the Tiasmyn river basin in comparison with Olbian coins, call into thesis of some researchers that Olbia had lost its lead role in trade with barbarians in sixth century $B C$ and it was being replaced with Bosporus. Even the coins from the Makedonia, that was located far from Dnieper-Right-Bank-Foreststeppe amount 3,59 per cent (all the coins of the sixth century BC). The electrum staters from the Cyzicus city of Asia Minor constitute a rather significant per cent of finds. They are estimated at 8.38 per cent and played a major role in Mediterranean and Black Sea trade. If to talk about the coins minted in the second century BC, it is known only find of coin by the ruler Bithynia Prusias I Cholus, that was found in the Tiasmyn river basin, it is consistent with the coins minted circa 228-182 BC, so the end of the third century- the beginning of the second century BC. However, the near absence among finds coins dated second century BCE can demonstrate the leading role of Olbia in trade with the barbarian population of the Dnieper Right-Bank 
Forest-Steppe, including, in particular, trade with the population from the Tiasmyn river basin in the previous chronological period. In fact, Olbia got through the SkyroGalatic Invasion in the end of the third century BC, and the second century BC was rather difficult period in political and economic life of this Greece colony in northernwest Black Sea region. Numismatical sources, specifically coin finds confirm thesis that relationships of Olbia with Barbarian tribes of Northern Black Sea region decreased to the minimum. Recovery of economic relations of ancient Greeks with population of the Tiasmyn river basin happened after the entry of Olbia and other Greek colonies of the Northern Black Sea region to Kingdom of Pontus of Mithridates Eupator, that was confirmed by coin finds. The perspective of further research. The problem has been raised by us is complex and multifaceted, it requires further research, and above all, to reveal information about other finds of antique coins in this and other regions of the Dnieper Right-Bank Forest-Steppe in the period from the sixth to the first century $B C$.

Key words: Tiasmyn river basin, coin find, treasure, ancient Greek coin, Olbia, Northern Black Sea region, Dnieper Right-Bank Forest-Steppe.

Постановка проблеми. Дослідники історії Дніпровського Правобережного Лісостепу I тисячоріччя до н.е. виділяють у межах КисвоЧеркаського регіону його південну, прикордонну до степу територію, зокрема басейн р. Тясмин із прилеглими територіями, в окрему групу. Аналізуючи археологічні пам'ятки басейну p. Тясмин, В. Ільїнська та О. Тереножкін указують, що «до географічних рамок розглянутої групи входить система p. Тясмин у нинішній Черкаській області, а також територія, де притоки верхів’їв Тясмина близько стикаються із правобережними притоками системи Південного Бугу (Гірський Тикич, Синюха) та верхів'ям Інгулу й Інгульця у Північній частині Кіровоградської області» ${ }^{1}$. За розрахунками В. Полтавця, площа тясминської групи складає близько 6750 кв. км, i, на думку дослідника, «цілком достатня для перебування населення, максимальна припустима чисельність якого наприкінці VII - на початку V ст. до н. е., за деякими методиками розрахунків, мала становити близько 67,5 - 81 тис. осіб, що відповідає розмірам спільноти, потрібної для утворення розвиненого вождівства (50 тис. осіб)»².

Дослідники $\quad$ В. Ільїнська та О. Тереножкін виділяють 27 пам’яток скіфської доби, об'єднаних у Тясминську групу, зазначаючи, що «на підставі вивчення пам'ятників Придніпровського Лісостепу і особливо басейну р. Тясмин на теперішній час склалося враження про безперервний культурний розвиток від епохи пізньої бронзи до ранньослов'янського часу, охоплюючи період близько

\footnotetext{
${ }^{1}$ Ильинская, Тереножкин 1983: 230.

${ }^{2}$ Полтавець 2016: 7.
} 
півтори тисячі років» ${ }^{1}$. Стосовно періоду, монетні знахідки якого ми досліджуємо, то вчені в ньому виділяють молодшу журовську групу (середньоскіфську) - V ст. до н.е.; пізньоскіфські пам’ятники IV - початку III ст. до н.е.; зарубинецький час - кінець III ст. до н.е. - I ст. н.е.»². Таким чином, історія Дніпровського Правобережного Лісостепу, зокрема басейну р. Тясмин, другої половини І-го тисячоліття до н.е. має два основні періоди -скіфська доба та становлення зарубинецької культури. Серед цілого корпусу речових джерел, знахідки яких дозволяють ученим дослідити історію того чи іншого регіону, особливе місце посідають нумізматичні джерела, зокрема монетні знахідки.

Аналіз останніх досліджень і публікацій. Проблеми давньої історії населення басейну р. Тясмин має певне висвітлення у науковій літературі, зокрема у працях О. Тереножкіна та В. Ільїнської ${ }^{3}$, Н. Бокій ${ }^{4}$, О. Орлика С. Бессонової і В. Полтавця 6 та ін. Проте, в їхніх працях, практично, відсутні відомості про знахідки монет VI - I ст. до н.е. у даному регіоні. Ще за радянської доби вченими було сформовано тезу про відсутність грошового обігу в оточуючого давньогрецькі колонії варварського населення, і це безвідносно до того, чи йшлося про населення скіфської доби, чи вже про представників зарубинецької культури. Дослідниками стверджувалося, що мешканці Середнього Подніпров'я здійснювали виключно товарообмінні операції 3 грецькими колоніями в Північному Причорномор'і77. Щоправда, менш категоричним у даному питанні був видатний український археолог М. Брайчевський ${ }^{8}$. Знахідки ж бронзових монет давньогрецьких державних утворень на теренах Дніпровського Правобережного Лісостепу пояснювалися ученими тим, що вони випадково і в незначних обсягах потрапляли до даного регіону та могли використовуватися як сировина для виготовлення бронзових предметів ${ }^{9}$. Цікаво, що дослідники, які заперечували наявність саме товарногрошових відносин у населення скіфської доби, покликалися на Геродота, де він начебто указував на той факт, що місцеве скіфське населення не знає грошей i послуговується лише товарообмінними операціями. У той же час Геродот, описуючи території за р. Танаїд (Дон), де мешкали аргіппаї, вказував, що «скіфи, які заходять до них, обмінюються товарами» ${ }^{10}$. Як бачимо, батько історії у даному випадку писав лише про мінову торгівлю скіфів із мешканцями задоння, а механічне перенесення його тези на власне скіфів та всі підконтрольні скіфам землі, як мінімум, виглядає некоректним у науковому аспекті.

\footnotetext{
${ }^{1}$ Ильинская, Тереножкин 1983: 229.

2 там само: 229.

3 Тереножкин 1952.

${ }^{4}$ Бокий 1967; Бокий 1977.

${ }^{5}$ Орлик 2014.

${ }^{6}$ Бессонова, Полтавець 2015.

${ }^{7}$ Граков 1971; Анохін 1971: 424.

${ }^{8}$ Брайчевський 1964.

${ }^{9}$ Максимов 1982: 57.

${ }^{10}$ Геродот 1993: 186.
} 
Уперше в історіографії знахідки античних монет VI - I ст. до н.е. на території України досліджені відомим польським ученим М. Мельчариком ${ }^{1}$. Протягом останніх років з'являються публікації, в яких йдеться про численні знахідки монет ${ }^{2}$ на поселеннях скіфської доби Лісостепової зони, навіть знахідки монетних скарбів ${ }^{3}$. Дослідниця історії економіки Степової Скіфії Н. Гаврилюк, проаналізувавши нумізматичні знахідки на скіфських поселеннях, дійшла висновку, що «у IV ст. до. н.е. значення грошей в торгівлі між греками і скіфами порівнянно 3 попереднім періодом зростає» ${ }^{4}$. Ми цілком підтримуємо тезу українських археологів С. Скорого та Р. Зимовця про те, що знахідки монет «на поселеннях скіфської пори, в тому числі в культурному шарі, і в досить представницькій кількості, недвозначно вказують на те, що ними користувалося як грошовими засобами місцеве населення при розрахунку за товари або будьякі послуги 3 греками» ${ }^{5}$. 3 часу виходу статті С. Скорого та Р. Зимовця «До проблеми товарно-грошових відносин у населення Східноєвропейського Лісостепу в скіфську епоху», яка з'явилася у 2014 р., значно збільшилася кількість відомих знахідок монет давньогрецьких державних утворень на поселеннях VI-I ст. до н.е. як у басейні p. Тясмин, так i загалом у Дніпровському Правобережному Лісостепу, зокрема монет античних міст Північного Причорномор'я: Ольвії, Пантікапею, Херсонесу, Керкинітіди, Тіри, а також монет інших давньогрецьких держав. Проте, узагальнююче комплексне дослідження знахідок монет VI - I ст. до н.е. в басейні р. Тясмин і на прилеглих територіях відсутнє, що й обумовило звернення автора до цієї теми і написання даної статті.

Теоретико-методологічні основи дослідження складає сукупність загальнонаукових (аналіз і синтез, індукція й дедукція, системний аналіз), історичних (періодизації, історико-порівняльний, історико-системний) та нумізматичних методів, які найперше визначаються наявною джерельною базою $^{6}$ та оцінкою щодо ії достовірності чи недостовірності ${ }^{7}$. Використання під час підготовки статті двох основних нумізматичних джерел: монет (зображень монет) та монетних знахідок, - обумовлює застосування власне нумізматичних методів, зокрема ідентифікації та типологізації монет, методу візуального аналізу та порівняльного методу (дозволяє виявити відмінності деталей малюнку різних різновидів монет у межах їх одного типу) а також використання оптичних приладів та топографування місць знахідок.

\footnotetext{
${ }^{1}$ Mielczarek 1989.

2 Скорый \& Зимовец 2014. Шостопал 2016; Ляшко 2017-a; Ляшко 2017-b; Orlyk \& Orlyk 2020; Орлик 2020-a; Орлик 2020-b; Орлик 2020-с; Орлик 2021.

${ }^{3}$ Коцур 2017; Mielczarek \& Orlyk 2019; Орлик, Коцур \& Циганенко 2019; Шостопал 2007 та ін.

${ }^{4}$ Гаврилюк 2013: 491.

${ }^{5}$ Скорый \& Зимовец 2014: 145.

${ }^{6}$ Орлик \& Орлик 2019: 5-26.

${ }^{7}$ Мизгін 2015: 182.
} 
Формулювання мети статті полягає у дослідженні та систематизації знахідок монет VI-I ст. до н.е. в басейні р. Тясмин і на прилеглих територіях та введення їх до наукового обігу.

\section{Виклад основного матеріалу дослідження.}

На території Дніпровського Правобережного Лісостепу, зокрема в басейні p. Тясмин у VI-I ст. до н.е. проживало населення, яке мало економічні зв'язки із грецьким античним світом, зокрема з Ольвією. Про це свідчить значна кількість нумізматичних джерел у культурних шарах поселень, у даному випадку - монет давньогрецьких державних утворень, загублених свого часу їхніми власниками. Під час написання даної статті автором проаналізовано 149 античних монет, знайдених у басейні р. Тясмин (див. Каталог). Відомості про знахідки цих монет містяться у різнопланових джерелах: музейних колекціях, згаданих вище працях дослідників, свідченнях краєзнавців та матеріалах форумів скарбошукачів.

Відомий британський учений Філіп Грірсон поділяє монетні знахідки на археологічні та випадкові ${ }^{1}$, включаючи до останніх три групи: знахідки одиничних монет, скупчення знахідок одиничних монет та скарби ${ }^{2}$. Саме цей підхід ми використовуємо для аналізу знахідок давньогрецьких монет у басейні р. Тясмин.

До археологічних знахідок належать лише 2 монети: «дельфін» (№3) ${ }^{3}$ та «Борисфен» (№115). Обидві монети знайдені на поселенні скіфської доби, розташованому між населеними пунктами Жаботин, Михайлівка і Грушківка Черкаської області. Монети зберігаються в Історичному музеї Кам'янського державного історико-культурного заповідника* .

Усі інші зафіксовані знахідки складають категорію випадкових знахідок, переважна більшість яких стала відома завдяки розвиткові приладового металопошуку.

Серед корпусу випадкових знахідок у басейні р. Тясмин одиничні знахідки складають 26 монет $(15,57 \%)$.

Скупчення знахідок одиничних монет у басейні р. Тясмин та прилеглих територій зафіксовано поблизу таких населених пунктів: с. Мельники, Медведівська сільська об'єднана територіальна громада (далі - ОТГ), Черкаський p-н, Черкаська обл. (3 ольвійські монети - «дельфіни»); с. Розсошинці, Чигиринська міська ОТГ, Черкаський p-н, Черкаська обл. (8 ольвійських монет - «дельфінів»); с. Жаботин, Михайлівська сільська ОТГ, Черкаський р-н, Черкаська обл. (1 ольвійська монета - «дельфіни», 1 ольвійська монета - «борисфен»); с. Лубенці, Миха́йлівська сільська ОТГ, Черкаський р-н, Черкаська обл. (2 мідних оболи Понтійської держави Мітрідата Свпатора);

\footnotetext{
${ }^{1}$ Grierson 1975: 125.

2 Ibidem: 128-136.

3 Ляшко 2017-b: 299.

* Ми вдячні директорові Кам'янського державного історико-культурного заповідника Ю.Ю. Ляшку за надану інформацію.
} 
с. Суботів, Чигиринська міська ОТГ, Черкаський p-н, Черкаська обл. (1 ольвійська монета - «дельфіни», 1 монета Херсонесу); с. Макіївка, Ротмістрівська сільська ОТГ, Черкаський р-н, Черкаська обл. (1 ольвійська монета - «редукований асс», 1 ольвійська монета - «борисфен», 1 монета Пантикапею); с. Райгород, Михайлівська сільська ОТГ, Черкаський p-н, Черкаська обл. (1 ольвійська монета - «редукований асс», 2 ольвійські монети «борисфени», 1 монета Македонії), с. Вдовичине, Чигиринська міська ОТГ, Черкаський p-н, Черкаська обл. (1 ольвійська монета - обол, 1 монета Македонії); між селами Капітанівка, Новомиргородська міська громада, Новоукраїнський р-н, Кіровоградська обл. та Пастирське, Тернівська сільська ОТГ, Черкаський р-н, Черкаська обл., на межі областей (1 ольвійська монета «редукований асс», 1 ольвійська монета - «борисфен»); с. Леськи, Черкаський p-н, Черкаська обл. (2 монети Херсонесу); між селами Голиківка, Медведівська сільська ОТГ, Черкаський p-н, Черкаська обл., і Поселянівка, Олександрівська селищна громада, Кропивницький р-н, Кіровоградська обл. (2 ольвійські монети - »дельфіни»); між селами Калинівка та Веселий Кут, Дмитрівська сільська громада, Кропивницький р-н, Кіровоградська обл. (1 ольвійська монета - »редукований асс», 1 монета Істрії); с. Цибулеве, Дмитрівська сільська громада, Кропивницький р-н, Кіровоградська обл. (2 ольвійські монети - «халк» першої половини IV ст. до н.е. і «дихалк» кінця III ст. до н.е.); с. Михайлівка, Олександрівська селищна громада, Кропивницький р-н, Кіровоградська обл. (1 ольвійська монета - «дельфін», 1 ольвійська монета - «халк»); с. Іванівка, Олександрівська селищна громада, Кропивницький р-н, Кіровоградська обл. (1 ольвійська монета - «дельфіни», 1 монета Понтійської держави Мітрідата Евпатора м.д. Тіра); с. Підлісне, Олександрівська селищна громада, Кропивницький р-н, Кіровоградська обл. (1 ольвійська монета - «борисфен», 1 монета Пантикапею, 1 монета Македонії); с. Оситняжка, Кропивницький p-н, Кіровоградська обл. (2 ольвійські монети - «борисфени», 1 монета Македонії), с. Родниківка, Олександрівська селищна громада, Кропивницький p-н, Кіровоградська обл. (1 ольвійська монета - «дихалк», 1 монета м. Кизік статер), м. Кропивницький (1 монета Перської держави Ахеменідів, 1 монета Македонії). Таким чином, нині автору відомо 19 населених пунктів, поблизу яких знайдено більше однієї монети (всього 47 монет), у тому числі 14 населених пунктів, поблизу яких виявлено 35 монет різних номіналів, періодів чи емітентів.

Щодо скарбів у басейні р. Тясмин, то науковій громадськості відомий скарб електрових литих статерів малоазійського міста, так званих кізікінів (13 одиниць, усі монети - VI ст. до н.е.), уведений до наукового обігу черкаським краєзнавцем А. Шостопалом*. Це розораний скарб, знайдений

\footnotetext{
* Ми вдячну А. Шостопалу за надані нам світлини 4 статерів та дозвіл на їх публікацію.
} 
випадково на полі у 2004 р. поблизу села с. Медведівка Черкаської обл. ${ }^{1}$. Даний скарб - перший з опублікованих дослідниками скарбів давньогрецьких монет. Другий опублікований скарб ${ }^{2}$ - це монетний комплекс із близько 70 мідних ольвійських монет - «борисфенів» (досліджено 52 монети), виявлених у квітні 2018 р. у межах лісового масиву на південно-східній околиці м. Городище Черкаської обл. на площі близько 5м2. Третій із відомих нам комплексів давньогрецьких монет, знайдених у басейні р. Тясмин, був виявлений наприкінці 2019 р. поблизу впадіння р. Бовтиш у р. Тясмин, (с. Івангород Кіровоградської обл.) $)^{3}$. Це розораний скарб «борисфенів», у складі якого виявлено 16 монет. Четвертий монетний комплекс знайдений у басейні р. Тясмин, інформацію про який автору повідомив один із чигиринських краєзнавців, це 11 ольвійських халків типу голова Тіхе у баштовій короні- схилений на одне коліно стрілець 3 лука вліво. Дані монети були виявлені поблизу с. Гненне (Чигиринська міська ОТГ, Черкаський р-н, Черкаська область).

Загалом увесь корпус знахідок монет VI-I ст. до н. е. у басейні р. Тясмин відповідно до типу знахідки наведено в таблиці 1.

Таблиця 1

\section{Розподіл знахідок давньогрецьких монет на території басейну р. Тясмин відповідно до типу знахідки}

\begin{tabular}{|l|c|c|}
\hline \multicolumn{1}{|c|}{ Тип знахідки: } & Кількість монет & \% \\
\hline Археологічні & 2 & 1,20 \\
\hline Випадкові: & & \\
\hline Одиничні знахідки & 26 & 15,57 \\
\hline \multicolumn{1}{|c|}{ Скупчення одиничних знахідок } & 47 & 28,14 \\
\hline Скарби: & 92 & 55,09 \\
\hline Разом & $\mathbf{1 6 7}$ & $\mathbf{1 0 0}$ \\
\hline
\end{tabular}

Таким чином, аналіз знахідок 167 античних монет VI-I ст. до н. е. на території басейну р. Тясмин дозволяє виокремити 23 пункти зосередження таких знахідок, зокрема 19 населених пунктів, поблизу яких знайдено більше однієї монети, і 4 населених пункти, поблизу яких виявлено монетні скарби (Рис.2).

Виявлення на території басейну р. Тясмин 23 пункту зі скупченням давньогрецьких монет, у тому числі 4 монетних скарбів, дозволяє висловити припущення про участь цих монет у товарно-грошових відносинах місцевого населення із греками, хоча зрозуміло, ці відносини не були настільки розвинутими, як у грецьких колоніях Північного Причорномор'я. Проте наявність знахідок даних монет на зазначених теренах пов'язується 3

\footnotetext{
${ }^{1}$ Шостопал 2007: 41.

${ }^{2}$ Орлик, Коцур \& Циганенко 2019.

${ }^{3}$ Орлик 2020-b.
} 
«виконанням монетами основних функцій грошей у досліджувану епоху на території Дніпровського Правобережного Лісостепу» ${ }^{1}$.

Усі знахідки свідчать про економічні, зокрема торгові, зв’язки населення басейну р. Тясмин 3 античним світом, який мав розвинутий грошовий обіг. Динаміку розвитку торгових зв’язків населення басейну р. Тясмин з античним світом ілюструють дані таблиці 2, у якій наводиться розподіл знахідок відповідно до їх емітентів.

Таблиця 2

Розподіл знахідок античних монет VI-I ст. до н. е. на території басейну р. Тясмин відповідно до їх емітентів

\begin{tabular}{|l|c|c|}
\hline \multirow{2}{*}{$\begin{array}{c}\text { Емітент } \\
\text { (місто/держава) }\end{array}$} & \multicolumn{2}{c|}{ Античні монети } \\
\cline { 2 - 3 } & Кількість & \% \\
\hline Ольвія & 125 & 74,86 \\
\hline Херсонес & 7 & 4,19 \\
\hline Пантикапей & 5 & 2,99 \\
\hline Керкінітида & 1 & 0,60 \\
\hline Мізія, м. Кизік & 14 & 8,38 \\
\hline Персія & 1 & 0,60 \\
\hline Істрія & 1 & 0,60 \\
\hline Македонія & 6 & 3,59 \\
\hline Віфінія (Вітінія) & 1 & 0,60 \\
\hline Понтійська держава & 6 & 3,59 \\
Мітрідата Евпатора & 6 & $\mathbf{1 0 0}$ \\
\hline Разом & $\mathbf{1 6 7}$ & \\
\hline
\end{tabular}

\section{Висновки дослідження.}

Як бачимо, майже 75 \% знахідок складають монети Ольвії, які за типами монет та періодами карбування поділяються на «дельфіни» (кінець VI - початок IV ст. до. н.е.) - 23 монети; «редуковані аси» (близько 400-380 рр. до. н.е.) 5 монет; 1 халк (400-370 рр. до н.е.); 1 дихалк (380-360 рр. до н.е.); 11 халків (360-350 pр. до н.е.); оболи з Деметрою та міською емблемою (350-330 pp. до н.е.) - 3 монети; 2 дрібні монети з головою Деметри (кінець IV ст. до. н.е.); «борисфени» (кінець IV - 20-ті роки III ст. до. н.е.) - 78 монет і 1 монета кінця III ст. до. н.е. Монети Херсонеса складають 4,19\% (4 монети IV ст. до. н.е., 2 початку III ст. до. н.е. та 1 монета середини I ст. до н.е.). Монети Пантікапею, які складають 2,99 \%, датовані кінцем IV ст. до. н.е. Така незначна кількість пантикапейських монет, знайдених у басейні р. Тясмин, порівняно зі знахідками ольвійських монет, дозволяє поставити під сумнів тезу про те, що «Ольвія у IV ст. до н.е. втратила провідну роль у торгівлі з варварами. Тепер вона належала Боспору» ${ }^{2}$. Навіть монети IV ст. до. н.е. далекої від Дніпровського

\footnotetext{
${ }^{1}$ Орлик 2020-b: 11.

2 Мурзін 1998: 86.
} 
Правобережного Лісостепу Македонії складають 3,59\%. Досить значний відсоток складають знахідки електрових статерів малоазійського міста Кизіка

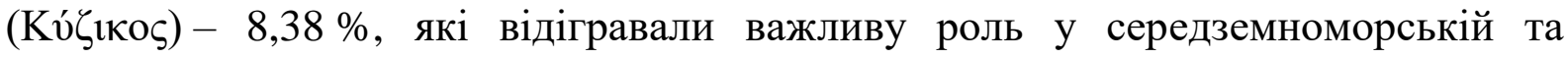
чорноморській торгівлі. Щодо монет, карбованих у ІІ ст. до. н.е., то відома лише одна знахідка в басейні р. Тясмин - монети правителя Віфінії (Вітініі) Прусія I Кульгавого, яка відповідає монетам, карбованим близько 228-182 рр. до н.е., тобто кінця III - початку II ст. до н.е. Практично, повна відсутність серед знахідок монет II ст. до. н.е. може свідчити на користь провідної ролі Ольвії у торгівлі з варварським населенням Дніпровського Правобережного Лісостепу, зокрема 3 населенням басейну р. Тясмин у попередній хронологічний період. Адже наприкінці III ст. до. н.е. Ольвія пережила скіро-галатську навалу, а II ст. до. н.е. було досить складним періодом у політичному та економічному житті цієї грецької колонії у Північно-Західному Причорномор’ї. Нумізматичні джерела, зокрема монетні знахідки, підтверджують тезу про те, що відносини Ольвії «з варварськими племенами Північного Причорномор'я скоротилися до мінімуму» ${ }^{1}$. Відновлення економічних зав'язків еллінів із населенням басейну р. Тясмин відбулося вже після входження Ольвії та інших грецьких колоній Північного Причорномор'я до складу Понтійської держави Мітрідата Євпатора, що підтверджують і монетні знахідки.

Достатня кількість нумізматичних джерел у культурних шарах поселень, у даному випадку монет давньогрецьких державних утворень, загублених свого часу їхніми власниками, свідчать про економічні, зокрема торгові, зв'язки населення басейну р. Тясмин 3 античним світом. Адже, як влучно зауважив класик української нумізматики Микола Котляр, монетні знахідки є «реліктами внутрішньої і зовнішньої торгівлі тих часів» ${ }^{2}$. I якщо одиничні знахідки можна було б віднести до випадкових, отже, не притаманних торговельним взаємовідносинам мешканців Дніпровського Правобережного Лісостепу в VIIII ст. до н. е., а також у I ст. до н. е., то тезаврація електрових та мідних монет як засобу накопичення засвідчує розвинені у цьому регіоні товарно-грошові відносини в досліджувану епоху. Таким чином, наявність виявлених скарбів та численних знахідок окремих монет, особливо скупчення одиничних знахідок на території басейну р. Тясмин, може вказувати на використання населенням цього регіону в VI-III ст. до н. е. а також у І ст. до н. е. тогочасних монет за їх основним призначенням - як засобу платежу чи накопичення, тобто на виконання цими монетами основних функцій грошей в досліджувану епоху на території Дніпровського Правобережного Лісостепу.

У II ст. до н. е. економічні зв'язки ольвіополітів із варварським світом були порушені, відповідно, монети, які зберігалися у місцевого населення, втратили свій грошовий характер, тому цілком можливо, що в цей період вони

\footnotetext{
${ }^{1}$ Крижицький 1998: 326.

${ }^{2}$ Котляр 1971: 65.
} 
функціонували не за своїм основним призначенням - бути засобом платежу, а могли використовуватися для виготовлення прикрас чи сировини.

Проаналізовані в даній статті знахідки античних монет VI-I ст. до н. е. на території басейну р. Тясмин - лише незначна частина всього корпусу подібних знахідок у даному регіоні, інформацію про які авторові вдалося виявити 3 різнопланових джерел, у тому числі й під час моніторингу аукціону Violity. Порушена нами проблема складна й багатогранна, вона потребує подальшого дослідження, перш за все необхідно виявити відомості про інші знахідки давньогрецьких монет в цьому та інших регіонах Дніпровського Правобережного Лісостепу. Автор запрошує до співпраці інших дослідників знахідок давньогрецьких монет на території Середньої Наддніпрянщини а також і на теренах більш західних регіонів Центральної Європи.

\section{КАТАЛОГ ЗНАХІДОК АНТИЧНИХ МОНЕТ VI-I СТ. ДО Н.Е. БАСЕЙНУ р. ТЯСМИН}

\begin{tabular}{|c|c|c|c|c|c|}
\hline No. & Опис & Датування & Опубліковано & $\begin{array}{l}\text { Bara / } \\
\text { poзмip }\end{array}$ & $\begin{array}{c}\text { Місце } \\
\text { і час знахідки } \\
\end{array}$ \\
\hline 1 & 2 & 3 & 4 & 5 & 6 \\
\hline 1 & $\begin{array}{c}\text { Ольвія, } \mathbf{A E} \\
\text { «дельфін» }\end{array}$ & $\begin{array}{c}\text { Кінець VI - початок } \\
\text { IV ст. до. н.е. } \\
\text { [Карышковский } \\
\text { 1988: 36] }\end{array}$ & Шостопал 2015 & Невідомо & $\begin{array}{c}\text { м. Сміла, } \\
\text { Черкаський р-н, } \\
\text { Черкаська обл. }\end{array}$ \\
\hline 2 & $\begin{array}{c}\text { Ольвія, } \mathbf{A E} \\
\text { «дельфін» }\end{array}$ & $\begin{array}{c}\text { Кінець VI - початок } \\
\text { IV ст. до. н.е. } \\
\text { [Карышковский } \\
\text { 1988: 36] }\end{array}$ & Шостопал 2015 & Невідомо & $\begin{array}{c}\text { с. Худяки, } \\
\text { Леськівська сільська } \\
\text { ОТГ, Черкаський р-н, } \\
\text { Черкаська обл. } \\
\end{array}$ \\
\hline 3 & $\begin{array}{c}\text { Ольвія, } \mathbf{A E} \\
\text { «дельфін» }\end{array}$ & $\begin{array}{c}\text { Кінець VI - початок } \\
\text { IV ст. до. н.е. } \\
\text { [Карышковский } \\
\text { 1988: 36] }\end{array}$ & $\begin{array}{c}\text { Скорый \& } \\
\text { Зимовец } 2014\end{array}$ & Невідомо & $\begin{array}{l}\text { с. Жаботин, урочище } \\
\text { Тарасова Криничка, } \\
\text { Михайлівська сільська } \\
\text { ОТГ, Черкаський р-н, } \\
\text { Черкаська обл., } 2009 \text { р. }\end{array}$ \\
\hline 4 & $\begin{array}{c}\text { Ольвія, } \mathbf{A E} \\
\text { «дельфін» }\end{array}$ & $\begin{array}{c}\text { Кінець VI - початок } \\
\text { IV ст. до. н.е. } \\
\text { [Карышковский } \\
\text { 1988: 36] }\end{array}$ & Шостопал 2015 & Невідомо & $\begin{array}{c}\text { с. Івківці, } \\
\text { Медведівська сільська } \\
\text { ОТГ, Черкаський р-н, } \\
\text { Черкаська обл. }\end{array}$ \\
\hline 5 & $\begin{array}{c}\text { Ольвія, } \mathbf{A E} \\
\text { «дельфін» } \\
\text { (див. Рис. 1.6) }\end{array}$ & $\begin{array}{c}\text { Кінець VI - початок } \\
\text { IV ст. до. н.е. } \\
\text { [Карышковский } \\
\text { 1988: 36] } \\
\end{array}$ & Шостопал 2007 & Невідомо & $\begin{array}{c}\text { с. Мельники, } \\
\text { Медведівська сільська } \\
\text { ОТГ, Черкаський р-н, } \\
\text { Черкаська обл., } 2003 \text { p. }{ }^{1}\end{array}$ \\
\hline 6 & $\begin{array}{c}\text { Ольвія, } \mathbf{A E} \\
\text { «дельфін» }\end{array}$ & $\begin{array}{c}\text { Кінець VI - початок } \\
\text { IV ст. до. н.е. } \\
\text { [Карышковский } \\
\text { 1988: 36] }\end{array}$ & Шостопал 2007 & Невідомо & $\begin{array}{c}\text { с. Мельники, } \\
\text { Медведівська сільська } \\
\text { ОТГ, Черкаський р-н, } \\
\text { Черкаська обл., } 2003 \text { р. }\end{array}$ \\
\hline 7 & $\begin{array}{c}\text { Ольвія, } \mathbf{A E} \\
\text { «дельфін» } \\
\text { Монета надломлена }\end{array}$ & $\begin{array}{c}\text { Кінець VI - початок } \\
\text { IV ст. до. н.е. } \\
\text { [Карышковский } \\
\text { 1988: 36] } \\
\end{array}$ & Шостопал 2007 & Невідомо & $\begin{array}{c}\text { с. Мельники, } \\
\text { Медведівська сільська } \\
\text { ОТГ, Черкаський р-н, } \\
\text { Черкаська обл., } 2004 \text { р. }\end{array}$ \\
\hline
\end{tabular}

1 Автор вдячний директору НІКЗ «Чигирин» к.і.н. Василю Полтавцю за надану інформацію та фотографію монети яка зберігається у фондах заповідника (інвентарний номер ЧНІКЗ КВ-10694/1Н4881). 
The Ukrainian Numismatic Annual. Issue 5, Pereiaslav, 2021.

\begin{tabular}{|c|c|c|c|c|c|}
\hline 1 & 2 & 3 & 4 & 5 & 6 \\
\hline 8 & $\begin{array}{c}\text { Ольвія, } \mathbf{A E} \\
\text { «дельфін» } \\
\text { (див. Рис. 1.1) }\end{array}$ & $\begin{array}{c}\text { Кінець VI - початок } \\
\text { IV ст. до. н.е. } \\
\text { [Карышковский } \\
\text { 1988: 36] }\end{array}$ & Шостопал 2015 & Невідомо & $\begin{array}{c}\text { с. Розсошинці, } \\
\text { Чигиринська міська } \\
\text { ОТГ, Черкаський р-н, } \\
\text { Черкаська обл., } 2011 \text { p. }{ }^{1}\end{array}$ \\
\hline 9 & $\begin{array}{c}\text { Ольвія, } \mathbf{A E} \\
\text { «дельфін» } \\
\text { (див. Рис. 1.2) }\end{array}$ & $\begin{array}{c}\text { Кінець VI - початок } \\
\text { IV ст. до. н.е. } \\
\text { [Карышковский } \\
\text { 1988: 36] }\end{array}$ & Шостопал 2015 & Невідомо & $\begin{array}{c}\text { с. Розсошинці, } \\
\text { Чигиринська міська } \\
\text { ОТГ, Черкаський р-н, } \\
\text { Черкаська обл., } 2011 \text { р. }\end{array}$ \\
\hline 10 & $\begin{array}{c}\text { Ольвія, } \mathbf{A E} \\
\text { «дельфін» } \\
\text { (див. Рис. 1.3) }\end{array}$ & $\begin{array}{c}\text { Кінець VI - початок } \\
\text { IV ст. до. н.е. } \\
\text { [Карышковский } \\
\text { 1988: 36] }\end{array}$ & Шостопал 2015 & Невідомо & $\begin{array}{c}\text { с. Розсошинці, } \\
\text { Чигиринська міська } \\
\text { ОТГ, Черкаський р-н, } \\
\text { Черкаська обл., } 2011 \text { р. }\end{array}$ \\
\hline 11 & $\begin{array}{c}\text { Ольвія, } \mathbf{A E} \\
\text { «дельфін» } \\
\text { (див. Рис. 1.4) }\end{array}$ & $\begin{array}{c}\text { Кінець VI - початок } \\
\text { IV ст. до. н.е. } \\
\text { [Карышковский } \\
\text { 1988: 36] }\end{array}$ & Шостопал 2015 & Невідомо & $\begin{array}{c}\text { с. Розсошинці, } \\
\text { Чигиринська міська } \\
\text { ОТГ, Черкаський р-н, } \\
\text { Черкаська обл., } 2011 \text { р. }\end{array}$ \\
\hline 12 & $\begin{array}{c}\text { Ольвія, } \mathbf{A E} \\
\text { «дельфін» } \\
\text { (див. Рис. 1.5) }\end{array}$ & $\begin{array}{c}\text { Кінець VI - початок } \\
\text { IV ст. до. н.е. [ 36] }\end{array}$ & Шостопал 2015 & Невідомо & $\begin{array}{c}\text { с. Розсошинці, } \\
\text { Чигиринська міська } \\
\text { ОТГ, Черкаський р-н, } \\
\text { Черкаська обл., } 2011 \text { р. }\end{array}$ \\
\hline 13 & $\begin{array}{c}\text { Ольвія, } \mathbf{A E} \\
\text { «дельфін» }\end{array}$ & $\begin{array}{c}\text { Кінець VI - початок } \\
\text { IV ст. до. н.е. } \\
\text { [Карышковский } \\
\text { 1988: 36] }\end{array}$ & Шостопал 2015 & Невідомо & $\begin{array}{c}\text { с. Розсошинці, } \\
\text { Чигиринська міська } \\
\text { ОТГ, Черкаський р-н, } \\
\text { Черкаська обл., } 2011 \text { р. }\end{array}$ \\
\hline 14 & $\begin{array}{c}\text { Ольвія, } \mathbf{A E} \\
\text { «дельфін» }\end{array}$ & $\begin{array}{l}\text { Кінець VI - початок } \\
\text { IV ст. до. н.е. } \\
\text { [Карышковский } 1988 \\
\text {, 36] }\end{array}$ & Шостопал 2015 & Невідомо & $\begin{array}{c}\text { с. Розсошинці, } \\
\text { Чигиринська міська } \\
\text { ОТГ, Черкаський р-н, } \\
\text { Черкаська обл., } 2011 \text { р. }\end{array}$ \\
\hline 15 & $\begin{array}{c}\text { Ольвія, } \mathbf{A E} \\
\text { «дельфін» }\end{array}$ & $\begin{array}{c}\text { Кінець VI - початок } \\
\text { IV ст. до. н.е. } \\
\text { [Карышковский } \\
\text { 1988: 36] }\end{array}$ & Шостопал 2015 & Невідомо & $\begin{array}{c}\text { с. Розсошинці, } \\
\text { Чигиринська міська } \\
\text { ОТГ, Черкаський р-н, } \\
\text { Черкаська обл., } 2011 \text { р. }\end{array}$ \\
\hline 16 & $\begin{array}{c}\text { Ольвія, } \mathbf{A E} \\
\text { «дельфін» }\end{array}$ & $\begin{array}{c}\text { Кінець VI - початок } \\
\text { IV ст. до. н.е. } \\
\text { [Карышковский } \\
\text { 1988: 36] }\end{array}$ & Шостопал 2015 & Невідомо & $\begin{array}{c}\text { с. Новоселиця, } \\
\text { Чигиринська міська } \\
\text { ОТГ, Черкаський р-н, } \\
\text { Черкаська обл. }\end{array}$ \\
\hline 17 & $\begin{array}{c}\text { Ольвія, } \mathbf{A E} \\
\text { «дельфін» }\end{array}$ & $\begin{array}{c}\text { Кінець VI - початок } \\
\text { IV ст. до. н.е. } \\
\text { [Карышковский } \\
\text { 1988: 36] }\end{array}$ & Шостопал 2015 & Невідомо & $\begin{array}{l}\text { с. Суботів, Чигиринська } \\
\text { міська ОТГ, Черкаський } \\
\text { р-н, Черкаська обл. }\end{array}$ \\
\hline 18 & $\begin{array}{c}\text { Ольвія, } \mathbf{A E} \\
\text { «дельфін» }\end{array}$ & $\begin{array}{c}\text { Кінець VI - початок } \\
\text { IV ст. до. н.е. } \\
\text { [Карышковский } \\
\text { 1988: 36] }\end{array}$ & Шостопал 2015 & Невідомо & $\begin{array}{c}\text { с. Іванівка, Чигиринська } \\
\text { міська ОТГ, Черкаський } \\
\text { p-н, Черкаська обл. }\end{array}$ \\
\hline 19 & $\begin{array}{c}\text { Ольвія, } \mathbf{A E} \\
\text { «дельфін» }\end{array}$ & $\begin{array}{c}\text { Кінець VI - початок } \\
\text { IV ст. до. н.е. } \\
\text { [Карышковский } \\
\text { 1988: 36] }\end{array}$ & Шостопал 2015 & Невідомо & $\begin{array}{c}\text { с. Бурякове, } \\
\text { Чигиринська міська } \\
\text { ОТГ, Черкаський р-н, } \\
\text { Черкаська обл. }\end{array}$ \\
\hline 20 & $\begin{array}{c}\text { Ольвія, } \mathbf{A E} \\
\text { «дельфін» }\end{array}$ & $\begin{array}{c}\text { Кінець VI - початок } \\
\text { IV ст. до. н.е. } \\
\text { [Карышковский } \\
\text { 1988: 36] }\end{array}$ & $\begin{array}{c}\text { Не } \\
\text { опубліковано }\end{array}$ & Невідомо & $\begin{array}{l}\text { Між селами Голиківка, } \\
\text { Медведівська сільська } \\
\text { ОТГ, Черкаський р-н, } \\
\text { Черкаська обл. i } \\
\text { Поселянівка, } \\
\text { Олександрівська } \\
\text { селищна громада, } \\
\text { Кропивницький р-н, } \\
\text { Кіровоградська обл. }\end{array}$ \\
\hline
\end{tabular}

\footnotetext{
${ }^{1}$ Автор вдячний Анатолію Шостопалу за надані світлини монет.
} 
Украӥнський нумізматичний щорічник. Вип. 5. Переяслав, 2021.

\begin{tabular}{|c|c|c|c|c|c|}
\hline 1 & 2 & 3 & 4 & 5 & 6 \\
\hline 21 & $\begin{array}{c}\text { Ольвія, } \mathbf{A E} \\
\text { «дельфін» } \\
\text { (див. Рис. 1.7) }\end{array}$ & $\begin{array}{c}\text { Кінець VI - початок } \\
\text { IV ст. до. н.е. } \\
\text { [Карышковский } \\
\text { 1988: 36] }\end{array}$ & $\begin{array}{c}\text { Не } \\
\text { опубліковано }\end{array}$ & Невідомо & $\begin{array}{l}\text { Між селами Голиківка, } \\
\text { Медведівська сільська } \\
\text { ОТГ, Черкаський р-н, } \\
\text { Черкаська обл. і } \\
\text { Поселянівка, } \\
\text { Олександрівська } \\
\text { селищна громада, } \\
\text { Кропивницький р-н, } \\
\text { Кіровоградська обл. }\end{array}$ \\
\hline 22 & $\begin{array}{c}\text { Ольвія, } \mathbf{A E} \\
\text { «дельфін» }\end{array}$ & $\begin{array}{c}\text { Кінець VI - початок } \\
\text { IV ст. до. н.е. } \\
\text { [Карышковский } \\
\text { 1988: 36] }\end{array}$ & $\begin{array}{c}\text { Орлик 2014; } \\
\text { Скорый \& } \\
\text { Зимовец } 2014\end{array}$ & $\begin{array}{l}\text { Невідомо } \\
35 \text { мм. }\end{array}$ & $\begin{array}{c}\text { с. Іванівка, } \\
\text { Олександрівська } \\
\text { селищна громада, } \\
\text { Кропивницький р-н, } \\
\text { Кіровоградська обл., } \\
2012 \text { р. } \\
\end{array}$ \\
\hline 23 & $\begin{array}{c}\text { Ольвія, } \mathbf{A E} \\
\text { «дельфін» }\end{array}$ & $\begin{array}{c}\text { Кінець VI - початок } \\
\text { IV ст. до. н.е. } \\
\text { [Карышковский } \\
\text { 1988: 36] }\end{array}$ & $\begin{array}{c}\text { Не } \\
\text { опубліковано }\end{array}$ & Невідомо & $\begin{array}{c}\text { с. Михайлівка, } \\
\text { Олександрівська } \\
\text { селищна громада, } \\
\text { Кропивницький р-н, } \\
\text { Кіровоградська обл. }\end{array}$ \\
\hline 24 & $\begin{array}{c}\text { Ольвія, } \mathbf{A E} \\
\text { Av: Голова Горгони без } \\
\text { язика в анфас } \\
\text { Rv: Орел на дельфіні } \\
\text { вліво, літери } \Lambda \text { і В між } \\
\text { хвостами орла та } \\
\text { дельфіна } \\
\text { (див. Рис. } 1.8 \text { ) } \\
\end{array}$ & $\begin{array}{l}\text { Близько 400-380 pp. } \\
\text { до. н.е. } \\
\text { [Анохин 2011: \#184] }\end{array}$ & forum.violity & $\begin{array}{l}17,7 \text { г. } \\
36 \text { мм. }\end{array}$ & $\begin{array}{c}\text { с. Гненне, Чигиринська } \\
\text { міська ОТГ, Черкаський } \\
\text { р-н, Черкаська обл., } \\
2015\end{array}$ \\
\hline 25 & $\begin{array}{c}\text { Ольвія, } \mathbf{A E} \\
\text { Av: Голова Горгони в } \\
\text { анфас } \\
\text { Rv: Орел на дельфіні } \\
\text { вліво } \\
\end{array}$ & $\begin{array}{c}\text { Близько 400-380 pp. } \\
\text { до. н.е. } \\
\text { [Анохин 2011: \#185- } \\
\text { 187] }\end{array}$ & $\begin{array}{c}\text { Не } \\
\text { опубліковано }\end{array}$ & Невідомо & $\begin{array}{c}\text { с. Макіївка, } \\
\text { Ротмістрівська сільська } \\
\text { ОТГ, Черкаський р-н, } \\
\text { Черкаська обл. } \\
\text { До } 2019 \text { р. } \\
\end{array}$ \\
\hline 26 & $\begin{array}{c}\text { Ольвія, } \mathbf{A E} \\
\text { Av: Голова Горгони в } \\
\text { анфас } \\
\text { Rv: Орел на дельфіні } \\
\text { вліво } \\
\end{array}$ & $\begin{array}{c}\text { Близько 400-380 pр. } \\
\text { до. н.е. } \\
\text { [Анохин 2011: \#185- } \\
\text { 187] }\end{array}$ & Ляшко 2017-а & $\begin{array}{l}15,2 \text { г. } \\
35 \text { мм. }\end{array}$ & $\begin{array}{c}\text { с. Райгород, } \\
\text { Михайлівська сільська } \\
\text { ОТГ, Черкаський р-н, } \\
\text { Черкаська обл. } \\
2017 \text { р. } \\
\end{array}$ \\
\hline 27 & $\begin{array}{c}\text { Ольвія, } \mathbf{A E} \\
\text { Av: Голова Горгони в } \\
\text { анфас } \\
\text { Rv: Орел на дельфіні } \\
\text { вліво } \\
\text { (див. Рис. 1.9) }\end{array}$ & $\begin{array}{c}\text { Близько 400-380 } \\
\text { pр. до. н.е. } \\
\text { [Анохин 2011: } \\
\# 185-187]\end{array}$ & $\begin{array}{c}\text { Не } \\
\text { опубліковано }\end{array}$ & Невідомо & $\begin{array}{c}\text { Між селами } \\
\text { Капітанівка, } \\
\text { Новомиргородська } \\
\text { міська громада, } \\
\text { Новоукраїнський р-н, } \\
\text { Кіровоградська обл. та } \\
\text { Пастирське, Тернїська } \\
\text { сільська ОТГ, } \\
\text { Черкаський р-н, } \\
\text { Черкаська обл., на межі } \\
\text { областей, } \\
2021 \text { р. } \\
\end{array}$ \\
\hline 28 & $\begin{array}{c}\text { Ольвія, } \mathbf{A E} \\
\text { Av: Голова Горгони в } \\
\text { анфас } \\
\text { Rv: Орел на дельфіні } \\
\text { вліво }\end{array}$ & $\begin{array}{c}\text { Близько 400-380 } \\
\text { рр. до. н.е. } \\
\text { [Анохин 2011: } \\
\# 185-187]\end{array}$ & $\begin{array}{c}\text { Не } \\
\text { опубліковано }\end{array}$ & Невідомо & $\begin{array}{c}\text { Між селами Калинівка } \\
\text { та Веселий Кут } \\
\text { Дмитрівська сільська } \\
\text { громада, } \\
\text { Кропивницький р-н, } \\
\text { Кіровоградська обл. } \\
\end{array}$ \\
\hline 29 & $\begin{array}{c}\text { Ольвія, АE } \\
\text { Av: Голова Деметри } \\
\text { вправо. } \\
\text { Rv: Вгорі ОАВІО, нижче } \\
\text { колос і дельфін вправо, } \\
\text { внизу ФОВ } \\
\text { (див. Рис. } 1.10) \\
\end{array}$ & $\begin{array}{c}\text { Близько 400-370 } \\
\text { pp. до. н.е. } \\
\text { [Нечитайло 2000: } \\
\text { \#136] }\end{array}$ & forum.violity & $\begin{array}{l}1,62 \text { г. } \\
14 \text { мм. }\end{array}$ & $\begin{array}{c}\text { с. Цибулеве, } \\
\text { Дмитрівська сільська } \\
\text { громада, } \\
\text { Кропивницький р-н, } \\
\text { Кіровоградська обл. }\end{array}$ \\
\hline
\end{tabular}


The Ukrainian Numismatic Annual. Issue 5, Pereiaslav, 2021.

\begin{tabular}{|c|c|c|c|c|c|}
\hline 1 & 2 & 3 & 4 & 5 & 6 \\
\hline 30 & $\begin{array}{c}\text { Ольвія, АE } \\
\text { Av: Голова Деметри } \\
\text { вправо. } \\
\text { Rv: Вгорі ОАВIО, нижче } \\
\text { орел дельфін вправо }\end{array}$ & $\begin{array}{c}\text { 380-360 рр. до. н.е. } \\
\text { [Анохин 2011] }\end{array}$ & $\begin{array}{c}\text { Не } \\
\text { опубліковано }\end{array}$ & $\begin{array}{l}4,06 \text { г. } \\
18 \text { мм. }\end{array}$ & $\begin{array}{c}\text { с. Родниківка, } \\
\text { Олександрівська } \\
\text { селищна громада, } \\
\text { Кропивницький р-н, } \\
\text { Кіровоградська обл., } \\
2021 \text { р. }\end{array}$ \\
\hline 31 & $\begin{array}{c}\text { Ольвія, } \mathbf{A E} \\
\text { Av: Голова Tixe у } \\
\text { баштовій короні } \\
\text { Rv: Стрілець з лука вліво, } \\
\text { схилений на одне коліно }\end{array}$ & $\begin{array}{l}360-350 \mathrm{pp} . \\
\text { [Анохин 2011: } \\
\text { \#226-231] }\end{array}$ & $\begin{array}{c}\text { Не } \\
\text { опубліковано }\end{array}$ & Невідомо & $\begin{array}{c}\text { с. Гненне, Чигиринська } \\
\text { міська ОТГ, Черкаський } \\
\text { p-н, Черкаська обл. }{ }^{1}\end{array}$ \\
\hline 32 & $\begin{array}{c}\text { Ольвія, } \mathbf{A E} \\
\text { Av: Голова Tixe у } \\
\text { баштовій короні } \\
\text { Rv: Стрілець з лука вліво, } \\
\text { схилений на одне коліно }\end{array}$ & $\begin{array}{l}360-350 \mathrm{pp} . \\
\text { [Анохин 2011: } \\
\text { \#226-231] }\end{array}$ & $\begin{array}{c}\mathrm{He} \\
\text { опубліковано }\end{array}$ & Невідомо & $\begin{array}{c}\text { с. Гненне, Чигиринська } \\
\text { міська ОТГ, Черкаський } \\
\text { р-н, Черкаська обл. }\end{array}$ \\
\hline 33 & $\begin{array}{c}\text { Ольвія, } \mathbf{A E} \\
\text { Av: Голова Tixe у } \\
\text { баштовій короні } \\
\text { Rv: Стрілець з лука вліво, } \\
\text { схилений на одне коліно }\end{array}$ & $\begin{array}{l}360-350 \mathrm{pp} . \\
\text { [Анохин 2011: } \\
\text { \#226-231] }\end{array}$ & $\begin{array}{c}\mathrm{He} \\
\text { опубліковано }\end{array}$ & Невідомо & $\begin{array}{c}\text { с. Гненне, Чигиринська } \\
\text { міська ОТГ, Черкаський } \\
\text { p-н, Черкаська обл. }\end{array}$ \\
\hline 34 & $\begin{array}{c}\text { Ольвія, } \mathbf{A E} \\
\text { Av: Голова Tixe у } \\
\text { баштовій короні } \\
\text { Rv: Стрілець з лука вліво, } \\
\text { схилений на одне коліно } \\
\end{array}$ & $\begin{array}{l}360-350 \mathrm{pp} . \\
\text { [Анохин 2011: } \\
\text { \#226-231] }\end{array}$ & $\begin{array}{c}\text { Не } \\
\text { опубліковано }\end{array}$ & Невідомо & $\begin{array}{c}\text { с. Гненне, Чигиринська } \\
\text { міська ОТГ, Черкаський } \\
\text { р-н, Черкаська обл. }\end{array}$ \\
\hline 35 & $\begin{array}{c}\text { Ольвія, } \mathbf{A E} \\
\text { Av: Голова Tixe у } \\
\text { баштовій короні } \\
\text { Rv: Стрілець з лука вліво, } \\
\text { схилений на одне коліно }\end{array}$ & $\begin{array}{l}360-350 \mathrm{pp} . \\
\text { [Анохин 2011: } \\
\text { \#226-231] }\end{array}$ & $\begin{array}{c}\text { Не } \\
\text { опубліковано }\end{array}$ & Невідомо & $\begin{array}{c}\text { с. Гненне, Чигиринська } \\
\text { міська ОТГ, Черкаський } \\
\text { р-н, Черкаська обл. }\end{array}$ \\
\hline 36 & $\begin{array}{c}\text { Ольвія, } \mathbf{A E} \\
\text { Av: Голова Tixe у } \\
\text { баштовій короні } \\
\text { Rv: Стрілець з лука вліво, } \\
\text { схилений на одне коліно }\end{array}$ & $\begin{array}{l}360-350 \mathrm{pp} . \\
\text { [Анохин 2011: } \\
\text { \#226-231] }\end{array}$ & $\begin{array}{c}\text { Не } \\
\text { опубліковано }\end{array}$ & Невідомо & $\begin{array}{c}\text { с. Гненне, Чигиринська } \\
\text { міська ОТГ, Черкаський } \\
\text { р-н, Черкаська обл. }\end{array}$ \\
\hline 37 & $\begin{array}{c}\text { Ольвія, } \mathbf{A E} \\
\text { Av: Голова Тіхе у } \\
\text { баштовій короні } \\
\text { Rv: Стрілець з лука вліво, } \\
\text { схилений на одне коліно } \\
\end{array}$ & $\begin{array}{l}360-350 \mathrm{pp} . \\
\text { [Анохин 2011: } \\
\text { \#226-231] }\end{array}$ & $\begin{array}{c}\text { Не } \\
\text { опубліковано }\end{array}$ & Невідомо & $\begin{array}{c}\text { с. Гненне, Чигиринська } \\
\text { міська ОТГ, Черкаський } \\
\text { р-н, Черкаська обл. }\end{array}$ \\
\hline 38 & $\begin{array}{c}\text { Ольвія, } \mathbf{A E} \\
\text { Av: Голова Tixe у } \\
\text { баштовій короні } \\
\text { Rv: Стрілець з лука вліво, } \\
\text { схилений на одне коліно }\end{array}$ & $\begin{array}{l}360-350 \mathrm{pp} . \\
\text { [Анохин 2011: } \\
\text { \#226-231] }\end{array}$ & $\begin{array}{c}\text { Не } \\
\text { опубліковано }\end{array}$ & Невідомо & $\begin{array}{c}\text { с. Гненне, Чигиринська } \\
\text { міська ОТГ, Черкаський } \\
\text { р-н, Черкаська обл. }\end{array}$ \\
\hline 39 & $\begin{array}{c}\text { Ольвія, } \mathbf{A E} \\
\text { Av: Голова Tixe у } \\
\text { баштовій короні } \\
\text { Rv: Стрілець з лука вліво, } \\
\text { схилений на одне коліно }\end{array}$ & $\begin{array}{l}360-350 \mathrm{pp} . \\
\text { [Анохин 2011: } \\
\text { \#226-231] }\end{array}$ & $\begin{array}{c}\mathrm{He} \\
\text { опубліковано }\end{array}$ & Невідомо & $\begin{array}{c}\text { с. Гненне, Чигиринська } \\
\text { міська ОТГ, Черкаський } \\
\text { p-н, Черкаська обл. }\end{array}$ \\
\hline 40 & $\begin{array}{c}\text { Ольвія, } \mathbf{A E} \\
\text { Av: Голова Tixe у } \\
\text { баштовій короні } \\
\text { Rv: Стрілець з лука вліво, } \\
\text { схилений на одне коліно } \\
\end{array}$ & $\begin{array}{l}360-350 \mathrm{pp} . \\
\text { [Анохин 2011: } \\
\text { \#226-231] }\end{array}$ & $\begin{array}{c}\text { Не } \\
\text { опубліковано }\end{array}$ & Невідомо & $\begin{array}{c}\text { с. Гненне, Чигиринська } \\
\text { міська ОТГ, Черкаський } \\
\text { p-н, Черкаська обл. }\end{array}$ \\
\hline 41 & $\begin{array}{c}\text { Ольвія, } \mathbf{A E} \\
\text { Av: Голова Tixe у } \\
\text { баштовій короні } \\
\text { Rv: Стрілець } 3 \text { лука вліво, } \\
\text { схилений на одне коліно } \\
\end{array}$ & $\begin{array}{l}360-350 \mathrm{pp} . \\
\text { [Анохин 2011: } \\
\text { \#226-231] }\end{array}$ & $\begin{array}{c}\text { Не } \\
\text { опубліковано }\end{array}$ & Невідомо & $\begin{array}{c}\text { с. Гненне, Чигиринська } \\
\text { міська ОТГ, Черкаський } \\
\text { р-н, Черкаська обл. }\end{array}$ \\
\hline
\end{tabular}

\footnotetext{
${ }^{1}$ Протягом 2011-2021 років, за інформацією одного із чигиринських краєзнавців, на одному місці було знайдено більше 11 таких монет. Враховуючи, той факт, що усі монети одного типу і знайдені в одному місці, на думку автора це розораний монетний комплекс.
} 
Украӥнський нумізматичний щорічник. Вип. 5. Переяслав, 2021.

\begin{tabular}{|c|c|c|c|c|c|}
\hline 1 & 2 & 3 & 4 & 5 & 6 \\
\hline 42 & $\begin{array}{c}\text { Ольвія, } \mathbf{A E} \\
\text { Av: Голова Деметри вліво. } \\
\text { Rv: Вгорі АПО } \Lambda, \text { орел на } \\
\text { дельфіні вліво, праворуч - } \\
\text { горит, ОАВІО - під } \\
\text { дельфіном } \\
\text { (див. Рис. } 1.11 \text { ) }\end{array}$ & $\begin{array}{c}\text { 350-330 рр. до. н.е. } \\
\text { [Карышковский } \\
\text { 1988]. } \\
\text { 340-320 рр. до. н.е. } \\
\text { [Фролова \& } \\
\text { Абрамзон 2005]. } \\
\text { Близько } 330 \text { р. до. } \\
\text { н.е. [Анохин 2011] }\end{array}$ & Орлик 2020-с & $\begin{array}{c}\text { 9,51 г. } \\
22,5 \text { мм. }\end{array}$ & $\begin{array}{c}\text { с. Розумівка, } \\
\text { Олександрівська } \\
\text { селищна громада, } \\
\text { Кіровоградська обл., } \\
2019 \text { р. }\end{array}$ \\
\hline 43 & $\begin{array}{c}\text { Ольвія, } \mathbf{A E} \\
\text { Av: Голова Деметри вліво. } \\
\text { Rv: Вгорі } \Delta(\text { можливо } \Sigma) \\
<\ldots>, \text { орел на дельфіні } \\
\text { вліво, праворуч - горит, } \\
\text { ОАВІО - під дельфіном } \\
\text { (див. Рис. } 1.12)\end{array}$ & $\begin{array}{c}\text { 350-330 рр. до. н.е. } \\
\text { [Карышковский } 19 \\
88] . \\
\text { 340-320 рр. до. н.е. } \\
\text { [Фролова \& } \\
\text { Абрамзон 2005]. } \\
\text { Близько } 330 \text { р. до. } \\
\text { н.е. [Анохин 2011] }\end{array}$ & Орлик 2020-с & $\begin{array}{l}7,93 \text { г. } \\
22 \text { мм. }\end{array}$ & $\begin{array}{l}\text { Чигиринська міська } \\
\text { ОТГ, Черкаський р-н, } \\
\text { Черкаська обл. } 2020 \text { p. }\end{array}$ \\
\hline 44 & $\begin{array}{c}\text { Ольвія, } \mathbf{A E} \\
\text { Av: Голова Деметри вліво. } \\
\text { Rv: Вгорі } \Delta(\text { можливо } \Sigma) \\
\text { <..>, орел на дельфіні } \\
\text { вліво, праворуч - горит, } \\
\text { ОАВІО - під дельфіном } \\
\text { (див. Рис. } 1.13)\end{array}$ & $\begin{array}{c}\text { 350-330 рр. до. н.е. } \\
\text { [Карышковский } 19 \\
88] . \\
\text { 340-320 рр. до. н.е. } \\
\text { [Фролова \& } \\
\text { Абрамзон 2005]. } \\
\text { Близько } 330 \text { р. до. } \\
\text { н.е. [Анохин 2011] }\end{array}$ & $\begin{array}{c}\text { Не } \\
\text { опубліковано }\end{array}$ & $\begin{array}{l}9,85 \text { г. } \\
24 \text { мм. }\end{array}$ & $\begin{array}{c}\text { с. Вдовичине, } \\
\text { Чигиринська міська } \\
\text { ОТГ, Черкаський р-н, } \\
\text { Черкаська обл. } 2020 \text { p. }{ }^{1}\end{array}$ \\
\hline 45 & $\begin{array}{c}\text { Ольвія, АE } \\
\text { Av: Голова Деметри } \\
\text { Rv: Орел на дельфіні }\end{array}$ & $\begin{array}{l}320-315 \mathrm{pp} . \\
\text { [Анохин 2011: } \\
\text { \#288-289] }\end{array}$ & $\begin{array}{c}\text { Не } \\
\text { опубліковано }\end{array}$ & Невідомо & $\begin{array}{c}\text { с. Михайлівка, } \\
\text { Олександрівська } \\
\text { селищна громада, } \\
\text { Кропивницький р-н, } \\
\text { Кіровоградська обл. }\end{array}$ \\
\hline 46 & $\begin{array}{c}\text { Ольвія, АE } \\
\text { Av: Голова Деметри } \\
\text { Rv: Орел на дельфіні }\end{array}$ & $\begin{array}{l}320-315 \mathrm{pp} . \\
\text { [Анохин 2011: } \\
\text { \#288-289] }\end{array}$ & $\begin{array}{c}\text { Не } \\
\text { опубліковано }\end{array}$ & Невідомо & $\begin{array}{c}\text { с. Цибулеве, } \\
\text { Дмитрівська сільська } \\
\text { громада, } \\
\text { Кропивницький р-н, } \\
\text { Кіровоградська обл. }\end{array}$ \\
\hline 47 & $\begin{array}{c}\text { Ольвія, АE } \\
\text { Av: Голова Борисфена } \\
\text { (річкового божества) } \\
\text { вліво. } \\
\text { Rv: } 3 \text { права напис ОАВІО, } \\
\text { по центру поля монети } \\
\text { горит, зліва від нього } \\
\text { парадна сокира за нею } \\
\text { диферент \#4 } \\
\text { (див. Рис. 1.14) } \\
\end{array}$ & $\begin{array}{l}328 \text { р. до. н.е. } \\
\text { [Ніколаєв 2020: } \\
\text { 39]. }\end{array}$ & $\begin{array}{c}\text { Не } \\
\text { опубліковано }\end{array}$ & $\begin{array}{l}10,83 \text { г. } \\
22 \text { мм. }\end{array}$ & $\begin{array}{c}\text { с. Макіївка, } \\
\text { Ротмістрівська сільська } \\
\text { ОТГ, Черкаський р-н, } \\
\text { Черкаська обл., } \\
2020 \text { р. }\end{array}$ \\
\hline 48 & $\begin{array}{c}\text { Ольвія, АE } \\
\text { Av: Голова Борисфена } \\
\text { (річкового божества) } \\
\text { вліво. } \\
\text { Rv: } 3 \text { права напис ОАВІО, } \\
\text { по центру поля монети } \\
\text { горит, зліва від нього } \\
\text { парадна сокира за нею } \\
\text { диферент \#9 } \\
\text { (див. Рис. } 1.15 \text { ) } \\
\end{array}$ & $\begin{array}{l}326 \text { р. до. н.е. } \\
\text { [Ніколаєв 2020: } \\
\text { 39]. }\end{array}$ & auction.violity & $\begin{array}{l}9,41 г \text {. } \\
19 \times 21 \\
\text { мм. }\end{array}$ & $\begin{array}{c}\text { с. Ковалиха, } \\
\text { Ротмістрівська сільська } \\
\text { ОТГ, Черкаський р-н, } \\
\text { Черкаська обл. } 2018 \text { р. }\end{array}$ \\
\hline 49 & $\begin{array}{c}\text { Ольвія, АE } \\
\text { Av: Голова Борисфена } \\
\text { (річкового божества) } \\
\text { вліво. } \\
\text { Rv: } 3 \text { права напис ОАВІО, } \\
\text { по центру поля монети } \\
\text { горит, зліва від нього } \\
\text { парадна сокира за нею } \\
\text { диферент \#14 }\end{array}$ & $\begin{array}{l}319 \text { р. до. н.е. } \\
\text { [Ніколаєв 2020: } \\
\text { 39]. }\end{array}$ & $\begin{array}{c}\text { Не } \\
\text { опубліковано }\end{array}$ & $\begin{array}{l}7,53 \text { г. } \\
22 \text { мм. }\end{array}$ & $\begin{array}{c}\text { Між селами с. } \\
\text { Оситняжка та } \\
\text { Родниківка, } \\
\text { Кропивницький р-н, } \\
\text { Кіровоградська обл., } \\
\text { вздовж р.Інгул. }\end{array}$ \\
\hline
\end{tabular}

${ }^{1}$ Автор вдячний Євгену Колісніченку за надану інформацію та світлину монети. 
The Ukrainian Numismatic Annual. Issue 5, Pereiaslav, 2021.

\begin{tabular}{|c|c|c|c|c|c|}
\hline 1 & 2 & 3 & 4 & 5 & 6 \\
\hline 50 & $\begin{array}{c}\text { Ольвія, АE } \\
\text { Av: Голова Борисфена } \\
\text { (річкового божества) } \\
\text { вліво. } \\
\text { Rv: } 3 \text { права напис ОАВІО, } \\
\text { по центру поля монети } \\
\text { горит, зліва від нього } \\
\text { парадна сокира за нею } \\
\text { диферент \#16 }\end{array}$ & $\begin{array}{l}306 \text { р. до. н.е. } \\
\text { [Ніколаєв 2020: } \\
\text { 39]. }\end{array}$ & $\begin{array}{c}\text { Орлик, Коцур } \\
\& \text { Циганенко } \\
2019\end{array}$ & $\begin{array}{l}10,00 \text { г. } \\
22 \text { мм. }\end{array}$ & $\begin{array}{l}\text { м.Городище, } \\
\text { Черкаський р-н, } \\
\text { Черкаська обл., } \\
2018 \text { р. }\end{array}$ \\
\hline 51 & $\begin{array}{c}\text { Ольвія, АE } \\
\text { Av: Голова Борисфена } \\
\text { (річкового божества) } \\
\text { вліво. } \\
\text { Rv: } 3 \text { права напис ОАВІО, } \\
\text { по центру поля монети } \\
\text { горит, зліва від нього } \\
\text { парадна сокира за нею } \\
\text { диферент \#20 } \\
\text { (див. Рис. 1.16) } \\
\end{array}$ & $\begin{array}{l}302 \text { р. до. н.е. } \\
\text { [Ніколаєв 2020: } \\
\text { 39]. }\end{array}$ & $\begin{array}{c}\text { Орлик, Коцур } \\
\text { \& Циганенко } \\
2019\end{array}$ & $\begin{array}{l}10,00 \text { г. } \\
23 \text { мм. }\end{array}$ & $\begin{array}{l}\text { м.Городище, } \\
\text { Черкаський р-н, } \\
\text { Черкаська обл., } \\
2018 \text { р. }\end{array}$ \\
\hline 52 & $\begin{array}{c}\text { Ольвія, АE } \\
\text { Av: Голова Борисфена } \\
\text { (річкового божества) } \\
\text { вліво. } \\
\text { Rv: } 3 \text { права напис ОАВІО, } \\
\text { по центру поля монети } \\
\text { горит, зліва від нього } \\
\text { парадна сокира за нею } \\
\text { диферент \#20 }\end{array}$ & $\begin{array}{l}302 \text { р. до. н.е. } \\
\text { [Ніколаєв 2020: } \\
\text { 39]. }\end{array}$ & $\begin{array}{c}\text { Орлик, Коцур } \\
\& \text { Циганенко } \\
2019\end{array}$ & $\begin{array}{l}9,11 \text { г. } \\
23 \text { мм. }\end{array}$ & $\begin{array}{l}\text { м.Городище, } \\
\text { Черкаський р-н, } \\
\text { Черкаська обл., } \\
2018 \text { р. }\end{array}$ \\
\hline 53 & $\begin{array}{c}\text { Ольвія, АE } \\
\text { Аv: Голова Борисфена } \\
\text { (річкового божества) } \\
\text { вліво. } \\
\text { Rv: } 3 \text { права напис ОАВІО, } \\
\text { по центру поля монети } \\
\text { горит, зліва від нього } \\
\text { парадна сокира за нею } \\
\text { диферент \#20 }\end{array}$ & $\begin{array}{l}302 \text { р. до. н.е. } \\
\text { [Ніколаєв 2020: } \\
\text { 39]. }\end{array}$ & $\begin{array}{c}\text { Орлик, Коцур } \\
\& \text { Циганенко } \\
2019\end{array}$ & $\begin{array}{c}\text { невідомо } \\
24 \text { мм. }\end{array}$ & $\begin{array}{c}\text { м.Городище, } \\
\text { Черкаський р-н, } \\
\text { Черкаська обл., } \\
2018 \text { р. }\end{array}$ \\
\hline 54 & $\begin{array}{c}\text { Ольвія, АE } \\
\text { Av: Голова Борисфена } \\
\text { (річкового божества) } \\
\text { вліво. } \\
\text { Rv: } 3 \text { права напис ОАВІО, } \\
\text { по центру поля монети } \\
\text { горит, зліва від нього } \\
\text { парадна сокира за нею } \\
\text { диферент } 20 \\
\end{array}$ & $\begin{array}{c}302 \text { р. до. н.е. } \\
\text { [Ніколаєв } \\
\text { 2020:39]. }\end{array}$ & $\begin{array}{c}\mathrm{He} \\
\text { опубліковано }\end{array}$ & $\begin{array}{c}\text { 9,30 г. } \\
\text { невідомо }\end{array}$ & $\begin{array}{c}\text { Знайдений поблизу } \\
\text { впадіння р. Бовтиш у } \\
\text { р. Тясмин, с. Івангород, } \\
\text { Олександрівська } \\
\text { селищна громада, } \\
\text { Кропивницький р-н, } \\
\text { Кіровоградська обл., } \\
2019 \text { р. }\end{array}$ \\
\hline 55 & $\begin{array}{c}\text { Ольвія, } \mathbf{A E} \\
\text { Av: Голова Борисфена } \\
\text { (річкового божества) } \\
\text { вліво. } \\
\text { Rv: } 3 \text { права напис ОАВІО, } \\
\text { по центру поля монети } \\
\text { горит, зліва від нього } \\
\text { парадна сокира за нею } \\
\text { диферент \#21 } \\
\text { (див. Рис. 1.17) }\end{array}$ & $\begin{array}{l}301 \text { р. до. н.е. } \\
\text { [Ніколаєв 2020: } \\
\text { 39]. }\end{array}$ & $\begin{array}{c}\text { Орлик, Коцур } \\
\& \text { Циганенко } \\
2019\end{array}$ & $\begin{array}{c}9,08 \\
24 \text { мм. }\end{array}$ & $\begin{array}{c}\text { м.Городище, } \\
\text { Черкаський р-н, } \\
\text { Черкаська обл., } \\
2018 \text { р. }\end{array}$ \\
\hline 56 & $\begin{array}{c}\text { Ольвія, } \mathbf{A E} \\
\text { Av: Голова Борисфена } \\
\text { (річкового божества) } \\
\text { вліво. } \\
\text { Rv: } 3 \text { права напис ОАВIO, } \\
\text { по центру поля монети } \\
\text { горит, зліва від нього } \\
\text { парадна сокира за нею } \\
\text { диферент \#21 }\end{array}$ & $\begin{array}{l}301 \text { р. до. н.е. } \\
\text { [Ніколаєв 2020: } \\
\text { 39]. }\end{array}$ & $\begin{array}{c}\text { Орлик, Коцур } \\
\& \text { Циганенко } \\
2019\end{array}$ & $\begin{array}{c}7,58 \\
22 \mathrm{mм} .\end{array}$ & $\begin{array}{l}\text { м.Городище, } \\
\text { Черкаський р-н, } \\
\text { Черкаська обл., } \\
2018 \text { р. }\end{array}$ \\
\hline
\end{tabular}


Украӥнський нумізматичний щорічник. Вип. 5. Переяслав, 2021.

\begin{tabular}{|c|c|c|c|c|c|}
\hline 1 & 2 & 3 & 4 & 5 & 6 \\
\hline 57 & $\begin{array}{c}\text { Ольвія, АE } \\
\text { Av: Голова Борисфена } \\
\text { (річкового божества) } \\
\text { вліво. } \\
\text { Rv: } 3 \text { права напис ОАВІО, } \\
\text { по центру поля монети } \\
\text { горит, зліва від нього } \\
\text { парадна сокира за нею } \\
\text { диферент \#21 }\end{array}$ & $\begin{array}{l}301 \text { р. до. н.е. } \\
\text { [Ніколаєв 2020: } \\
\text { 39]. }\end{array}$ & $\begin{array}{c}\text { Орлик, Коцур } \\
\& \text { Циганенко } \\
2019\end{array}$ & $\begin{array}{c}7,30 \\
21 \mathrm{мм} .\end{array}$ & $\begin{array}{l}\text { м.Городище, } \\
\text { Черкаський р-н, } \\
\text { Черкаська обл., } \\
2018 \text { р. }\end{array}$ \\
\hline 58 & $\begin{array}{c}\text { Ольвія, АE } \\
\text { Av: Голова Борисфена } \\
\text { (річкового божества) } \\
\text { вліво. } \\
\text { Rv: } 3 \text { права напис ОАВІО, } \\
\text { по центру поля монети } \\
\text { горит, зліва від нього } \\
\text { парадна сокира за нею } \\
\text { диферент } \# 21\end{array}$ & $\begin{array}{l}301 \text { р. до. н.е. } \\
\text { [Ніколаєв 2020: } \\
\text { 39]. }\end{array}$ & $\begin{array}{c}\text { Орлик, Коцур } \\
\text { \& Циганенко } \\
2019\end{array}$ & $\begin{array}{c}7,19 \\
22 \mathrm{мм} .\end{array}$ & $\begin{array}{l}\text { м.Городище, } \\
\text { Черкаський р-н, } \\
\text { Черкаська обл., } \\
2018 \text { р. }\end{array}$ \\
\hline 59 & $\begin{array}{c}\text { Ольвія, } \mathbf{A E} \\
\text { Av: Голова Борисфена } \\
\text { (річкового божества) } \\
\text { вліво. } \\
\text { Rv: } 3 \text { права напис ОАВІО, } \\
\text { по центру поля монети } \\
\text { горит, зліва від нього } \\
\text { парадна сокира за нею } \\
\text { диферент \#24 } \\
\end{array}$ & $\begin{array}{l}\text { 290-271 рр. до. н.е. } \\
\text { [Ніколаєв 2020: } \\
\text { 39]. }\end{array}$ & $\begin{array}{c}\text { Орлик, Коцур } \\
\text { \& Циганенко } \\
2019\end{array}$ & $\begin{array}{c}8,28 \\
22 \mathrm{мм} .\end{array}$ & $\begin{array}{l}\text { м.Городище, } \\
\text { Черкаський р-н, } \\
\text { Черкаська обл., } \\
2018 \text { р. }\end{array}$ \\
\hline 60 & $\begin{array}{c}\text { Ольвія, АE } \\
\text { Av: Голова Борисфена } \\
\text { (річкового божества) } \\
\text { вліво. } \\
\text { Rv: } 3 \text { права напис ОАВІО, } \\
\text { по центру поля монети } \\
\text { горит, зліва від нього } \\
\text { парадна сокира за нею } \\
\text { диферент \#24 }\end{array}$ & $\begin{array}{l}\text { 290-271 рр. до. н.е. } \\
\text { [Ніколаєв 2020: } \\
\text { 39]. }\end{array}$ & $\begin{array}{l}\text { Орлик, Коцур } \\
\text { \& Циганенко } \\
2019\end{array}$ & $\begin{array}{c}7,44 \\
20 \mathrm{мм} .\end{array}$ & $\begin{array}{l}\text { м.Городище, } \\
\text { Черкаський р-н, } \\
\text { Черкаська обл., } \\
2018 \text { р. }\end{array}$ \\
\hline 61 & $\begin{array}{c}\text { Ольвія, АE } \\
\text { Аv: Голова Борисфена } \\
\text { (річкового божества) } \\
\text { вліво. } \\
\text { Rv: } 3 \text { права напис ОАВІО, } \\
\text { по центру поля монети } \\
\text { горит, зліва від нього } \\
\text { парадна сокира за нею } \\
\text { диферент } 27 \\
\text { (див. Рис. } 1.18 \text { ) } \\
\end{array}$ & $\begin{array}{l}\text { 290-271 рр. до. н.е. } \\
\text { [Ніколаєв 2020: } \\
\text { 39]. }\end{array}$ & $\begin{array}{c}\text { Не } \\
\text { опубліковано }\end{array}$ & & $\begin{array}{c}\text { Знайдено на березі } \\
\text { Кременчуцького } \\
\text { водосховища, за 3-4 км. } \\
\text { вниз від с. Велика } \\
\text { Андрусівка (р-н } \\
\text { Тясминського } \\
\text { городища), } \\
\text { Олександрійський р-н, } \\
\text { Кіровоградська обл., } \\
2020 \text { p. }^{1} \\
\end{array}$ \\
\hline 62 & $\begin{array}{c}\text { Ольвія, АE } \\
\text { Av: Голова Борисфена } \\
\text { (річкового божества) } \\
\text { вліво. } \\
\text { Rv: } 3 \text { права напис ОАВІО, } \\
\text { по центру поля монети } \\
\text { горит, зліва від нього } \\
\text { парадна сокира за нею } \\
\text { диферент } 27 \\
\text { (див. Рис. } 1.18 \text { ) } \\
\end{array}$ & $\begin{array}{l}\text { 290-271 рр. до. н.е. } \\
\text { [Ніколаєв 2020: } \\
\text { 39]. }\end{array}$ & $\begin{array}{c}\mathrm{He} \\
\text { опубліковано }\end{array}$ & $\begin{array}{l}8,47 \text { г. } \\
22 \text { мм. }\end{array}$ & $\begin{array}{c}\text { с. Оситняжка } \\
\text { Кропивницький р-н, } \\
\text { Кіровоградська обл., } \\
\text { Травень } 2021\end{array}$ \\
\hline
\end{tabular}

${ }^{1}$ Автор вдячний директору Світловодського міського краєзнавчого музею Андрію Бутку за надану інформацію та світлину монети. 
The Ukrainian Numismatic Annual. Issue 5, Pereiaslav, 2021.

\begin{tabular}{|c|c|c|c|c|c|}
\hline 1 & 2 & 3 & 4 & 5 & 6 \\
\hline 63 & $\begin{array}{c}\text { Ольвія, АE } \\
\text { Av: Голова Борисфена } \\
\text { (річкового божества) } \\
\text { вліво. } \\
\text { Rv: } 3 \text { права напис ОАВIO, } \\
\text { по центру поля монети } \\
\text { горит, зліва від нього } \\
\text { парадна сокира за нею } \\
\text { диферент \#29 }\end{array}$ & $\begin{array}{l}270 \text { р. до. н.е. } \\
\text { [Ніколаєв 2020: } \\
\text { 39]. }\end{array}$ & $\begin{array}{c}\text { Орлик, Коцур } \\
\& \text { Циганенко } \\
2019\end{array}$ & $\begin{array}{c}7,07 \\
23 \text { мм. }\end{array}$ & $\begin{array}{l}\text { м.Городище, } \\
\text { Черкаський р-н, } \\
\text { Черкаська обл., } \\
2018 \text { р. }\end{array}$ \\
\hline 64 & $\begin{array}{c}\text { Ольвія, } \mathbf{A E} \\
\text { Av: Голова Борисфена } \\
\text { (річкового божества) } \\
\text { вліво. } \\
\text { Rv: } 3 \text { права напис ОАВIO, } \\
\text { по центру поля монети } \\
\text { горит, зліва від нього } \\
\text { парадна сокира за нею } \\
\text { диферент \#29 } \\
\end{array}$ & $\begin{array}{l}270 \text { р. до. н.е. } \\
\text { [Ніколаєв 2020: } \\
\text { 39]. }\end{array}$ & $\begin{array}{c}\text { Орлик, Коцур } \\
\& \text { Циганенко } \\
2019\end{array}$ & Невідомо & $\begin{array}{c}\text { м.Городище, } \\
\text { Черкаський р-н, } \\
\text { Черкаська обл., } \\
2018 \text { р. }\end{array}$ \\
\hline 65 & $\begin{array}{c}\text { Ольвія, АE } \\
\text { Av: Голова Борисфена } \\
\text { (річкового божества) } \\
\text { вліво. } \\
\text { Rv: } 3 \text { права напис ОАВІО, } \\
\text { по центру поля монети } \\
\text { горит, зліва від нього } \\
\text { парадна сокира за нею } \\
\text { диферент \#31 } \\
\text { (див. Рис. 1.20) } \\
\end{array}$ & $\begin{array}{l}268 \text { р. до. н.е. } \\
\text { [Ніколаєв 2020: } \\
\text { 39]. }\end{array}$ & $\begin{array}{c}\text { Орлик, Коцур } \\
\text { \& Циганенко } \\
2019\end{array}$ & $\begin{array}{l}\text { Невідомо } \\
22 \text { мм. }\end{array}$ & $\begin{array}{l}\text { м.Городище, } \\
\text { Черкаський р-н, } \\
\text { Черкаська обл., } \\
2018 \text { р. }\end{array}$ \\
\hline 66 & $\begin{array}{c}\text { Ольвія, } \mathbf{A E} \\
\text { Av: Голова Борисфена } \\
\text { (річкового божества) } \\
\text { вліво. } \\
\text { Rv: } 3 \text { права напис ОАВIO, } \\
\text { по центру поля монети } \\
\text { горит, зліва від нього } \\
\text { парадна сокира за нею } \\
\text { диферент \#32 } \\
\end{array}$ & $\begin{array}{l}268 \text { р. до. н.е. } \\
\text { [Ніколаєв 2020: } \\
\text { 39]. }\end{array}$ & $\begin{array}{c}\text { Орлик, Коцур } \\
\& \text { Циганенко } \\
2019\end{array}$ & $\begin{array}{l}9,00 \text { г. } \\
23 \text { мм. }\end{array}$ & $\begin{array}{l}\text { м.Городище, } \\
\text { Черкаський р-н, } \\
\text { Черкаська обл., } \\
2018 \text { р. }\end{array}$ \\
\hline 67 & $\begin{array}{c}\text { Ольвія, АE } \\
\text { Av: Голова Борисфена } \\
\text { (річкового божества) } \\
\text { вліво. } \\
\text { Rv: } 3 \text { права напис ОАВІО, } \\
\text { по центру поля монети } \\
\text { горит, зліва від нього } \\
\text { парадна сокира за нею } \\
\text { диферент } 33\end{array}$ & $\begin{array}{l}237 \text { р. до. н.е. } \\
\text { [Ніколаєв 2020: } \\
\text { 39]. }\end{array}$ & $\begin{array}{c}\mathrm{He} \\
\text { опубліковано }\end{array}$ & Невідомо & $\begin{array}{c}\text { Знайдений поблизу } \\
\text { впадіння р. Бовтиш у } \\
\text { р. Тясмин, с. Івангород, } \\
\text { Олександрівська } \\
\text { селищна громада, } \\
\text { Кропивницький р-н, } \\
\text { Кіровоградська обл., } \\
2019 \text { р. }\end{array}$ \\
\hline 68 & $\begin{array}{c}\text { Ольвія, АE } \\
\text { Av: Голова Борисфена } \\
\text { (річкового божества) } \\
\text { вліво. } \\
\text { Rv: } 3 \text { права напис ОАВIO, } \\
\text { по центру поля монети } \\
\text { горит, зліва від нього } \\
\text { парадна сокира за нею } \\
\text { диферент \#35 }\end{array}$ & $\begin{array}{l}266 \text { р. до. н.е. } \\
\text { [Ніколаєв 2020: } \\
\text { 39]. }\end{array}$ & $\begin{array}{c}\text { Орлик, Коцур } \\
\& \text { Циганенко } \\
2019\end{array}$ & Невідомо & $\begin{array}{c}\text { м.Городище, } \\
\text { Черкаський р-н, } \\
\text { Черкаська обл., } \\
2018 \text { р. }\end{array}$ \\
\hline 69 & $\begin{array}{c}\text { Ольвія, } \mathbf{A E} \\
\text { Av: Голова Борисфена } \\
\text { (річкового божества) } \\
\text { вліво. } \\
\text { Rv: } 3 \text { права напис ОАВІО, } \\
\text { по центру поля монети } \\
\text { горит, зліва від нього } \\
\text { парадна сокира за нею } \\
\text { диферент \#36 }\end{array}$ & $\begin{array}{l}265 \text { р. до. н.е. } \\
\text { [Ніколаєв 2020: } \\
\text { 39]. }\end{array}$ & Ляшко 2017-а & $\begin{array}{l}9,36 \text { г. } \\
22 \text { мм. }\end{array}$ & $\begin{array}{c}\text { с. Райгород, } \\
\text { Михайлівська сільська } \\
\text { ОТГ, Черкаський р-н, } \\
\text { Черкаська обл., } \\
2017 \text { р. }\end{array}$ \\
\hline
\end{tabular}


Украӥнський нумізматичний щорічник. Вип. 5. Переяслав, 2021.

\begin{tabular}{|c|c|c|c|c|c|}
\hline 1 & 2 & 3 & 4 & 5 & 6 \\
\hline 70 & $\begin{array}{c}\text { Ольвія, } \mathbf{A E} \\
\text { Av: Голова Борисфена } \\
\text { (річкового божества) } \\
\text { вліво. } \\
\text { Rv: } 3 \text { права напис ОАВIO, } \\
\text { по центру поля монети } \\
\text { горит, зліва від нього } \\
\text { парадна сокира за нею } \\
\text { диферент \#36 }\end{array}$ & $\begin{array}{l}265 \text { р. до. н.е. } \\
\text { [Ніколаєв 2020: } \\
\text { 39]. }\end{array}$ & $\begin{array}{c}\text { Не } \\
\text { опубліковано }\end{array}$ & $\begin{array}{c}9,80 \text { г. } \\
\text { Невідомо }\end{array}$ & $\begin{array}{c}\text { Знайдений поблизу } \\
\text { впадіння р. Бовтиш у } \\
\text { р. Тясмин, с. Івангород, } \\
\text { Олександрівська } \\
\text { селищна громада, } \\
\text { Кропивницький р-н, } \\
\text { Кіровоградська обл., } \\
2019 \text { р. }\end{array}$ \\
\hline 71 & $\begin{array}{c}\text { Ольвія, } \mathbf{A E} \\
\text { Av: Голова Борисфена } \\
\text { (річкового божества) } \\
\text { вліво. } \\
\text { Rv: } 3 \text { права напис ОАВIO, } \\
\text { по центру поля монети } \\
\text { горит, зліва від нього } \\
\text { парадна сокира за нею } \\
\text { диферент \#36 }\end{array}$ & $\begin{array}{l}265 \text { р. до. н.е. } \\
\text { [Ніколаєв 2020: } \\
\text { 39]. }\end{array}$ & $\begin{array}{c}\text { Не } \\
\text { опубліковано }\end{array}$ & $\begin{array}{l}9,16 \text { г. } \\
21 \text { мм. }\end{array}$ & $\begin{array}{c}\text { Знайдений поблизу } \\
\text { впадіння р. Бовтиш у } \\
\text { р. Тясмин, с. Івангород, } \\
\text { Олександрівська } \\
\text { селищна громада, } \\
\text { Кропивницький р-н, } \\
\text { Кіровоградська обл., } \\
2019 \text { р. }\end{array}$ \\
\hline 72 & $\begin{array}{c}\text { Ольвія, } \mathbf{A E} \\
\text { Av: Голова Борисфена } \\
\text { (річкового божества) } \\
\text { вліво. } \\
\text { Rv: з права напис ОАВIO, } \\
\text { по центру поля монети } \\
\text { горит, зліва від нього } \\
\text { парадна сокира за нею } \\
\text { диферент \#40 } \\
\end{array}$ & $\begin{array}{l}262 \text { р. до. н.е. } \\
\text { [Ніколаєв 2020: } \\
\text { 39]. }\end{array}$ & $\begin{array}{c}\text { Орлик, Коцур } \\
\text { \& Циганенко } \\
2019\end{array}$ & $\begin{array}{l}10,18 \text { г. } \\
23 \text { мм. }\end{array}$ & $\begin{array}{l}\text { м.Городище, } \\
\text { Черкаський р-н, } \\
\text { Черкаська обл., } \\
2018 \text { р. }\end{array}$ \\
\hline 73 & $\begin{array}{c}\text { Ольвія, } \mathbf{A E} \\
\text { Av: Голова Борисфена } \\
\text { (річкового божества) } \\
\text { вліво. } \\
\text { Rv: } 3 \text { права напис ОАВIO, } \\
\text { по центру поля монети } \\
\text { горит, зліва від нього } \\
\text { парадна сокира за нею } \\
\text { диферент \#40 }\end{array}$ & $\begin{array}{l}262 \text { р. до. н.е. } \\
\text { [Ніколаєв 2020: } \\
\text { 39]. }\end{array}$ & forum.violity & $\begin{array}{l}8,54 \text { г. } \\
21 \text { мм. }\end{array}$ & $\begin{array}{l}\text { с. Червона Слобода, } \\
\text { Черкаський р-н, } \\
\text { Черкаська обл., } \\
2021 \text { р. }\end{array}$ \\
\hline 74 & $\begin{array}{c}\text { Ольвія, } \mathbf{A E} \\
\text { Av: Голова Борисфена } \\
\text { (річкового божества) } \\
\text { вліво. } \\
\text { Rv: } 3 \text { права напис ОАВIO, } \\
\text { по центру поля монети } \\
\text { горит, зліва від нього } \\
\text { парадна сокира за нею } \\
\text { диферент \#42 }\end{array}$ & $\begin{array}{l}261 \text { р. до. н.е. } \\
\text { [Ніколаєв 2020: } \\
\text { 39]. }\end{array}$ & $\begin{array}{c}\text { Орлик, Коцур } \\
\text { \& Циганенко } \\
2019\end{array}$ & $\begin{array}{l}9,12 \text { г. } \\
22 \text { мм. }\end{array}$ & $\begin{array}{l}\text { м.Городище, } \\
\text { Черкаський р-н, } \\
\text { Черкаська обл., } \\
2018 \text { р. }\end{array}$ \\
\hline 75 & $\begin{array}{c}\text { Ольвія, } \mathbf{A E} \\
\text { Av: Голова Борисфена } \\
\text { (річкового божества) } \\
\text { вліво. } \\
\text { Rv: } 3 \text { права напис ОАВIO, } \\
\text { по центру поля монети } \\
\text { горит, зліва від нього } \\
\text { парадна сокира за нею } \\
\text { диферент \#42 }\end{array}$ & $\begin{array}{l}261 \text { р. до. н.е. } \\
\text { [Ніколаєв 2020: } \\
\text { 39]. }\end{array}$ & $\begin{array}{c}\text { Орлик, Коцур } \\
\text { \& Циганенко } \\
2019\end{array}$ & $\begin{array}{l}7,58 \text { г. } \\
22 \text { мм. }\end{array}$ & $\begin{array}{l}\text { м.Городище, } \\
\text { Черкаський р-н, } \\
\text { Черкаська обл., } \\
2018 \text { р. }\end{array}$ \\
\hline 76 & $\begin{array}{c}\text { Ольвія, } \mathbf{A E} \\
\text { Av: Голова Борисфена } \\
\text { (річкового божества) } \\
\text { вліво. } \\
\text { Rv: } 3 \text { права напис ОАВIO, } \\
\text { по центру поля монети } \\
\text { горит, зліва від нього } \\
\text { парадна сокира за нею } \\
\text { диферент \#42 }\end{array}$ & $\begin{array}{l}261 \text { р. до. н.е. } \\
\text { [Ніколаєв 2020: } \\
\text { 39]. }\end{array}$ & $\begin{array}{c}\text { Орлик, Коцур } \\
\text { \& Циганенко } \\
2019\end{array}$ & Невідомо & $\begin{array}{l}\text { м.Городище, } \\
\text { Черкаський р-н, } \\
\text { Черкаська обл., } \\
2018 \text { р. }\end{array}$ \\
\hline
\end{tabular}


The Ukrainian Numismatic Annual. Issue 5, Pereiaslav, 2021.

\begin{tabular}{|c|c|c|c|c|c|}
\hline 1 & 2 & 3 & 4 & 5 & 6 \\
\hline 77 & $\begin{array}{c}\text { Ольвія, АE } \\
\text { Аv: Голова Борисфена } \\
\text { (річкового божества) } \\
\text { вліво. } \\
\text { Rv: } 3 \text { права напис ОАВIO, } \\
\text { по центру поля монети } \\
\text { горит, зліва від нього } \\
\text { парадна сокира за нею } \\
\text { диферент \#42 }\end{array}$ & $\begin{array}{l}261 \text { р. до. н.е. } \\
\text { [Ніколаєв 2020: } \\
\text { 39]. }\end{array}$ & $\begin{array}{c}\text { Орлик, Коцур } \\
\text { \& Циганенко } \\
2019\end{array}$ & Невідомо & $\begin{array}{l}\text { м.Городище, } \\
\text { Черкаський р-н, } \\
\text { Черкаська обл., } \\
2018 \text { р. }\end{array}$ \\
\hline 78 & $\begin{array}{c}\text { Ольвія, } \mathbf{A E} \\
\text { Av: Голова Борисфена } \\
\text { (річкового божества) } \\
\text { вліво. } \\
\text { Rv: } 3 \text { права напис ОАВІО, } \\
\text { по центру поля монети } \\
\text { горит, зліва від нього } \\
\text { парадна сокира за нею } \\
\text { диферент } 46 \\
\text { (див. Рис. } 1.21 \text { ) } \\
\end{array}$ & $\begin{array}{l}257 \text { р. до. н.е. } \\
\text { [Ніколаєв 2020: } \\
\text { 39]. }\end{array}$ & $\begin{array}{c}\mathrm{He} \\
\text { опубліковано }\end{array}$ & Невідомо & $\begin{array}{c}\text { с. Підлісне, } \\
\text { Олександрівська } \\
\text { селищна громада, } \\
\text { Кропивницький р-н, } \\
\text { Кіровоградська обл., } \\
2020 \text { р. }\end{array}$ \\
\hline 79 & $\begin{array}{c}\text { Ольвія, } \mathbf{A E} \\
\text { Av: Голова Борисфена } \\
\text { (річкового божества) } \\
\text { вліво. } \\
\text { Rv: } 3 \text { права напис ОАВIО, } \\
\text { по центру поля монети } \\
\text { горит, зліва від нього } \\
\text { парадна сокира за нею } \\
\text { диферент \#50 } \\
\end{array}$ & $\begin{array}{l}254 \text { р. до. н.е. } \\
\text { [Ніколаєв 2020: } \\
\text { 39]. }\end{array}$ & $\begin{array}{c}\text { Орлик, Коцур } \\
\& \text { Циганенко } \\
2019\end{array}$ & $\begin{array}{l}8,22 \text { г. } \\
22 \text { мм. }\end{array}$ & $\begin{array}{l}\text { м.Городище, } \\
\text { Черкаський р-н, } \\
\text { Черкаська обл., } \\
2018 \text { р. }\end{array}$ \\
\hline 80 & $\begin{array}{c}\text { Ольвія, } \mathbf{A E} \\
\text { Av: Голова Борисфена } \\
\text { (річкового божества) } \\
\text { вліво. } \\
\text { Rv: } 3 \text { права напис ОАВIО, } \\
\text { по центру поля монети } \\
\text { горит, зліва від нього } \\
\text { парадна сокира за нею } \\
\text { диферент \#51 } \\
\end{array}$ & $\begin{array}{l}253 \text { р. до. н.е. } \\
\text { [Ніколаєв 2020: } \\
\text { 39]. }\end{array}$ & $\begin{array}{c}\text { Орлик, Коцур } \\
\& \text { Циганенко } \\
2019\end{array}$ & $\begin{array}{l}\text { невідомо } \\
21 \text { мм. }\end{array}$ & $\begin{array}{l}\text { м.Городище, } \\
\text { Черкаський р-н, } \\
\text { Черкаська обл., } \\
2018 \text { р. }\end{array}$ \\
\hline 81 & $\begin{array}{c}\text { Ольвія, АE } \\
\text { Аv: Голова Борисфена } \\
\text { (річкового божества) } \\
\text { вліво. } \\
\text { Rv: } 3 \text { права напис ОАВIО, } \\
\text { по центру поля монети } \\
\text { горит, зліва від нього } \\
\text { парадна сокира за нею } \\
\text { диферент \#53 } \\
\end{array}$ & $\begin{array}{l}251 \text { р. до. н.е. } \\
\text { [Ніколаєв 2020: } \\
\text { 39]. }\end{array}$ & $\begin{array}{c}\text { Орлик, Коцур } \\
\text { \& Циганенко } \\
2019\end{array}$ & $\begin{array}{c}8,41 \\
22 \mathrm{мм} .\end{array}$ & $\begin{array}{c}\text { м.Городище, } \\
\text { Черкаський р-н, } \\
\text { Черкаська обл., } \\
2018 \text { р. }\end{array}$ \\
\hline 82 & $\begin{array}{c}\text { Ольвія, АE } \\
\text { Av: Голова Борисфена } \\
\text { (річкового божества) } \\
\text { вліво. } \\
\text { Rv: } 3 \text { права напис ОАВIO, } \\
\text { по центру поля монети } \\
\text { горит, зліва від нього } \\
\text { парадна сокира за нею } \\
\text { диферент \#59 }\end{array}$ & $\begin{array}{l}246 \text { р. до. н.е. } \\
\text { [Ніколаєв 2020: } \\
\text { 39]. }\end{array}$ & $\begin{array}{c}\mathrm{He} \\
\text { опубліковано }\end{array}$ & $\begin{array}{l}10,03 \text { г. } \\
21 \text { мм. }\end{array}$ & $\begin{array}{c}\text { Знайдений поблизу } \\
\text { впадіння р. Бовтиш у } \\
\text { р. Тясмин, с. Івангород, } \\
\text { Олександрівська } \\
\text { селищна громада, } \\
\text { Кропивницький р-н, } \\
\text { Кіровоградська обл., } \\
2019 \text { р. }\end{array}$ \\
\hline 83 & $\begin{array}{c}\text { Ольвія, АE } \\
\text { Av: Голова Борисфена } \\
\text { (річкового божества) } \\
\text { вліво. } \\
\text { Rv: } 3 \text { права напис ОАВІО, } \\
\text { по центру поля монети } \\
\text { горит, зліва від нього } \\
\text { парадна сокира за нею } \\
\text { диферент \#59 } \\
\text { (див. Рис. 1.22) } \\
\end{array}$ & $\begin{array}{l}246 \text { р. до. н.е. } \\
\text { [Ніколаєв 2020: } \\
\text { 39]. }\end{array}$ & $\begin{array}{c}\mathrm{He} \\
\text { опубліковано }\end{array}$ & Невідомо & $\begin{array}{c}\text { Знайдений поблизу } \\
\text { впадіння р. Бовтиш у } \\
\text { р. Тясмин, с. Івангород, } \\
\text { Олександрівська } \\
\text { селищна громада, } \\
\text { Кропивницький р-н, } \\
\text { Кіровоградська обл., } \\
2019 \text { р. }\end{array}$ \\
\hline
\end{tabular}


Украӥнський нумізматичний щорічник. Вип. 5. Переяслав, 2021.

\begin{tabular}{|c|c|c|c|c|c|}
\hline 1 & 2 & 3 & 4 & 5 & 6 \\
\hline 84 & $\begin{array}{c}\text { Ольвія, АE } \\
\text { Av: Голова Борисфена } \\
\text { (річкового божества) } \\
\text { вліво. } \\
\text { Rv: } 3 \text { права напис ОАВIO, } \\
\text { по центру поля монети } \\
\text { горит, зліва від нього } \\
\text { парадна сокира за нею } \\
\text { диферент \#61 }\end{array}$ & $\begin{array}{l}244 \text { р. до. н.е. } \\
\text { [Ніколаєв 2020: } \\
\text { 39]. }\end{array}$ & $\begin{array}{c}\text { Орлик, Коцур } \\
\text { \& Циганенко } \\
2019\end{array}$ & $\begin{array}{l}\text { Невідомо } \\
20 \text { мм. }\end{array}$ & $\begin{array}{l}\text { м.Городище, } \\
\text { Черкаський р-н, } \\
\text { Черкаська обл., } \\
2018 \text { р. }\end{array}$ \\
\hline 85 & $\begin{array}{c}\text { Ольвія, } \mathbf{A E} \\
\text { Av: Голова Борисфена } \\
\text { (річкового божества) } \\
\text { вліво. } \\
\text { Rv: } 3 \text { права напис ОАВІО, } \\
\text { по центру поля монети } \\
\text { горит, зліва від нього } \\
\text { парадна сокира за нею } \\
\text { диферент \#66 } \\
\end{array}$ & $\begin{array}{l}241 \text { р. до. н.е. } \\
\text { [Ніколаєв 2020: } \\
\text { 39]. }\end{array}$ & $\begin{array}{c}\text { Орлик, Коцур } \\
\text { \& Циганенко } \\
2019\end{array}$ & $\begin{array}{c}6,97 \\
19 \text { мм. }\end{array}$ & $\begin{array}{l}\text { м.Городище, } \\
\text { Черкаський р-н, } \\
\text { Черкаська обл., } \\
2018 \text { р. }\end{array}$ \\
\hline 86 & $\begin{array}{c}\text { Ольвія, } \mathbf{A E} \\
\text { Av: Голова Борисфена } \\
\text { (річкового божества) } \\
\text { вліво. } \\
\text { Rv: з права напис ОАВIO, } \\
\text { по центру поля монети } \\
\text { горит, зліва від нього } \\
\text { парадна сокира за нею } \\
\text { диферент \#66 }\end{array}$ & $\begin{array}{l}241 \text { р. до. н.е. } \\
\text { [Ніколаєв 2020: } \\
\text { 39]. }\end{array}$ & $\begin{array}{c}\text { Орлик, Коцур } \\
\text { \& Циганенко } \\
2019\end{array}$ & $\begin{array}{c}6,49 \\
20 \text { мм. }\end{array}$ & $\begin{array}{l}\text { м.Городище, } \\
\text { Черкаський р-н, } \\
\text { Черкаська обл., } \\
2018 \text { р. }\end{array}$ \\
\hline 87 & $\begin{array}{c}\text { Ольвія, АE } \\
\text { Av: Голова Борисфена } \\
\text { (річкового божества) } \\
\text { вліво. } \\
\text { Rv: } 3 \text { права напис ОАВIО, } \\
\text { по центру поля монети } \\
\text { горит, зліва від нього } \\
\text { парадна сокира за нею } \\
\text { диферент \#67 }\end{array}$ & $\begin{array}{l}240 \text { р. до. н.е. } \\
\text { [Ніколаєв 2020: } \\
\text { 39]. }\end{array}$ & $\begin{array}{c}\text { Орлик, Коцур } \\
\text { \& Циганенко } \\
2019\end{array}$ & $\begin{array}{l}\text { Невідомо } \\
22 \text { мм. }\end{array}$ & $\begin{array}{l}\text { м.Городище, } \\
\text { Черкаський р-н, } \\
\text { Черкаська обл., } \\
2018 \text { р. }\end{array}$ \\
\hline 88 & $\begin{array}{c}\text { Ольвія, } \mathbf{A E} \\
\text { Av: Голова Борисфена } \\
\text { (річкового божества) } \\
\text { вліво. } \\
\text { Rv: } 3 \text { права напис ОАВІО, } \\
\text { по центру поля монети } \\
\text { горит, зліва від нього } \\
\text { парадна сокира за нею } \\
\text { диферент \#67 } \\
\text { (див. Рис. } 1.23 \text { ) } \\
\end{array}$ & $\begin{array}{l}240 \text { р. до. н.е. }+14 \\
\text { p [Ніколаєв 2020: } \\
\text { 39]. }\end{array}$ & $\begin{array}{c}\text { Не } \\
\text { опубліковано }\end{array}$ & $\begin{array}{l}10,5 \text { г., } \\
22 \mathrm{мм}\end{array}$ & $\begin{array}{c}\text { Знайдено поблизу } \\
\text { с. Гутниця, } \\
\text { Олександрівська } \\
\text { селищна громада, } \\
\text { Кропивницький р-н, } \\
\text { Кіровоградська обл. }\end{array}$ \\
\hline 89 & $\begin{array}{c}\text { Ольвія, АE } \\
\text { Av: Голова Борисфена } \\
\text { (річкового божества) } \\
\text { вліво. } \\
\text { Rv: } 3 \text { права напис ОАВІО, } \\
\text { по центру поля монети } \\
\text { горит, зліва від нього } \\
\text { парадна сокира за нею } \\
\text { диферент \#69 }\end{array}$ & $\begin{array}{l}238 \text { р. до. н.е. } \\
\text { [Ніколаєв 2020: } \\
\text { 39]. }\end{array}$ & $\begin{array}{c}\text { Орлик, Коцур } \\
\text { \& Циганенко } \\
2019\end{array}$ & $\begin{array}{l}\text { Невідомо } \\
20 \text { мм. }\end{array}$ & $\begin{array}{l}\text { м.Городище, } \\
\text { Черкаський р-н, } \\
\text { Черкаська обл., } \\
2018 \text { р. }\end{array}$ \\
\hline 90 & $\begin{array}{c}\text { Ольвія, } \mathbf{A E} \\
\text { Av: Голова Борисфена } \\
\text { (річкового божества) } \\
\text { вліво. } \\
\text { Rv: } 3 \text { права напис ОАВIО, } \\
\text { по центру поля монети } \\
\text { горит, зліва від нього } \\
\text { парадна сокира за нею } \\
\text { диферент \#69 }\end{array}$ & $\begin{array}{l}238 \text { р. до. н.е. } \\
\text { [Ніколаєв 2020: } \\
\text { 39]. }\end{array}$ & $\begin{array}{c}\text { Орлик, Коцур } \\
\text { \& Циганенко } \\
2019\end{array}$ & $\begin{array}{c}6,60 \\
22 \text { мм. }\end{array}$ & $\begin{array}{l}\text { м.Городище, } \\
\text { Черкаський р-н, } \\
\text { Черкаська обл., } \\
2018 \text { р. }\end{array}$ \\
\hline
\end{tabular}


The Ukrainian Numismatic Annual. Issue 5, Pereiaslav, 2021.

\begin{tabular}{|c|c|c|c|c|c|}
\hline 1 & 2 & 3 & 4 & 5 & 6 \\
\hline 91 & $\begin{array}{c}\text { Ольвія, АE } \\
\text { Av: Голова Борисфена } \\
\text { (річкового божества) } \\
\text { вліво. } \\
\text { Rv: } ~ з \text { права напис ОАВІО, } \\
\text { по центру поля монети } \\
\text { горит, зліва від нього } \\
\text { парадна сокира за нею } \\
\text { диферент \#70 }\end{array}$ & $\begin{array}{l}237 \text { р. до. н.е. } \\
\text { [Ніколаєв 2020: } \\
\text { 39]. }\end{array}$ & $\begin{array}{c}\text { Орлик, Коцур } \\
\& \text { Циганенко } \\
2019\end{array}$ & $\begin{array}{c}6,00 \\
22 \mathrm{мм} .\end{array}$ & $\begin{array}{l}\text { м.Городище, } \\
\text { Черкаський р-н, } \\
\text { Черкаська обл., } \\
2018 \text { р. }\end{array}$ \\
\hline 92 & $\begin{array}{c}\text { Ольвія, } \mathbf{A E} \\
\text { Av: Голова Борисфена } \\
\text { (річкового божества) } \\
\text { вліво. } \\
\text { Rv: } 3 \text { права напис ОАВIO, } \\
\text { по центру поля монети } \\
\text { горит, зліва від нього } \\
\text { парадна сокира за нею } \\
\text { диферент \#70 }\end{array}$ & $\begin{array}{l}237 \text { р. до. н.е. } \\
\text { [Ніколаєв 2020: } \\
\text { 39]. }\end{array}$ & $\begin{array}{c}\text { Орлик, Коцур } \\
\text { \& Циганенко } \\
2019\end{array}$ & $\begin{array}{c}\text { Невідомо } \\
21 \text { мм. }\end{array}$ & $\begin{array}{l}\text { м.Городище, } \\
\text { Черкаський р-н, } \\
\text { Черкаська обл., } \\
2018 \text { р. }\end{array}$ \\
\hline 93 & $\begin{array}{c}\text { Ольвія, АE } \\
\text { Av: Голова Борисфена } \\
\text { (річкового божества) } \\
\text { вліво. } \\
\text { Rv: } 3 \text { права напис ОАВІО, } \\
\text { по центру поля монети } \\
\text { горит, зліва від нього } \\
\text { парадна сокира за нею } \\
\text { диферент \#70 }\end{array}$ & $\begin{array}{l}237 \text { р. до. н.е. } \\
\text { [Ніколаєв 2020: } \\
\text { 39]. }\end{array}$ & $\begin{array}{c}\text { Не } \\
\text { опубліковано }\end{array}$ & $\begin{array}{l}9,46 \text { г. } \\
22 \text { мм }\end{array}$ & $\begin{array}{c}\text { Знайдений поблизу } \\
\text { впадіння р. Бовтиш у } \\
\text { р. Тясмин, с. Івангород, } \\
\text { Олександрівська } \\
\text { селищна громада, } \\
\text { Кропивницький р-н, } \\
\text { Кіровоградська обл., } \\
2019 \text { р. }\end{array}$ \\
\hline 94 & $\begin{array}{c}\text { Ольвія, АE } \\
\text { Av: Голова Борисфена } \\
\text { (річкового божества) } \\
\text { вліво. } \\
\text { Rv: } 3 \text { права напис ОАВІО, } \\
\text { по центру поля монети } \\
\text { горит, зліва від нього } \\
\text { парадна сокира за нею } \\
\text { диферент \#70 } \\
\text { Монета має отвір. } \\
\end{array}$ & $\begin{array}{l}237 \text { р. до. н.е. } \\
\text { [Ніколаєв 2020: } \\
\text { 39]. }\end{array}$ & $\begin{array}{c}\mathrm{He} \\
\text { опубліковано }\end{array}$ & $\begin{array}{l}9,04 \text { г. } \\
22 \text { мм. }\end{array}$ & $\begin{array}{c}\text { с. Оситняжка } \\
\text { Кропивницький р-н, } \\
\text { Кіровоградська обл., } \\
\text { травень } 2021\end{array}$ \\
\hline 95 & $\begin{array}{c}\text { Ольвія, АE } \\
\text { Av: Голова Борисфена } \\
\text { (річкового божества) } \\
\text { вліво. } \\
\text { Rv: } 3 \text { права напис ОАВІО, } \\
\text { по центру поля монети } \\
\text { горит, зліва від нього } \\
\text { парадна сокира за нею } \\
\text { диферент \#74 }\end{array}$ & $\begin{array}{l}236 \text { р. до. н.е. } \\
\text { [Ніколаєв 2020: } \\
\text { 39]. }\end{array}$ & $\begin{array}{c}\text { Орлик, Коцур } \\
\& \text { Циганенко } \\
2019\end{array}$ & $\begin{array}{c}8,28 \\
22 \text { мм. }\end{array}$ & $\begin{array}{l}\text { м.Городище, } \\
\text { Черкаський р-н, } \\
\text { Черкаська обл., } \\
2018 \text { р. }\end{array}$ \\
\hline 96 & $\begin{array}{c}\text { Ольвія, АE } \\
\text { Av: Голова Борисфена } \\
\text { (річкового божества) } \\
\text { вліво. } \\
\text { Rv: } 3 \text { права напис ОАВІО, } \\
\text { по центру поля монети } \\
\text { горит, зліва від нього } \\
\text { парадна сокира за нею } \\
\text { диферент \#74 }\end{array}$ & $\begin{array}{l}236 \text { р. до. н.е. } \\
\text { [Ніколаєв 2020: } \\
\text { 39]. }\end{array}$ & $\begin{array}{c}\text { Орлик, Коцур } \\
\& \text { Циганенко } \\
2019\end{array}$ & $\begin{array}{c}\text { Невідомо } \\
23 \text { мм. }\end{array}$ & $\begin{array}{l}\text { м.Городище, } \\
\text { Черкаський р-н, } \\
\text { Черкаська обл., } \\
2018 \text { р. }\end{array}$ \\
\hline 97 & $\begin{array}{c}\text { Ольвія, АE } \\
\text { Аv: Голова Борисфена } \\
\text { (річкового божества) } \\
\text { вліво. } \\
\text { Rv: } 3 \text { права напис ОАВІО, } \\
\text { по центру поля монети } \\
\text { горит, зліва від нього } \\
\text { парадна сокира за нею } \\
\text { диферент \#76 }\end{array}$ & $\begin{array}{l}235 \text { р. до. н.е. } \\
\text { [Ніколаєв 2020: } \\
\text { 39]. }\end{array}$ & $\begin{array}{c}\mathrm{He} \\
\text { опубліковано }\end{array}$ & $\begin{array}{l}8,96 \text { г. } \\
22 \text { мм. }\end{array}$ & $\begin{array}{c}\text { Між селами } \\
\text { Капітанівка, } \\
\text { Новомиргородська } \\
\text { міська громада, } \\
\text { Новоукраїнський р-н, } \\
\text { Кіровоградська обл. та } \\
\text { Пастирське, Тернівська } \\
\text { сільська ОТГ, } \\
\text { Черкаський р-н, } \\
\text { Черкаська обл., на межі } \\
\text { областей, } 2021 \text { р. }\end{array}$ \\
\hline
\end{tabular}


Украӥнський нумізматичний щорічник. Вип. 5. Переяслав, 2021.

\begin{tabular}{|c|c|c|c|c|c|}
\hline 1 & 2 & 3 & 4 & 5 & 6 \\
\hline 98 & $\begin{array}{c}\text { Ольвія, АE } \\
\text { Av: Голова Борисфена } \\
\text { (річкового божества) } \\
\text { вліво. } \\
\text { Rv: } 3 \text { права напис ОАВІО, } \\
\text { по центру поля монети } \\
\text { горит, зліва від нього } \\
\text { парадна сокира за нею } \\
\text { диферент \#79 }\end{array}$ & $\begin{array}{l}232 \text { р. до. н.е. } \\
\text { [Ніколаєв 2020: } \\
\text { 39]. }\end{array}$ & $\begin{array}{c}\text { Орлик, Коцур } \\
\text { \& Циганенко } \\
2019\end{array}$ & $\begin{array}{c}6,89 \\
20 \text { мм. }\end{array}$ & $\begin{array}{c}\text { м.Городище, } \\
\text { Черкаський р-н, } \\
\text { Черкаська обл., } \\
2018 \text { р. }\end{array}$ \\
\hline 99 & $\begin{array}{c}\text { Ольвія, АE } \\
\text { Av: Голова Борисфена } \\
\text { (річкового божества) } \\
\text { вліво. } \\
\text { Rv: } 3 \text { права напис ОАВІО, } \\
\text { по центру поля монети } \\
\text { горит, зліва від нього } \\
\text { парадна сокира за нею } \\
\text { диферент \#82 }\end{array}$ & $\begin{array}{l}228 \text { р. до. н.е. } \\
\text { [Ніколаєв 2020: } \\
\text { 39]. }\end{array}$ & $\begin{array}{c}\text { Орлик, Коцур } \\
\text { \& Циганенко } \\
2019\end{array}$ & $\begin{array}{c}5,39 \\
21 \mathrm{мм} .\end{array}$ & $\begin{array}{l}\text { м.Городище, } \\
\text { Черкаський р-н, } \\
\text { Черкаська обл., } \\
2018 \text { р. }\end{array}$ \\
\hline 100 & $\begin{array}{c}\text { Ольвія, } \mathbf{A E} \\
\text { Av: Голова Борисфена } \\
\text { (річкового божества) } \\
\text { вліво. } \\
\text { Rv: } 3 \text { права напис ОАВІО, } \\
\text { по центру поля монети } \\
\text { горит, зліва від нього } \\
\text { парадна сокира за нею } \\
\text { диферент \#82 } \\
\end{array}$ & $\begin{array}{l}228 \text { р. до. н.е. } \\
\text { [Ніколаєв 2020: } \\
\text { 39]. }\end{array}$ & $\begin{array}{c}\text { Орлик, Коцур } \\
\text { \& Циганенко } \\
2019\end{array}$ & $\begin{array}{c}\text { Невідомо } \\
19 \text { мм. }\end{array}$ & $\begin{array}{c}\text { м.Городище, } \\
\text { Черкаський р-н, } \\
\text { Черкаська обл., } \\
2018 \text { р. }\end{array}$ \\
\hline 101 & $\begin{array}{c}\text { Ольвія, } \mathbf{A E} \\
\text { Av: Голова Борисфена } \\
\text { (річкового божества) } \\
\text { вліво. } \\
\text { Rv: } 3 \text { права напис ОАВІО, } \\
\text { по центру поля монети } \\
\text { горит, зліва від нього } \\
\text { парадна сокира за нею } \\
\text { диферент \#84 } \\
\end{array}$ & $\begin{array}{l}227 \text { р. до. н.е. } \\
\text { [Ніколаєв 2020: } \\
\text { 39]. }\end{array}$ & $\begin{array}{c}\text { Орлик, Коцур } \\
\text { \& Циганенко } \\
2019\end{array}$ & $\begin{array}{c}5,84 \\
19 \text { мм. }\end{array}$ & $\begin{array}{c}\text { м.Городище, } \\
\text { Черкаський р-н, } \\
\text { Черкаська обл., } \\
2018 \text { р. }\end{array}$ \\
\hline 102 & $\begin{array}{c}\text { Ольвія, АE } \\
\text { Av: Голова Борисфена } \\
\text { (річкового божества) } \\
\text { вліво. } \\
\text { Rv: } 3 \text { права напис ОАВІО, } \\
\text { по центру поля монети } \\
\text { горит, зліва від нього } \\
\text { парадна сокира за нею } \\
\text { диферент \#84 }\end{array}$ & $\begin{array}{l}227 \text { р. до. н.е. } \\
\text { [Ніколаєв 2020: } \\
\text { 39]. }\end{array}$ & $\begin{array}{c}\text { Орлик, Коцур } \\
\text { \& Циганенко } \\
2019\end{array}$ & $\begin{array}{c}6,62 \\
18 \mathrm{mM} .\end{array}$ & $\begin{array}{c}\text { м.Городище, } \\
\text { Черкаський р-н, } \\
\text { Черкаська обл., } \\
2018 \text { р. }\end{array}$ \\
\hline 103 & $\begin{array}{c}\text { Ольвія, } \mathbf{A E} \\
\text { Av: Голова Борисфена } \\
\text { (річкового божества) } \\
\text { вліво. } \\
\text { Rv: } 3 \text { права напис ОАВІО, } \\
\text { по центру поля монети } \\
\text { горит, зліва від нього } \\
\text { парадна сокира за нею } \\
\text { диферент \#85 }\end{array}$ & $\begin{array}{l}227 \text { р. до. н.е. } \\
\text { [Ніколаєв 2020: } \\
\text { 39]. }\end{array}$ & $\begin{array}{c}\text { Орлик, Коцур } \\
\text { \& Циганенко } \\
2019\end{array}$ & $\begin{array}{c}\text { Невідомо } \\
19 \text { мм. }\end{array}$ & $\begin{array}{c}\text { м.Городище, } \\
\text { Черкаський р-н, } \\
\text { Черкаська обл., } \\
2018 \text { р. }\end{array}$ \\
\hline 104 & 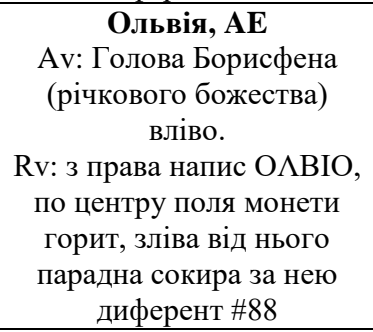 & $\begin{array}{l}225 \text { р. до. н.е. } \\
\text { [Ніколаєв 2020: } \\
\text { 39]. }\end{array}$ & $\begin{array}{c}\text { Орлик, Коцур } \\
\text { \& Циганенко } \\
2019\end{array}$ & $\begin{array}{c}6,92 \\
19 \text { мм. }\end{array}$ & $\begin{array}{c}\text { м.Городище, } \\
\text { Черкаський р-н, } \\
\text { Черкаська обл., } \\
2018 \text { р. }\end{array}$ \\
\hline
\end{tabular}


The Ukrainian Numismatic Annual. Issue 5, Pereiaslav, 2021.

\begin{tabular}{|c|c|c|c|c|c|}
\hline 1 & 2 & 3 & 4 & 5 & 6 \\
\hline 105 & $\begin{array}{c}\text { Ольвія, АE } \\
\text { Av: Голова Борисфена } \\
\text { (річкового божества) } \\
\text { вліво. } \\
\text { Rv: } 3 \text { права напис ОАВIO, } \\
\text { по центру поля монети } \\
\text { горит, зліва від нього } \\
\text { парадна сокира за нею } \\
\text { диферент \#88 }\end{array}$ & $\begin{array}{l}224 \text { р. до. н.е. } \\
\text { [Ніколаєв 2020: } \\
\text { 39]. }\end{array}$ & $\begin{array}{c}\text { Орлик, Коцур } \\
\& \text { Циганенко } \\
2019\end{array}$ & $\begin{array}{c}\text { Невідомо } \\
21 \text { мм. }\end{array}$ & $\begin{array}{l}\text { м.Городище, } \\
\text { Черкаський р-н, } \\
\text { Черкаська обл., } \\
2018 \text { р. }\end{array}$ \\
\hline 106 & $\begin{array}{c}\text { Ольвія, АE } \\
\text { Av: Голова Борисфена } \\
\text { (річкового божества) } \\
\text { вліво. } \\
\text { Rv: } 3 \text { права напис ОАВIO, } \\
\text { по центру поля монети } \\
\text { горит, зліва від нього } \\
\text { парадна сокира за нею } \\
\text { диферент \#88 }\end{array}$ & $\begin{array}{l}224 \text { р. до. н.е. } \\
\text { [Ніколаєв 2020: } \\
\text { 39]. }\end{array}$ & $\begin{array}{c}\text { Орлик, Коцур } \\
\& \text { Циганенко } \\
2019\end{array}$ & $\begin{array}{c}5,00 \\
18 \mathrm{mM} .\end{array}$ & $\begin{array}{l}\text { м.Городище, } \\
\text { Черкаський р-н, } \\
\text { Черкаська обл., } \\
2018 \text { р. }\end{array}$ \\
\hline 107 & $\begin{array}{c}\text { Ольвія, АE } \\
\text { Av: Голова Борисфена } \\
\text { (річкового божества) } \\
\text { вліво. } \\
\text { Rv: } 3 \text { права напис ОАВIО, } \\
\text { по центру поля монети } \\
\text { горит, зліва від нього } \\
\text { парадна сокира за нею } \\
\text { диферент \#88 } \\
\end{array}$ & $\begin{array}{l}224 \text { р. до. н.е. } \\
\text { [Ніколаєв 2020: } \\
\text { 39]. }\end{array}$ & $\begin{array}{c}\text { Орлик, Коцур } \\
\& \text { Циганенко } \\
2019\end{array}$ & $\begin{array}{c}5,25 \\
19 \text { мм. }\end{array}$ & $\begin{array}{l}\text { м.Городище, } \\
\text { Черкаський р-н, } \\
\text { Черкаська обл., } \\
2018 \text { р. }\end{array}$ \\
\hline 108 & $\begin{array}{c}\text { Ольвія, АE } \\
\text { Av: Голова Борисфена } \\
\text { (річкового божества) } \\
\text { вліво. } \\
\text { Rv: } 3 \text { права напис ОАВIO, } \\
\text { по центру поля монети } \\
\text { горит, зліва від нього } \\
\text { парадна сокира за нею } \\
\text { диферент \#90 }\end{array}$ & $\begin{array}{l}221 \text { р. до. н.е. } \\
\text { [Ніколаєв 2020: } \\
\text { 39]. }\end{array}$ & $\begin{array}{c}\text { Орлик, Коцур } \\
\& \text { Циганенко } \\
2019\end{array}$ & $\begin{array}{c}5,92 \\
19 \text { мм. }\end{array}$ & $\begin{array}{l}\text { м.Городище, } \\
\text { Черкаський р-н, } \\
\text { Черкаська обл., } \\
2018 \text { р. }\end{array}$ \\
\hline 109 & $\begin{array}{c}\text { Ольвія, АE } \\
\text { Av: Голова Борисфена } \\
\text { (річкового божества) } \\
\text { вліво. } \\
\text { Rv: } 3 \text { права напис ОАВІО, } \\
\text { по центру поля монети } \\
\text { горит, зліва від нього } \\
\text { парадна сокира за нею } \\
\text { диферент \#91 }\end{array}$ & $\begin{array}{l}220 \text { р. до. н.е. } \\
\text { [Ніколаєв 2020: } \\
\text { 39]. }\end{array}$ & $\begin{array}{c}\text { Орлик, Коцур } \\
\& \text { Циганенко } \\
2019\end{array}$ & $\begin{array}{c}\text { Невідомо } \\
19 \text { мм. }\end{array}$ & $\begin{array}{c}\text { м.Городище, } \\
\text { Черкаський р-н, } \\
\text { Черкаська обл., } \\
2018 \text { р. }\end{array}$ \\
\hline 110 & $\begin{array}{c}\text { Ольвія, АE } \\
\text { Аv: Голова Борисфена } \\
\text { (річкового божества) } \\
\text { вліво. } \\
\text { Rv: } 3 \text { права напис ОАВIО, } \\
\text { по центру поля монети } \\
\text { горит, зліва від нього } \\
\text { парадна сокира за нею } \\
\text { диферент \#91 }\end{array}$ & $\begin{array}{l}220 \text { р. до. н.е. } \\
\text { [Ніколаєв 2020: } \\
\text { 39]. }\end{array}$ & $\begin{array}{c}\text { Орлик, Коцур } \\
\& \text { Циганенко } \\
2019\end{array}$ & $\begin{array}{c}\text { Невідомо } \\
19 \text { мм. }\end{array}$ & $\begin{array}{l}\text { м.Городище, } \\
\text { Черкаський р-н, } \\
\text { Черкаська обл., } \\
2018 \text { р. }\end{array}$ \\
\hline 111 & $\begin{array}{c}\text { Ольвія, АE } \\
\text { Av: Голова Борисфена } \\
\text { (річкового божества) } \\
\text { вліво. } \\
\text { Rv: } 3 \text { права напис ОАВІО, } \\
\text { по центру поля монети } \\
\text { горит, зліва від нього } \\
\text { парадна сокира за нею } \\
\text { диферент \#91 або } 92\end{array}$ & $\begin{array}{l}220 \text { р. до. н.е. } \\
\text { [Ніколаєв 2020: } \\
\text { 39]. }\end{array}$ & $\begin{array}{c}\text { Орлик, Коцур } \\
\& \text { Циганенко } \\
2019\end{array}$ & $\begin{array}{c}6,85 \\
19 \text { мм. }\end{array}$ & $\begin{array}{l}\text { м.Городище, } \\
\text { Черкаський р-н, } \\
\text { Черкаська обл., } \\
2018 \text { p. }\end{array}$ \\
\hline
\end{tabular}


Украӥнський нумізматичний щорічник. Вип. 5. Переяслав, 2021.

\begin{tabular}{|c|c|c|c|c|c|}
\hline 1 & 2 & 3 & 4 & 5 & 6 \\
\hline 112 & $\begin{array}{c}\text { Ольвія, АE } \\
\text { Av: Голова Борисфена } \\
\text { (річкового божества) вліво. } \\
\text { Rv: } 3 \text { права напис ОАВІО, } \\
\text { по центру поля монети } \\
\text { горит, зліва від нього } \\
\text { парадна сокира за нею } \\
\text { диферент МтI } \\
\text { (див. Рис. 1.24) }\end{array}$ & $\begin{array}{c}\text { Близько } \\
226 \text { р. до н.е. } \\
\text { [Николаев 2015: } \\
\text { 220]. }\end{array}$ & $\begin{array}{c}\text { Орлик, Коцур } \\
\text { \& Циганенко } \\
2019\end{array}$ & $\begin{array}{l}4,49 \text { г. } \\
22 \times 20 \\
\text { мм. }\end{array}$ & $\begin{array}{l}\text { м.Городище, } \\
\text { Черкаський р-н, } \\
\text { Черкаська обл., } \\
2018 \text { р. }\end{array}$ \\
\hline 113 & $\begin{array}{c}\text { Ольвія, } \mathbf{A E} \\
\text { Av: Голова Борисфена } \\
\text { (річкового божества) вліво. } \\
\text { Rv: } з \text { права напис ОАВIO, } \\
\text { по центру поля монети } \\
\text { горит, зліва від нього } \\
\text { парадна сокира за нею } \\
\text { диферент МА } \\
\text { (див. Рис. 1.25) } \\
\end{array}$ & $\begin{array}{l}\text { 232-219 рр. до. н.е. } \\
\text { [Ніколаєв 2020: } \\
\text { 39]. }\end{array}$ & Орлик 2020-b & $\begin{array}{l}6,55 \\
21,5 \times 20 \mathrm{M} \\
\text { м. }\end{array}$ & $\begin{array}{c}\text { Знайдений поблизу } \\
\text { впадіння р. Бовтиш у } \\
\text { р. Тясмин, с. Івангород, } \\
\text { Олександрівська } \\
\text { селищна громада, } \\
\text { Кропивницький р-н, } \\
\text { Кіровоградська обл., } \\
2019 \text { р. }\end{array}$ \\
\hline 114 & $\begin{array}{c}\text { Ольвія, АE } \\
\text { Av: Голова Борисфена } \\
\text { (річкового божества) вліво. } \\
\text { Rv: } 3 \text { права напис ОАВIO, } \\
\text { по центру поля монети } \\
\text { горит, зліва від нього } \\
\text { парадна сокира за нею } \\
\text { диферент (не можливо } \\
\text { визначити через дефект } \\
\text { карбування, зокрема } \\
\text { зміщений штемпель) }\end{array}$ & & $\begin{array}{c}\text { Орлик, Коцур } \\
\text { \& Циганенко } \\
2019\end{array}$ & Невідомо & $\begin{array}{c}\text { м.Городище, } \\
\text { Черкаський р-н, } \\
\text { Черкаська обл., } \\
2018 \text { р. }\end{array}$ \\
\hline 115 & $\begin{array}{c}\text { Ольвія, АE } \\
\text { Av: Голова Борисфена } \\
\text { (річкового божества) вліво. } \\
\text { Rv: } 3 \text { права напис ОАВIO, } \\
\text { по центру поля монети } \\
\text { горит, зліва від нього } \\
\text { парадна сокира за нею } \\
\text { диферент (не можливо } \\
\text { визначити через } \\
\text { незадовільний стан } \\
\text { збереження монети) } \\
\end{array}$ & & $\begin{array}{c}\text { Не } \\
\text { опубліковано }\end{array}$ & Невідомо & $\begin{array}{c}\text { с. Жаботин, } \\
\text { Миха́йлівська сільська } \\
\text { ОТГ, Черкаський р-н, } \\
\text { Черкаська обл., } 2021 \text { р. }\end{array}$ \\
\hline 116 & $\begin{array}{c}\text { Ольвія, } \mathbf{A E} \\
\text { Аv: Голова Борисфена } \\
\text { (річкового божества) вліво. } \\
\text { Rv: } 3 \text { права напис О^ВIO, } \\
\text { по центру поля монети } \\
\text { горит, зліва від нього } \\
\text { парадна сокира за нею } \\
\text { диферент (не можливо } \\
\text { визначити через } \\
\text { незадовільний стан } \\
\text { збереження монети) } \\
\end{array}$ & & Ляшко 2017-а & $\begin{array}{l}9,30 \text { г. } \\
22 \text { мм. }\end{array}$ & $\begin{array}{c}\text { с. Райгород, } \\
\text { Михайлівська сільська } \\
\text { ОТГ, Черкаський р-н, } \\
\text { Черкаська обл., } \\
2010 \text { р. }\end{array}$ \\
\hline 117 & $\begin{array}{c}\text { Ольвія, } \mathbf{A E} \\
\text { Av: Голова Борисфена } \\
\text { (річкового божества) вліво. } \\
\text { Rv: з права напис ОАВIO, } \\
\text { по центру поля монети } \\
\text { горит, зліва від нього } \\
\text { парадна сокира за нею } \\
\text { диферент (не можливо } \\
\text { визначити через дефект } \\
\text { карбування, зокрема } \\
\text { зміщений штемпель) } \\
\end{array}$ & & $\begin{array}{c}\text { Не } \\
\text { опубліковано }\end{array}$ & $\begin{array}{c}8,20 \text { г. } \\
\text { Невідомо }\end{array}$ & $\begin{array}{c}\text { Знайдений поблизу } \\
\text { впадіння р. Бовтиш у } \\
\text { p. Тясмин, с. Івангород, } \\
\text { Олександрівська } \\
\text { селищна громада, } \\
\text { Кропивницький р-н, } \\
\text { Кіровоградська обл., } \\
2019 \text { р. }\end{array}$ \\
\hline
\end{tabular}


The Ukrainian Numismatic Annual. Issue 5, Pereiaslav, 2021.

\begin{tabular}{|c|c|c|c|c|c|}
\hline 1 & 2 & 3 & 4 & 5 & 6 \\
\hline 118 & $\begin{array}{c}\text { Ольвія, АE } \\
\text { Аv: Голова Борисфена } \\
\text { (річкового божества) } \\
\text { вліво. } \\
\text { Rv: з права напис ОАВІО, } \\
\text { по центру поля монети } \\
\text { горит, зліва від нього } \\
\text { парадна сокира за нею } \\
\text { диферент (не можливо } \\
\text { визначити через } \\
\text { незадовільний стан } \\
\text { збереження монети) }\end{array}$ & & $\begin{array}{c}\mathrm{He} \\
\text { опубліковано }\end{array}$ & $\begin{array}{c}\text { 7,80 г. } \\
\text { Невідомо }\end{array}$ & $\begin{array}{c}\text { Знайдений поблизу } \\
\text { впадіння р. Бовтиш у } \\
\text { р. Тясмин, с. Івангород, } \\
\text { Олександрівська } \\
\text { селищна громада, } \\
\text { Кропивницький р-н, } \\
\text { Кіровоградська обл., } \\
2019 \text { р. }\end{array}$ \\
\hline 119 & $\begin{array}{c}\text { Ольвія, } \mathbf{A E} \\
\text { Аv: Голова Борисфена } \\
\text { (річкового божества) } \\
\text { вліво. } \\
\text { Rv: } 3 \text { права напис ОАВІО, } \\
\text { по центру поля монети } \\
\text { горит, зліва від нього } \\
\text { парадна сокира за нею } \\
\text { диферент (не можливо } \\
\text { визначити через } \\
\text { незадовільний стан } \\
\text { збереження монети) }\end{array}$ & & $\begin{array}{c}\text { Не } \\
\text { опубліковано }\end{array}$ & $\begin{array}{l}10,31 \text { г. } \\
21 \text { мм. }\end{array}$ & $\begin{array}{c}\text { Знайдений поблизу } \\
\text { впадіння р. Бовтиш у } \\
\text { р. Тясмин, с. Івангород, } \\
\text { Олександрівська } \\
\text { селищна громада, } \\
\text { Кропивницький р-н, } \\
\text { Кіровоградська обл., } \\
2019 \text { р. }\end{array}$ \\
\hline 120 & $\begin{array}{c}\text { Ольвія, АE } \\
\text { Av: Голова Борисфена } \\
\text { (річкового божества) } \\
\text { вліво. } \\
\text { Rv: з права напис ОАВІО, } \\
\text { по центру поля монети } \\
\text { горит, зліва від нього } \\
\text { парадна сокира за нею } \\
\text { диферент (не можливо } \\
\text { визначити через } \\
\text { незадовільний стан } \\
\text { збереження монети) }\end{array}$ & & $\begin{array}{c}\text { Не } \\
\text { опубліковано }\end{array}$ & $\begin{array}{l}7,28 \text { г. } \\
21 \text { мм. }\end{array}$ & $\begin{array}{c}\text { Знайдений поблизу } \\
\text { впадіння р. Бовтиш у } \\
\text { р. Тясмин, с. Івангород, } \\
\text { Олександрівська } \\
\text { селищна громада, } \\
\text { Кропивницький р-н, } \\
\text { Кіровоградська обл., } \\
2019 \text { р. }\end{array}$ \\
\hline 121 & $\begin{array}{c}\text { Ольвія, АE } \\
\text { Av: Голова Борисфена } \\
\text { (річкового божества) } \\
\text { вліво. } \\
\text { Rv: } 3 \text { права напис ОАВІО, } \\
\text { по центру поля монети } \\
\text { горит, зліва від нього } \\
\text { парадна сокира за нею } \\
\text { диферент (не можливо } \\
\text { визначити через } \\
\text { незадовільний стан } \\
\text { збереження монети) } \\
\end{array}$ & & $\begin{array}{c}\text { Не } \\
\text { опубліковано }\end{array}$ & $\begin{array}{l}7,61 \text { г. } \\
21 \text { мм. }\end{array}$ & $\begin{array}{c}\text { Знайдений поблизу } \\
\text { впадіння р. Бовтиш у } \\
\text { р. Тясмин, с. Івангород, } \\
\text { Олександрівська } \\
\text { селищна громада, } \\
\text { Кропивницький р-н, } \\
\text { Кіровоградська обл., } \\
2019 \text { р. }\end{array}$ \\
\hline 122 & $\begin{array}{c}\text { Ольвія, АE } \\
\text { Аv: Голова Борисфена } \\
\text { (річкового божества) } \\
\text { вліво. } \\
\text { Rv: } 3 \text { права напис ОАВІО, } \\
\text { по центру поля монети } \\
\text { горит, зліва від нього } \\
\text { парадна сокира за нею } \\
\text { диферент (не можливо } \\
\text { визначити через } \\
\text { незадовільний стан } \\
\text { збереження монети) }\end{array}$ & & $\begin{array}{c}\text { Не } \\
\text { опубліковано }\end{array}$ & $\begin{array}{l}8,41 \text { г. } \\
21 \text { мм. }\end{array}$ & $\begin{array}{c}\text { Знайдений поблизу } \\
\text { впадіння р. Бовтиш у } \\
\text { р. Тясмин, с. Івангород, } \\
\text { Олександрівська } \\
\text { селищна громада, } \\
\text { Кропивницький р-н, } \\
\text { Кіровоградська обл., } \\
2019 \text { р. }\end{array}$ \\
\hline
\end{tabular}


Украӥнський нумізматичний щчорічник. Вип. 5. Переяслав, 2021.

\begin{tabular}{|c|c|c|c|c|c|}
\hline 1 & 2 & 3 & 4 & 5 & 6 \\
\hline 123 & $\begin{array}{c}\text { Ольвія, АE } \\
\text { Av: Голова Борисфена } \\
\text { (річкового божества) } \\
\text { вліво. } \\
\text { Rv: з права напис ОАВІО, } \\
\text { по центру поля монети } \\
\text { горит, зліва від нього } \\
\text { парадна сокира за нею } \\
\text { диферент (не можливо } \\
\text { визначити через } \\
\text { незадовільний стан } \\
\text { збереження монети) }\end{array}$ & & $\begin{array}{c}\text { Не } \\
\text { опубліковано }\end{array}$ & $\begin{array}{l}8,43 \text { г. } \\
21 \text { мм. }\end{array}$ & $\begin{array}{c}\text { Знайдений поблизу } \\
\text { впадіння р. Бовтиш у } \\
\text { р. Тясмин, с. Івангород, } \\
\text { Олександрівська } \\
\text { селищна громада, } \\
\text { Кропивницький р-н, } \\
\text { Кіровоградська обл., } \\
2019 \text { р. }\end{array}$ \\
\hline 124 & $\begin{array}{c}\text { Ольвія, } \mathbf{A E} \\
\text { Av: Голова Борисфена } \\
\text { (річкового божества) } \\
\text { вліво. } \\
\text { Rv: з права напис ОАВІО, } \\
\text { по центру поля монети } \\
\text { горит, зліва від нього } \\
\text { парадна сокира за нею } \\
\text { диферент (не можливо } \\
\text { визначити через } \\
\text { незадовільний стан } \\
\text { збереження монети) }\end{array}$ & & $\begin{array}{c}\text { Не } \\
\text { опубліковано }\end{array}$ & $\begin{array}{c}7,83 \text { г. } \\
22 \times 17 \\
\text { мм. }\end{array}$ & $\begin{array}{c}\text { Знайдений поблизу } \\
\text { впадіння р. Бовтиш у } \\
\text { р. Тясмин, с. Івангород, } \\
\text { Олександрівська } \\
\text { селищна громада, } \\
\text { Кропивницький р-н, } \\
\text { Кіровоградська обл., } \\
2019 \text { р. }\end{array}$ \\
\hline 125 & $\begin{array}{c}\text { Ольвія, АE } \\
\text { Av: Голова Геліоса в } \\
\text { анфас } \\
\text { Rv: ОА. Дві з'єднані } \\
\text { протоми коней } \\
\text { Монета має отвір. }\end{array}$ & $\begin{array}{c}\text { 210-200 pр. до н.е. } \\
\text { Анохин 2011: } \\
\text { \#449 }\end{array}$ & $\begin{array}{l}\text { forum.violity.co } \\
\mathrm{m}\end{array}$ & $\begin{array}{l}23 \times 19 \\
\text { мм. }\end{array}$ & $\begin{array}{c}\text { с. Цибулеве, } \\
\text { Дмитрівська сільська } \\
\text { громада, } \\
\text { Кропивницький р-н, } \\
\text { Кіровоградська обл. }\end{array}$ \\
\hline 126 & $\begin{array}{c}\text { Херсонес, } \mathbf{A E} \\
\text { Аv: Голова Діви в } \\
\text { кекрифалі вправо. } \\
\text { Rv: Морда лева в фас, } \\
\text { внизу палиця вліво, нижче } \\
\text { ХЕР } \\
\text { Монета має отвір. } \\
\text { (див. Рис. } 1.28 \text { ) } \\
\end{array}$ & $\begin{array}{c}\text { 385-380 pр. до н.е. } \\
\text { Анохин 2011: } \\
\text { \#631 }\end{array}$ & $\begin{array}{l}\text { forum.violity.co } \\
\mathrm{m}\end{array}$ & $\begin{array}{c}6,2 \\
20 \mathrm{Mм} .\end{array}$ & $\begin{array}{c}\text { с.Ружичево, } \\
\text { Олександрівська } \\
\text { селищна громада, } \\
\text { Кропивницький р-н, } \\
\text { Кіровоградська обл., } \\
2015 \text { р. }\end{array}$ \\
\hline 127 & $\begin{array}{c}\text { Херсонес, АE } \\
\text { Аv: Діва з факелом в } \\
\text { колісниці, запряженій } \\
\text { чотирма кіньми вправо. } \\
\text { Rv: Оголений воїн } \\
\text { схилений на праве коліно, } \\
\text { вліво, на голові шолом в } \\
\text { правиці тримає спис, у } \\
\text { лівій руці щит, XЕР } \\
\text { (див. Рис. 1.27) } \\
\end{array}$ & $\begin{array}{c}\text { 350-330 pр. до н.е. } \\
\text { Анохин 2011: } \\
\text { \#658 }\end{array}$ & $\begin{array}{l}\text { auction.violity } \\
\text { romanumismatic } \\
\text { s.com }\end{array}$ & $\begin{array}{l}4,76 \text { г. } \\
20 \text { мм. }\end{array}$ & $\begin{array}{c}\text { У лісі поблизу с. Зелена } \\
\text { Діброва, Вільшанська } \\
\text { селищна громада, } \\
\text { Черкаський р-н, } \\
\text { Черкаська обл., } \\
2018 \text { р. }\end{array}$ \\
\hline 128 & $\begin{array}{c}\text { Херсонес, } \mathbf{A E} \\
\text { Аv: Діва з факелом в } \\
\text { колісниці, запряженій } \\
\text { двома кіньми вправо. } \\
\text { Rv: Лев зі списом в пащі } \\
\text { вліво, зверху ПА, в обрізі } \\
\text { ХЕР } \\
\text { (див. Рис. } 1.26) \\
\end{array}$ & $\begin{array}{c}\text { Близько } 350 \text { р. до } \\
\text { н.е. } \\
\text { Анохин } 2011: \\
\# 659\end{array}$ & $\begin{array}{c}\text { Не } \\
\text { опубліковано }\end{array}$ & $\begin{array}{l}3,42 \text { г. } \\
15 \text { мм. }\end{array}$ & $\begin{array}{c}\text { Поблизу хутора Лісове, } \\
\text { Михайлівська сільська } \\
\text { ОТГ, Черкаський р-н, } \\
\text { Черкаська обл., } \\
2020\end{array}$ \\
\hline 129 & $\begin{array}{c}\text { Av: Діва з факелом в } \\
\text { колісниці, запряженій } \\
\text { чотирма кіньми вправо, } \\
\text { справа вгорі НР. } \\
\text { Rv: Оголений воїн } \\
\text { схилений на праве коліно, } \\
\text { вліво, на голові шолом в } \\
\text { правиці тримає спис, у } \\
\text { лівій руці щит, ХЕР }\end{array}$ & $\begin{array}{c}\text { 350-330 pр. до н.е. } \\
\text { Анохин 2011: } \\
\text { \#661 }\end{array}$ & facebook.com & Невідомо & $\begin{array}{c}\text { Знайдено в районі } \\
\text { с. Головківка, } \\
\text { Медведівська сільська } \\
\text { ОТГ, Черкаський р-н, } \\
\text { Черкаська обл.., } \\
2021 \text { р. }\end{array}$ \\
\hline
\end{tabular}


The Ukrainian Numismatic Annual. Issue 5, Pereiaslav, 2021.

\begin{tabular}{|c|c|c|c|c|c|}
\hline 1 & 2 & 3 & 4 & 5 & 6 \\
\hline 130 & $\begin{array}{c}\text { Херсонес, } \mathbf{A E} \\
\text { Аv: Діва, яка вражає } \\
\text { списом у правиці лань } \\
\text { вліво, в лівій руці лук; } \\
\text { справа над карбування із } \\
\text { зображенням дельфіна, } \\
\text { нижче ХЕР } \\
\text { Rv: Бик на палиці вліво, } \\
\text { внизу ім'я - } \\
<\Delta>\text { ІАГ <ОРА>, лук і } \\
\text { сагайдак }\end{array}$ & $\begin{array}{l}\text { 300-290 pр. до н.е. } \\
\text { Анохин 2011: } \\
\text { \#701 }\end{array}$ & Шостопал 2007 & $\begin{array}{l}18 \times 21 \\
\text { MM. }\end{array}$ & $\begin{array}{c}\text { с. Леськи Черкаський р- } \\
\text { н, Черкаська обл., } \\
\text { узбережжя р. Дніпро, } \\
\text { дамба. } 2006 \text { p. }\end{array}$ \\
\hline 131 & 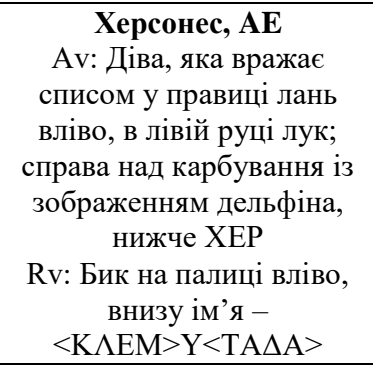 & $\begin{array}{l}\text { 300-290 pр. до н.е. } \\
\text { Анохин 2011: } \\
\text { \#702 }\end{array}$ & $\begin{array}{c}\text { Не } \\
\text { опубліковано }\end{array}$ & $\begin{array}{l}\text { Невідомо } \\
18 \times 21 \\
\text { мм. }\end{array}$ & $\begin{array}{c}\text { Випадкова знахідка, } \\
\text { с.Леськи Черкаський р- } \\
\text { н, Черкаська обл., } \\
\text { узбережжя р. Дніпро, } \\
\text { дамба. } 2001 \text { р. }\end{array}$ \\
\hline 132 & $\begin{array}{c}\text { Херсонес, } \mathbf{A E} \\
\text { Av: зображено портрет } \\
\text { чоловіка у лавровому } \\
\text { вінку вправо } \\
\text { Rv: } \\
\text { зображення жінки у } \\
\text { довгому вбранні, з луком } \\
\text { у правій руці, ліва рука } \\
\text { зігнута у лікті і піднята } \\
\text { вгору; напис «Х» (справа), } \\
\text { «ТNР» (зліва). }\end{array}$ & $\begin{array}{c}\text { 63-47 pp. } \\
\text { до н.е. } \\
\text { Туровский } 2014\end{array}$ & Шостопал 2007 & Невідомо & $\begin{array}{c}\text { Випадкова знахідка, } \\
\text { с. Суботів, Чигиринська } \\
\text { міська ОТГ, Черкаський } \\
\text { р-н, Черкаська обл., } \\
2003 \text { р. }\end{array}$ \\
\hline 133 & $\begin{array}{c}\text { Пантикапей, } \mathbf{A E} \\
\text { Av: Голова бородатого } \\
\text { сатира вправо } \\
\text { Rv: Протомой Грифона, } \\
\text { нижче осетер, по бокам } \\
\text { ПАN } \\
\end{array}$ & $\begin{array}{l}\text { 320-310 рр. до н.е. } \\
\text { Анохин 2011: } \\
\text { \#1023 }\end{array}$ & $\begin{array}{l}\text { Шостопал } \\
2015, \text { с.26 }\end{array}$ & Невідомо & $\begin{array}{l}\text { Територія колишнього } \\
\text { Чигиринського р-ну, } \\
\text { Черкаська обл., } \\
\text { До } 2015 \text { р. }\end{array}$ \\
\hline 134 & $\begin{array}{c}\text { Пантикапей, AE } \\
\text { Av: Голова бородатого } \\
\text { сатира вправо } \\
\text { Rv: Протомой Грифона, } \\
\text { нижче осетер, по бокам } \\
\text { ПАN } \\
\text { Монета має отвір } \\
\end{array}$ & $\begin{array}{l}\text { 320-310 pр. до н.е. } \\
\text { Анохин 2011: } \\
\# 1023\end{array}$ & $\begin{array}{c}\text { Не } \\
\text { опубліковано }\end{array}$ & $\begin{array}{l}5,55 \text { г. } \\
21 \text { мм. }\end{array}$ & $\begin{array}{c}\text { Поблизу с. Підлісне } \\
\text { Олександрівська } \\
\text { селищна громада, } \\
\text { Кропивницький р-н, } \\
\text { Кіровоградська обл., } \\
2020 \text { р. }\end{array}$ \\
\hline 135 & $\begin{array}{c}\text { Пантикапей, } \mathbf{A E} \\
\text { Av: Голова бородатого } \\
\text { сатира вправо } \\
\text { Rv: Протомой Грифона, } \\
\text { нижче осетер, по бокам } \\
\text { ПАN } \\
\text { Монета має отвір }\end{array}$ & $\begin{array}{l}\text { 320-310 pр. до н.е. } \\
\text { Анохин 2011: } \\
\# 1023\end{array}$ & $\begin{array}{c}\text { Не } \\
\text { опубліковано }\end{array}$ & $\begin{array}{l}5,33 \text { г. } \\
21 \text { мм. }\end{array}$ & $\begin{array}{c}\text { Поблизу с. Плішки, } \\
\text { Олександрівська } \\
\text { селищна громада, } \\
\text { Кропивницький р-н, } \\
\text { Кіровоградська обл., } \\
2021 \text { р. }\end{array}$ \\
\hline 136 & $\begin{array}{c}\text { Пантикапей, AE } \\
\text { Av: Голова бородатого } \\
\text { сатира вправо } \\
\text { Rv: Протомой Грифона, } \\
\text { нижче осетер, по бокам } \\
\text { ПАN } \\
\text { Монета має отвір }\end{array}$ & $\begin{array}{l}\text { 320-310 pр. до н.е. } \\
\text { Анохин 2011: } \\
\# 1023\end{array}$ & forum.violity & Невідомо & $\begin{array}{c}\text { с. Заломи, Дмитрівська } \\
\text { сільська громада, } \\
\text { Кропивницький р-н, } \\
\text { Кіровоградська обл. } \\
2021\end{array}$ \\
\hline 137 & $\begin{array}{c}\text { Пантикапей, AE } \\
\text { Av: Голова бородатого } \\
\text { сатира вправо } \\
\text { Rv: Протомой Грифона, } \\
\text { нижче осетер, по бокам } \\
\text { ПАN } \\
\end{array}$ & $\begin{array}{l}\text { 320-310 рр. до н.е. } \\
\text { Анохин 2011: } \\
\# 1023\end{array}$ & $\begin{array}{c}\text { Не } \\
\text { опубліковано }\end{array}$ & $\begin{array}{c}\text { 7,43 г. } \\
\text { Невідомо }\end{array}$ & $\begin{array}{c}\text { с. Макіївка, } \\
\text { Ротмістрівська сільська } \\
\text { ОТГ, Черкаський р-н, } \\
\text { Черкаська обл. } \\
\text { До } 2019 \text { р. }\end{array}$ \\
\hline
\end{tabular}


Украӥнський нумізматичний щорічник. Вип. 5. Переяслав, 2021.

\begin{tabular}{|c|c|c|c|c|c|}
\hline 1 & 2 & 3 & 4 & 5 & 6 \\
\hline 138 & $\begin{array}{c}\text { Керкінітида, АE } \\
\text { Аv: Скіф з сокирою, що } \\
\text { сидить на скелі вліво. } \\
\text { Зліва - <КЕРКІ> } \\
\text { Rv: Кінь вліво, внизу - } \\
\text { КА } \Lambda \text { ІП<...> }\end{array}$ & $\begin{array}{l}\text { 300-290 pр. до н.е. } \\
\text { Анохин 2011: } \\
\# 1023\end{array}$ & $\begin{array}{l}\text { Orlyk \& Orlyk } \\
2020\end{array}$ & $\begin{array}{l}6,45 \text { г. } \\
20 \text { мм. }\end{array}$ & $\begin{array}{l}\text { с. В'язівок, Вільша́нська } \\
\text { селищна громада, } \\
\text { Черкаський р-н, } \\
\text { Черкаська обл., у } \\
\text { верхній частині річки } \\
\text { Вільшанка, восени } \\
2019 \text { р. }\end{array}$ \\
\hline 139 & $\begin{array}{c}\text { Мізія, м. Кизік, El } \\
\text { Av:: Кабан стоїть на тунці } \\
\text { (вліво) } \\
\text { Rv: quadratum incusum } \\
\text { (див. Рис. 1.29) } \\
\end{array}$ & $\begin{array}{l}\text { 550-475 рр. до н.е. } \\
\text { Von Fritze 1912: } 90\end{array}$ & Шостопал 2007 & Невідомо & $\begin{array}{l}\text { с. Медведівка, } \\
\text { Черкаський р-н, } \\
\text { Черкаська обл. }\end{array}$ \\
\hline 140 & $\begin{array}{c}\text { Мізія, м. Кизік, El } \\
\text { Аv:: оголений безбородий } \\
\text { юнак у коринфському } \\
\text { шоломі, вліво, схилений } \\
\text { на праве коліно, на лівій } \\
\text { руці висить лук, правицею } \\
\text { перевіряє стрілу, ззаду } \\
\text { тунець вертикально до } \\
\text { низу. } \\
\text { Rv: quadratum incusum } \\
\text { (див. Рис. 1.30) }\end{array}$ & $\begin{array}{l}\text { 550-475 pр. до н.е. } \\
\text { Von Fritze 1912: } \\
116\end{array}$ & Шостопал 2007 & Невідомо & $\begin{array}{l}\text { с. Медведівка, } \\
\text { Черкаський р-н, } \\
\text { Черкаська обл. }\end{array}$ \\
\hline 141 & $\begin{array}{c}\text { Мізія, м. Кизік, El } \\
\text { Аv:: Ніка присівши } \\
\text { просувається ліворуч, } \\
\text { голова звернена праворуч, } \\
\text { розправлені крила, і в } \\
\text { правій руці тримає тунця } \\
\text { за хвіст, а правою } \\
\text { притримує поділ іï хітону. } \\
\text { Rv: quadratum incusum } \\
\text { (див. Рис. 1.31) }\end{array}$ & $\begin{array}{l}\text { 550-475 pр. до н.е. } \\
\text { Von Fritze 1912: } \\
121 .\end{array}$ & Шостопал 2007 & Невідомо & $\begin{array}{l}\text { с. Медведівка, } \\
\text { Черкаський р-н, } \\
\text { Черкаська обл. }\end{array}$ \\
\hline 142 & $\begin{array}{c}\text { Мізія, м. Кизік, El } \\
\text { Аv:: Оголенй воїн з } \\
\text { бородою (вліво), } \\
\text { схилений на ліве коліно, в } \\
\text { правиці тримає півня, ліва } \\
\text { рука ззаду, знизу тунець } \\
\text { вліво. } \\
\text { Rv: quadratum incusum } \\
\text { (див. Рис. } 1.32 \text { ) }\end{array}$ & & Шостопал 2007 & Невідомо & $\begin{array}{l}\text { с. Медведівка, } \\
\text { Черкаський р-н, } \\
\text { Черкаська обл. }\end{array}$ \\
\hline 143 & $\begin{array}{c}\text { Мізія, м. Кизік, Еl } \\
\text { Av::Невідомо } \\
\text { Rv: quadratum incusum } \\
\end{array}$ & & Шостопал 2007 & Невідомо & $\begin{array}{l}\text { с. Медведівка, } \\
\text { Черкаський р-н, } \\
\text { Черкаська обл. }\end{array}$ \\
\hline 144 & $\begin{array}{c}\text { Мізія, м. Кизік, Еl } \\
\text { Av::Невідомо } \\
\text { Rv: quadratum incusum } \\
\end{array}$ & & Шостопал 2007 & Невідомо & $\begin{array}{l}\text { с. Медведівка, } \\
\text { Черкаський р-н, } \\
\text { Черкаська обл. }\end{array}$ \\
\hline 145 & $\begin{array}{c}\text { Мізія, м. Кизік, El } \\
\text { Av::Невідомо } \\
\text { Rv: quadratum incusum }\end{array}$ & & Шостопал 2007 & Невідомо & $\begin{array}{l}\text { с. Медведівка, } \\
\text { Черкаський р-н, } \\
\text { Черкаська обл. }\end{array}$ \\
\hline 146 & $\begin{array}{c}\text { Мізія, м. Кизік, Еl } \\
\text { Av::Невідомо } \\
\text { Rv: quadratum incusum }\end{array}$ & & Шостопал 2007 & Невідомо & $\begin{array}{l}\text { с. Медведівка, } \\
\text { Черкаський р-н, } \\
\text { Черкаська обл. }\end{array}$ \\
\hline 147 & $\begin{array}{c}\text { Мізія, м. Кизік, Еl } \\
\text { Av::Невідомо } \\
\text { Rv: quadratum incusum } \\
\end{array}$ & & Шостопал 2007 & Невідомо & $\begin{array}{l}\text { с. Медведівка, } \\
\text { Черкаський р-н, } \\
\text { Черкаська обл. }\end{array}$ \\
\hline 148 & $\begin{array}{c}\text { Мізія, м. Кизік, Еl } \\
\text { Av::Невідомо } \\
\text { Rv: quadratum incusum } \\
\end{array}$ & & Шостопал 2007 & Невідомо & $\begin{array}{l}\text { с. Медведівка, } \\
\text { Черкаський р-н, } \\
\text { Черкаська обл. }\end{array}$ \\
\hline 149 & $\begin{array}{c}\text { Мізія, м. Кизік, Еl } \\
\text { Av::Невідомо } \\
\text { Rv: quadratum incusum }\end{array}$ & & Шостопал 2007 & Невідомо & $\begin{array}{l}\text { с. Медведівка, } \\
\text { Черкаський р-н, } \\
\text { Черкаська обл. }\end{array}$ \\
\hline 150 & $\begin{array}{c}\text { Мізія, м. Кизік, Еl } \\
\text { Av::Невідомо } \\
\text { Rv: quadratum incusum }\end{array}$ & & Шостопал 2007 & Невідомо & $\begin{array}{l}\text { с. Медведівка, } \\
\text { Черкаський р-н, } \\
\text { Черкаська обл. }\end{array}$ \\
\hline
\end{tabular}


The Ukrainian Numismatic Annual. Issue 5, Pereiaslav, 2021.

\begin{tabular}{|c|c|c|c|c|c|}
\hline 1 & 2 & 3 & 4 & 5 & 6 \\
\hline 151 & $\begin{array}{c}\text { Мізія, м. Кизік, El } \\
\text { Av::Невідомо } \\
\text { Rv: quadratum incusum } \\
\end{array}$ & & Шостопал 2007 & Невідомо & $\begin{array}{l}\text { с. Медведівка, } \\
\text { Черкаський р-н, } \\
\text { Черкаська обл. }\end{array}$ \\
\hline 152 & $\begin{array}{c}\text { Мізія, м. Кизік, El } \\
\text { Av: немовлята Геракл та } \\
\text { Іфікл, котрі борються зі } \\
\text { зміями, внизу тунець } \\
\text { вліво. } \\
\text { Rv: quadratum incusum } \\
\text { (див. Рис. } 1.33 \text { ) }\end{array}$ & $\begin{array}{c}410-330 \text { рр. до } \\
\text { н.е. } \\
\text { Von Fritze 1912: } \\
\text { Bd. VII. S.2. } \\
\text { Taf.1.2. }\end{array}$ & Орлик 2021-b & $\begin{array}{l}15,91 \text { г. } \\
21 \times 17 \\
\text { мМ. }\end{array}$ & $\begin{array}{c}\text { с. Родниківка, } \\
\text { Олександрівська } \\
\text { селищна громада, } \\
\text { Кропивницький р-н, } \\
\text { Кіровоградська обл., } \\
2020 \text { р. }\end{array}$ \\
\hline 153 & $\begin{array}{l}\text { Перська держава } \\
\text { Ахеменідів, AV. } \\
\text { Av: } \\
\text { Rv: incuse punch } \\
\text { (див. Рис. 1.34) } \\
\end{array}$ & $\begin{array}{l}\text { Рубіж VI-V ст. до } \\
\text { н.е. }\end{array}$ & $\begin{array}{l}\text { Сальников, } \\
\text { Mielczarek }\end{array}$ & $\begin{array}{c}8,32 \\
17 \text { мм.о }\end{array}$ & $\begin{array}{c}\text { Балка на околиці } \\
\text { м. Слисаветрада } \\
\text { (сучасний } \\
\text { Кропивницький), } \\
\text { знахідки до } 1924 \text { р. }{ }^{1}\end{array}$ \\
\hline 154 & $\begin{array}{c}\text { Iстрія, AR } \\
\text { Av. Голови Діоскурів } \\
\text { Rv. ISTRIH, орел вліво на } \\
\text { дельфіні }\end{array}$ & $\begin{array}{l}\text { IV ст. до н.е. } \\
\text { SNG BM Black Sea } \\
\text { №237-238, 240- } \\
249,251-257\end{array}$ & $\begin{array}{c}\text { Не } \\
\text { опубліковано }\end{array}$ & Невідомо & $\begin{array}{c}\text { Між селами Калинівка } \\
\text { та Веселий Кут } \\
\text { Дмитрівська сільська } \\
\text { громада, } \\
\text { Кропивницький р-н, } \\
\text { Кіровоградська обл., } \\
2019 . \\
\end{array}$ \\
\hline 155 & $\begin{array}{c}\text { Македонія, АE } \\
\text { Av: Голова Аполона у } \\
\text { лавровому вінку вправо } \\
\text { Rv:Вершник вправо, } \\
\text { зверху напис ФІАІППІY }\end{array}$ & 359-323 рр. до н.е. & Ляшко 2017-а & $\begin{array}{l}6,45 \text { г. } \\
17 \text { мм. }\end{array}$ & $\begin{array}{c}\text { с. Райгород, } \\
\text { Михайлівська сільська } \\
\text { ОТГ, Черкаський р-н, } \\
\text { Черкаська обл., } \\
2017 \text { р. } \\
\end{array}$ \\
\hline 156 & $\begin{array}{c}\text { Македонія, AE } \\
\text { Av: Голова Аполона у } \\
\text { лавровому вінку вправо } \\
\text { Rv:Вершник вправо, } \\
\text { зверху напис ФІАIППІҮ }\end{array}$ & 359-323 рр. до н.е. & $\begin{array}{c}\text { Не } \\
\text { опубліковано }\end{array}$ & Невідомо & $\begin{array}{c}\text { с. Вдовичине, } \\
\text { Чигиринська міська } \\
\text { ОТГ, } \\
\text { Черкаський р-н, } \\
\text { Черкаська обл. } 2020 \text { р. }\end{array}$ \\
\hline 157 & $\begin{array}{c}\text { Македонія, AE } \\
\text { Av: Голова Аполона у } \\
\text { лавровому вінку вправо } \\
\text { Rv:Вершник вправо, } \\
\text { зверху напис ФIАIППIY } \\
\end{array}$ & 359-323 рр. до н.е. & facebook.com/ & $\begin{array}{l}6,88 \text { г. } \\
17 \text { мм }\end{array}$ & $\begin{array}{l}\text { м. Кропивницький, } \\
\text { берег р. Інгул } \\
2021\end{array}$ \\
\hline 158 & $\begin{array}{c}\text { Македонія, } \mathbf{A E} \\
\text { Аv: Голова Аполона у } \\
\text { лавровому вінку вправо } \\
\text { Rv:Вершник вліво, зверху } \\
\text { напис ФІАІППІҮ } \\
\text { (див. Рис. 1.35) } \\
\end{array}$ & 359-323 рр. до н.е. & $\begin{array}{c}\mathrm{He} \\
\text { опубліковано }\end{array}$ & $\begin{array}{c}\text { 7,06 г. } \\
17,5 \text { мм. }\end{array}$ & $\begin{array}{c}\text { с. Тарасівка, } \\
\text { Олександрівська } \\
\text { селищна громада, } \\
\text { Кропивницький р-н, } \\
\text { Кіровоградська обл., } \\
2016 \text { р. } \\
\end{array}$ \\
\hline 159 & $\begin{array}{c}\text { Македонія, АE } \\
\text { Av: Македонський щит. } \\
\text { Rv: В-А ліворуч і } \\
\text { праворуч від } \\
\text { македонського шолома-, } \\
\text { монограма П з точкою Y } \\
\text { внизу. } \\
\text { (див. Рис.1.36) } \\
\end{array}$ & 325-310 рр. до н.е. & $\begin{array}{c}\text { Не } \\
\text { опубліковано }\end{array}$ & $\begin{array}{l}4,69 \text { г. } \\
16 \text { мм. }\end{array}$ & $\begin{array}{c}\text { с. Оситняжка, } \\
\text { Кропивницький р-н, } \\
\text { Кіровоградська обл., } \\
\text { травень } 2020 \text { р. }\end{array}$ \\
\hline 160 & $\begin{array}{c}\text { Македонія, АE } \\
\text { Av: Македонський щит. } \\
\text { Rv: В-А ліворуч і } \\
\text { праворуч від } \\
\text { македонського шолома-, } \\
\text { монограма П з точкою Y } \\
\text { внизу. }\end{array}$ & 325-310 рр. до н.е. & $\begin{array}{c}\text { Не } \\
\text { опубліковано }\end{array}$ & $\begin{array}{l}4,05 \text { г. } \\
16 \text { мм. }\end{array}$ & $\begin{array}{c}\text { с.Підлісне, } \\
\text { Олександрівська } \\
\text { селищна громада, } \\
\text { Кропивницький р-н, } \\
\text { Кіровоградська обл., } \\
\text { січень } 2021 \text { р. }\end{array}$ \\
\hline
\end{tabular}

\footnotetext{
${ }^{1}$ Автор вдячний директору Одеського археологічного музею д.і.н., професору Ігорю Бруяко та старшому наукову співробітнику музею к.і.н. Дмитру Янову за надану інформацію і світлину монети, яка зберігається у фондах музею (інвентарний номер 52194).
} 
Украӥнський нумізматичний щорічник. Вип. 5. Переяслав, 2021.

\begin{tabular}{|c|c|c|c|c|c|}
\hline 1 & 2 & 3 & 4 & 5 & 6 \\
\hline 161 & $\begin{array}{c}\text { Віфінія, Нікомедія АЕ . } \\
\text { Прусій І Кульгавий } \\
\text { Nikomedia } \\
\text { Av: Голова Аполлона у } \\
\text { вінку праворуч. } \\
\text { Rv: BA I } \Lambda \text { } \Omega \Sigma \text { / } \\
\text { ПРоY IOY, легенда вниз } \\
\text { праворуч та ліворуч від } \\
\text { лука та сагайдака } \\
\text { (див. Рис. } 1.37 \text { ) }\end{array}$ & $\begin{array}{c}\text { близько 228-182 } \\
\text { рр. до н.е. }\end{array}$ & forum.violity & $\begin{array}{l}4.17 \text { г. } \\
20 \text { мм. }\end{array}$ & $\begin{array}{l}\text { Поблизу с. Кудашево, } \\
\text { Чигиринська міська } \\
\text { ОТГ, Черкаський р-н, } \\
\text { Черкаська обл., на межі } \\
3 \text { Кіровоградською } \\
\text { областю } 2020 \text { р. }\end{array}$ \\
\hline 162 & 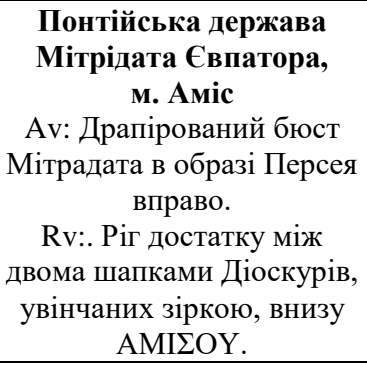 & $\begin{array}{l}\text { 125-100 pp. до н.е. } \\
\text { SNG BM Black Sea } \\
\quad \# \# 1130-1133\end{array}$ & $\begin{array}{c}\text { Не } \\
\text { опубліковано }\end{array}$ & $\begin{array}{l}2,97 \text { г. } \\
15 \text { мм. }\end{array}$ & $\begin{array}{c}\text { с. Козирівка, } \\
\text { Новгородківська } \\
\text { селищна громада, } \\
\text { Кропивницький р-н, } \\
\text { Кіровоградська обл. }\end{array}$ \\
\hline 163 & $\begin{array}{c}\text { Понтійська держава } \\
\text { Мітрідата Євпатора, } \\
\text { м. Таулара АE } \\
\text { Av: голова Зевса вправо. } \\
\text { Rv: Орел на блискавці, } \\
\text { зліва від орла диферент, } \\
\text { під блискавицею } \\
\text { ТАҮ АРР } 2 N \\
\text { (див. Рис. 1.38) } \\
\end{array}$ & $\begin{array}{l}\text { 100-85 pр. до н.е. } \\
\text { SNG BM Black Sea } \\
\text { \#\#1288-1289 }\end{array}$ & Орлик 2020-а & $\begin{array}{l}20 \text { г. } \\
30 \text { мм. }\end{array}$ & $\begin{array}{c}\text { с. Лубенці, } \\
\text { Миха́йлівська сільська } \\
\text { ОТГ, Черкаський р-н, } \\
\text { Черкаська обл. }{ }^{1}\end{array}$ \\
\hline 164 & $\begin{array}{c}\text { Понтійська держава } \\
\text { Мітрідата Євпатора, } \\
\text { Av: голова Зевса вправо. } \\
\text { Rv: Орел на блискавці. }\end{array}$ & 100-85 рр. до н.е. & $\begin{array}{c}\text { Не } \\
\text { опубліковано }\end{array}$ & Невідомо & $\begin{array}{c}\text { с. Лубенці, } \\
\text { Миха́йлівська сільська } \\
\text { ОТГ, Черкаський р-н, } \\
\text { Черкаська обл. }\end{array}$ \\
\hline 165 & $\begin{array}{c}\text { Понтійська держава } \\
\text { Мітрідата Свпатора, } \\
\text { м. Аміс AE } \\
\text { Av: Голова Ареса у } \\
\text { «крилатому» шоломі } \\
\text { вправо. } \\
\text { Rv: Меч у піхвах } \\
\text { АMI- } \mathrm{OY} \\
\end{array}$ & $\begin{array}{l}\text { 100-85 pр. до н.е. } \\
\text { SNG BM Black Sea } \\
\text { \#\#1147-1149 }\end{array}$ & $\begin{array}{c}\text { Не } \\
\text { опубліковано }\end{array}$ & Невідомо & $\begin{array}{c}\text { с. Медведівка, } \\
\text { Черкаський p-н, } \\
\text { Черкаська обл., } 2016 \text { p. }\end{array}$ \\
\hline 166 & $\begin{array}{c}\text { Понтійська держава } \\
\text { Мітрідата Євпатора, } \\
\text { м. Пантикапей } \\
\text { Av: Тринога } \\
\text { Rv: Зірка, між променями } \\
\text { напис П-А-N-T-I-K-A-П } \\
\end{array}$ & $\begin{array}{l}\text { 90-80 рр. до н.е. } \\
\text { Анохин 2011: } \\
\text { \#1123 }\end{array}$ & forum.violity & $\begin{array}{l}1,40 \text { г. } \\
14 \text { мм. }\end{array}$ & $\begin{array}{c}\text { с. Рублівка, } \\
\text { Чигиринська міська } \\
\text { ОТГ, Черкаський р-н, } \\
\text { Черкаська обл., } 2019 \text { р. }\end{array}$ \\
\hline 167 & $\begin{array}{c}\text { Понтійська держава } \\
\text { Мітрідата Свпатора, } \\
\text { Tiра, АE } \\
\text { Av: Голова Афіни в } \\
\text { коринфському шоломі } \\
\text { вправо. } \\
\text { Rv: TYP<A> Бик, що } \\
\text { буцається вліво }\end{array}$ & $\begin{array}{l}\text { 90-80 рр. до н.е. } \\
\text { Анохин 2011: \#57 }\end{array}$ & $\begin{array}{c}\text { Не } \\
\text { опубліковано }\end{array}$ & $\begin{array}{l}5,30 г \text {. } \\
21 \times 19 \\
\text { мм. }\end{array}$ & $\begin{array}{l}\text { Поблизу с. Іванівна, } \\
\text { Олександрівська } \\
\text { селищна громада, } \\
\text { Кропивницький р-н, } \\
\text { Кіровоградська обл., } \\
2019 \text { р. }\end{array}$ \\
\hline
\end{tabular}

${ }^{1}$ Автор вдячний Свгену Колісніченку за надану інформацію та світлину монети. 
The Ukrainian Numismatic Annual. Issue 5, Pereiaslav, 2021.

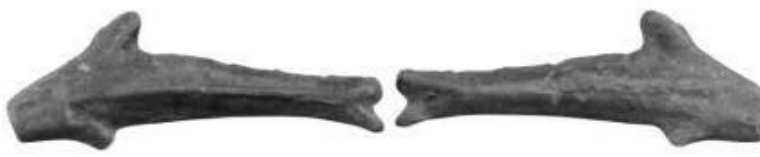

1

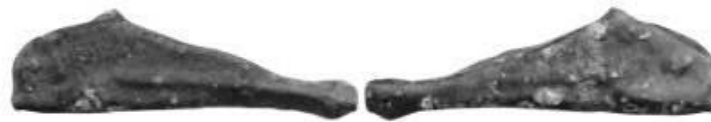

3

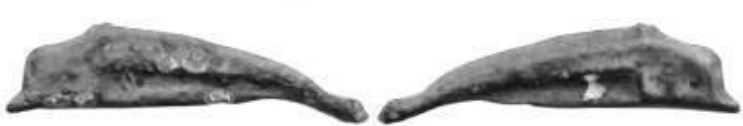

5

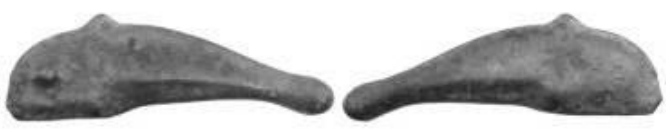

2

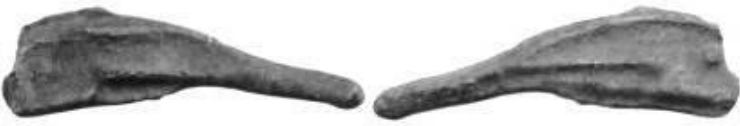

4

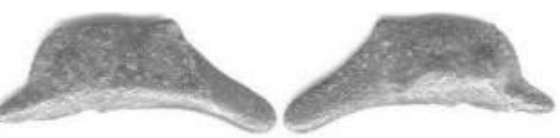

6

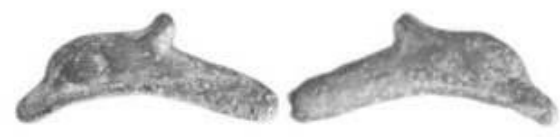

7
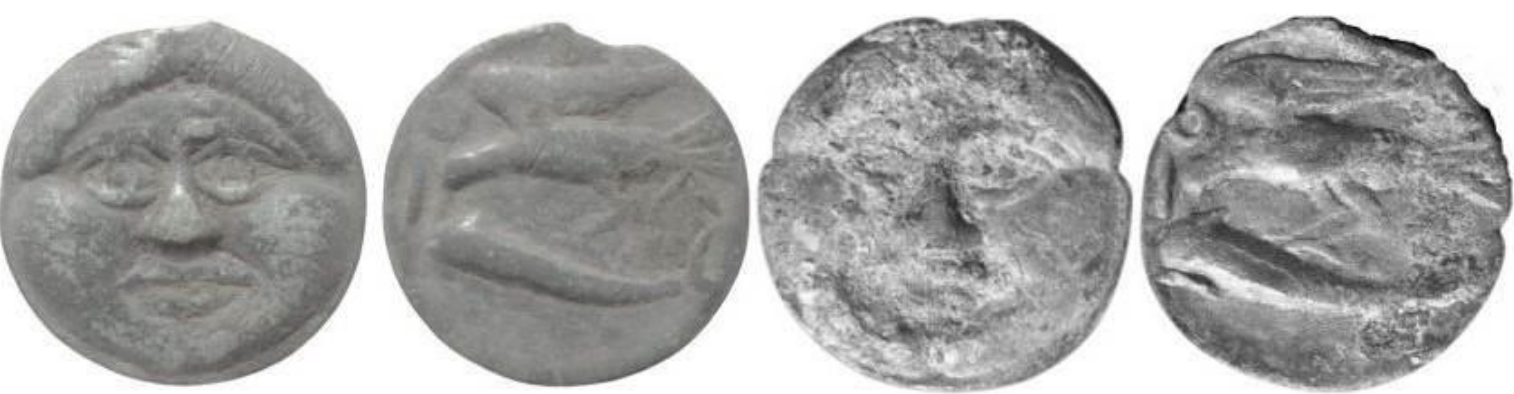

8

9

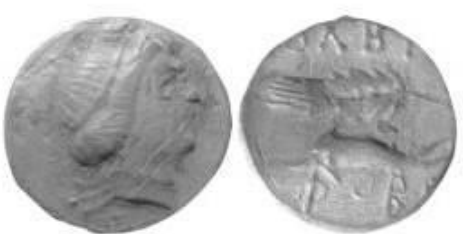

10

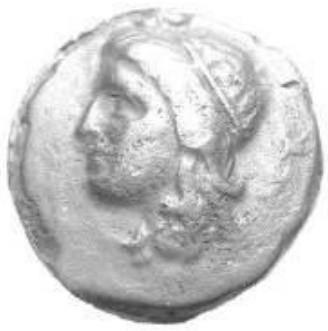

12

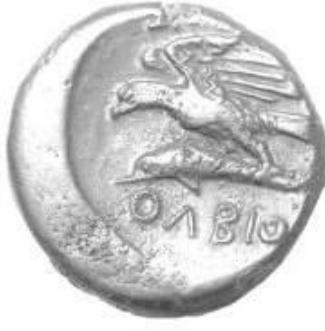

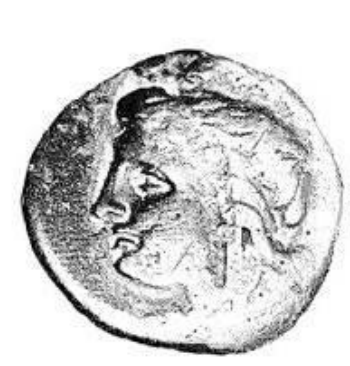

11

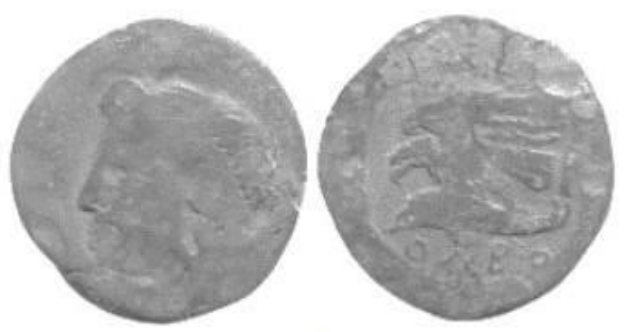

13 
Украӥнський нумізматичний щорічник. Вип. 5. Переяслав, 2021.

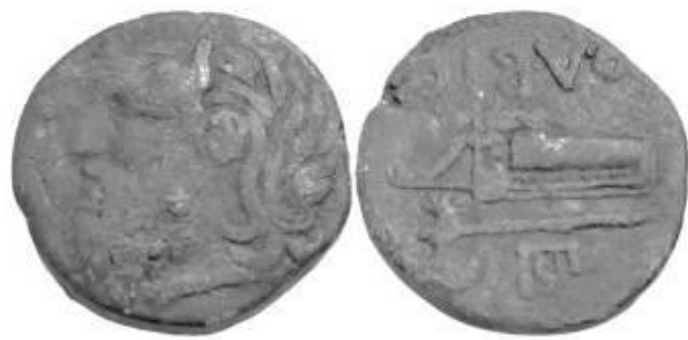

14

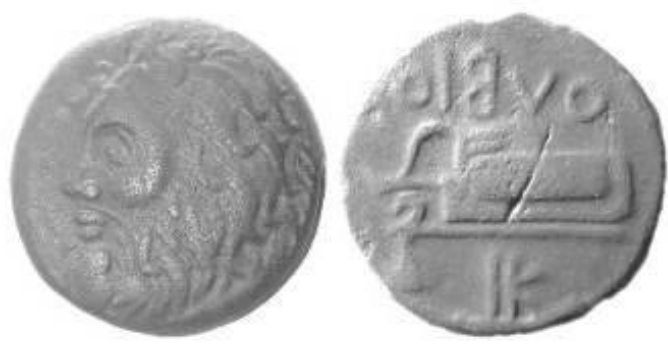

16

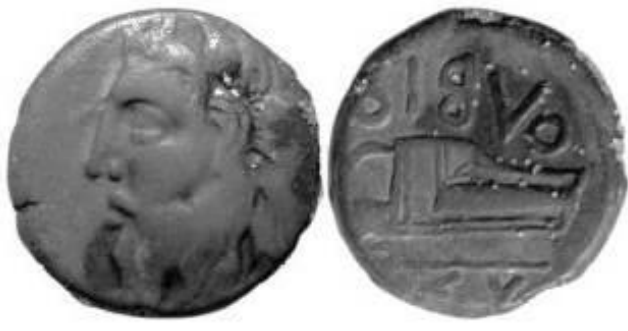

18

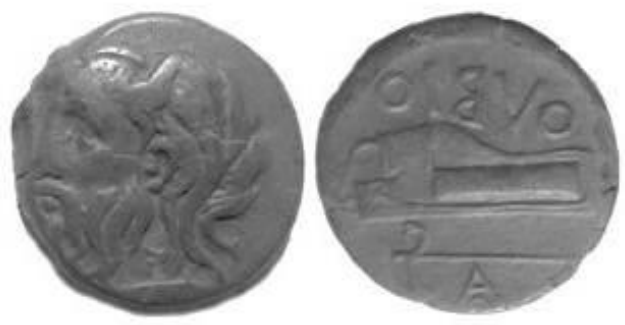

20

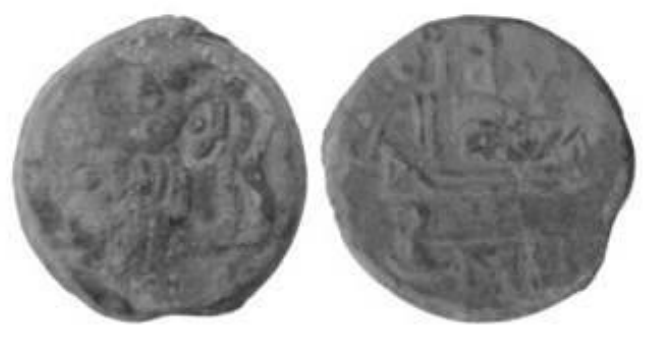

22

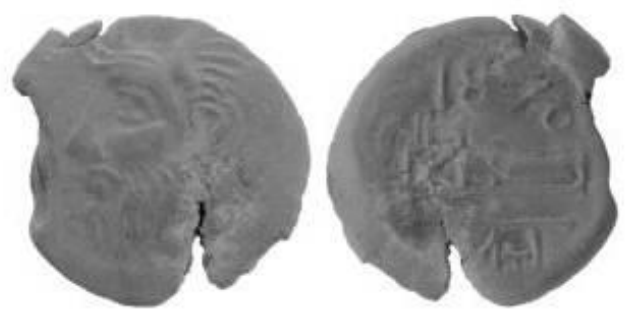

24
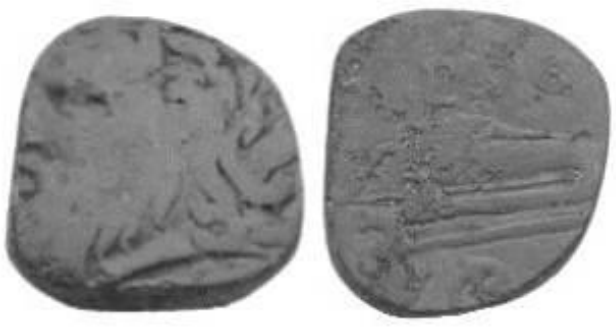

15
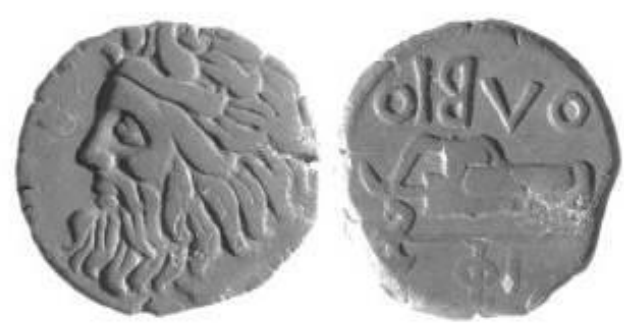

17

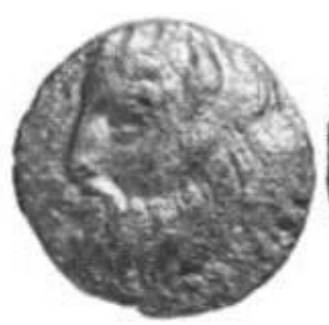

19

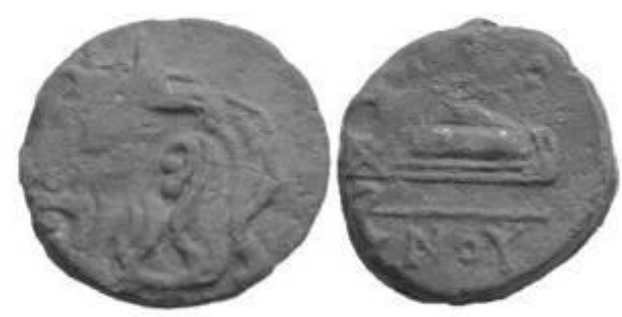

21

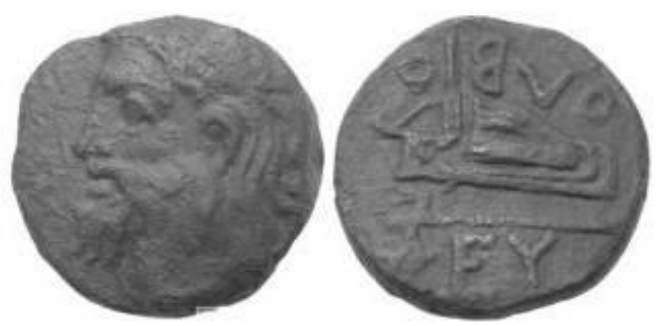

23

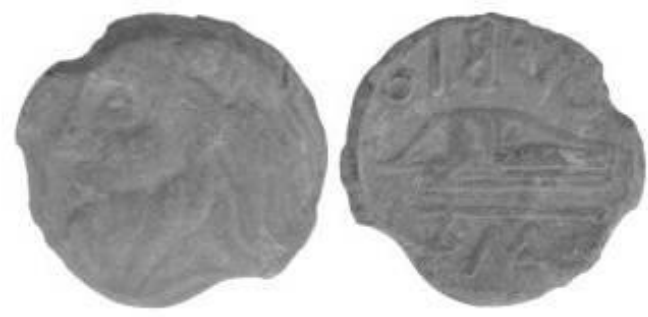

25 


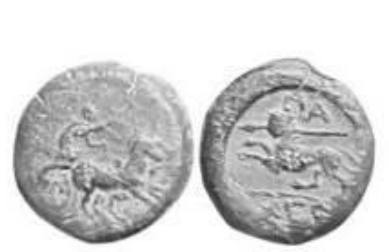

26

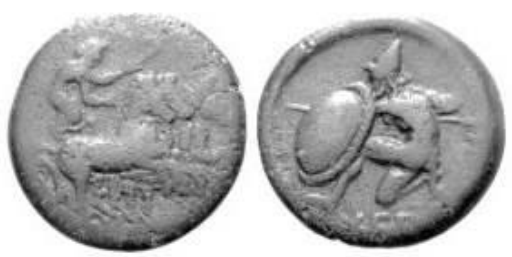

27

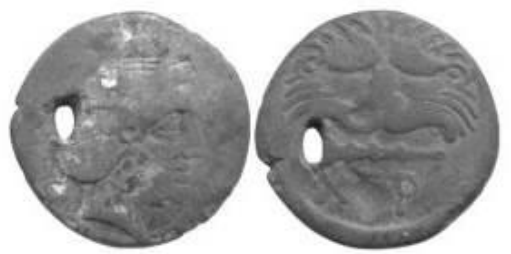

28

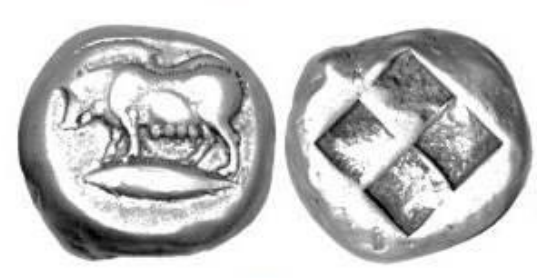

29

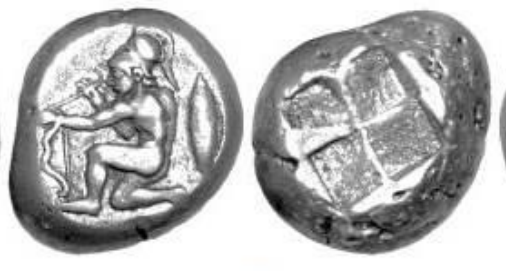

30

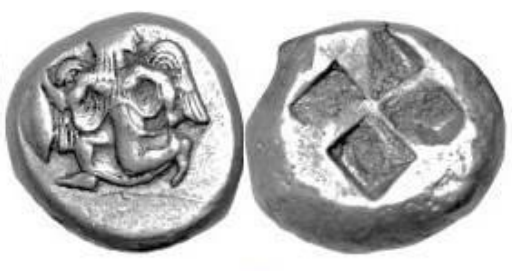

31

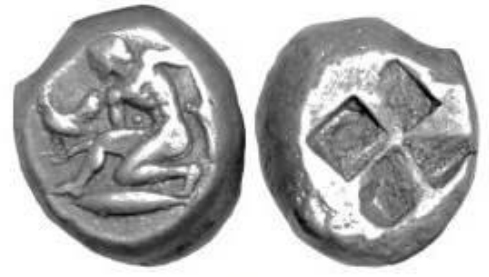

32

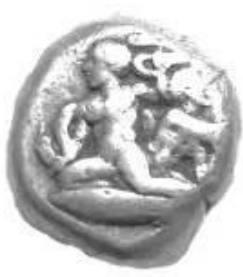

33

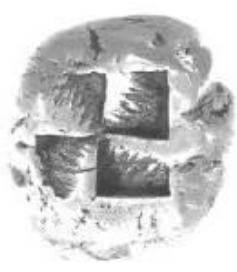

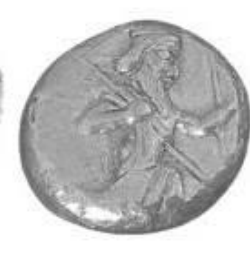

34

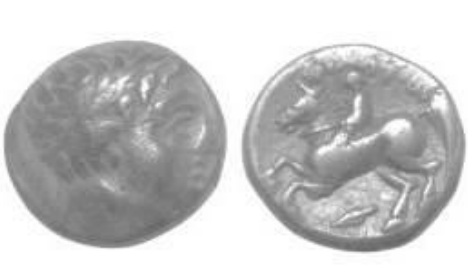

35
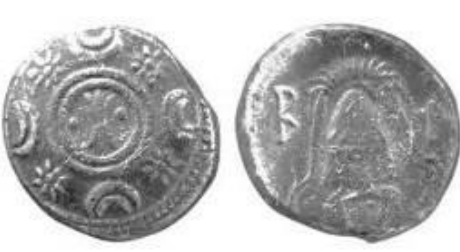

36

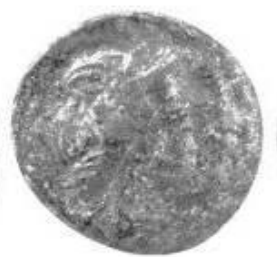

37

37
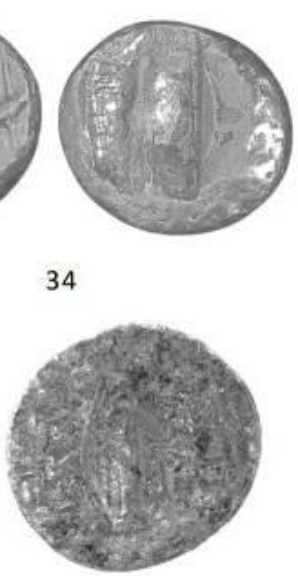
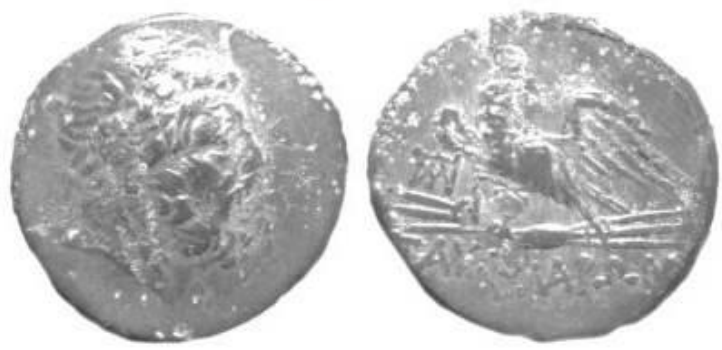

38

Рис.1

Монети VI-I ст. до н.е., знайдені в басейні р. Тясмин і на прилеглих територіях ${ }^{*}$

* Без масштабу 


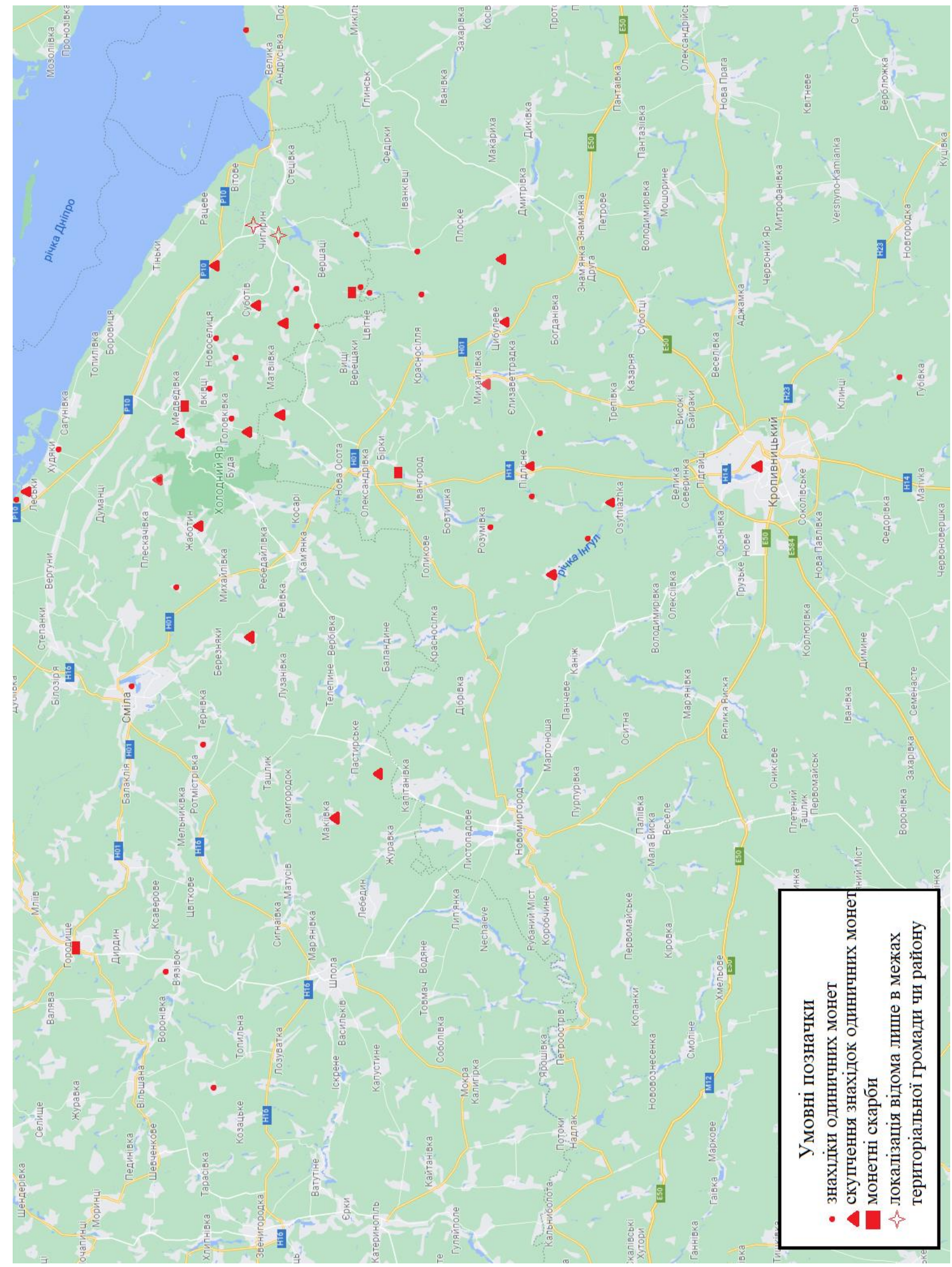

Рис. 2 Мапа знахідок

\section{References}

Anokhin, V. A. (2011). Antichnyye monety Severnogo Prichernomor'ya. [Antique coins of the Northern Black Sea coast]. Kyiv: Stilos. [in Russian]. 
Anokhin, V.O. (1971). Torhivlya ta hroshovyy obih. In Arkheolohiya Ukrayins'koyi RSR. (Vol. 2). [Archeology of the Ukrainian SSR]. Kyiv: Naukova dumka, [in Ukrainian].

Bessonova, S. S., Poltavets', V. I. (2015). Shlyakhy spoluchennya v baseyni Tyasmynu na pochatku doby zaliza. [Ways of communication in the Tasmina basin at the beginning of the Iron Age.]. Arkheolohiya i davnya istoriya Ukrayiny: Starozhytnosti rann'oho zaliznoho viku. 2/15, 21-37. [in Ukrainian].

Bokiy, N. M. (1967). Okhrannyye raboty v Kirovogradskoy oblasti. [Security work in the Kirovograd region.]. Arkheologicheskiye issledovaniya na Ukraine 1965 1966 gg. 1, 110-114. [in Russian].

Bokiy, N. M. (1977). Rozkopky kurhaniv u verkhiv"yakh baseynu Tyasmyna. [Excavation of mounds in the upper reaches of the Tyasmin Basin.]. Arkheolohiya. 22, 65-73. [in Ukrainian].

Braychevs'kyy, M. (1964). Numizmatyka $v$ temakh davn'oyi istoriyi skhidnoslov'yans'kykh plemen [Numismatics in the themes of ancient history of East Slavic tribes]. Istorychni dzherela ta yikh vykorystannyayu. (1), 141-166. [in Ukrainian].

Gavrilyuk, N.A. (2013). Ekonomika Stepnoy Skifii VI - III vv. do n. e. [Economy of Steppe Skythia in $\mathrm{VI}^{\text {th }}-$ III $^{\text {rd }}$ ]. Kiev [in Russian].

Grakov, B.N. (1971). Skify [Scythians]. Moscow: Izdatel'stvo MGU [in Russian].

Grierson, P. (1975). Numismatics. Oxford: University Press.

Herodot. 1993. Istoriyi $v$ dev'yaty knyhakh [Stories in nine books]. Kyiv: Naukova dumka [in Ukrainian].

Il'inskaya, V.A., Terenozhkin A.I. (1983). Skifiya VII-IV vv. do n.e. [Scythia VII IV centuries BC]. Kiev: Naukova Dumka. [in Russian].

Karyshkovskiy, P.O. (1988). Monety Ol'vii. Ocherk denezhnogo obrashcheniya Severo-Zapadnogo Prichernomor'ya v antichnuyu epokhu. [Coins of Olbia. An outline of the monetary circulation of the North-Western Black Sea region in ancient times]. Kyiv: Naukova dumka. [in Russian].

Kotlyar, M. F. (1971). Hroshovyy obih na terytoriyi Ukrayiny doby feodalizmu [Money circulation on the territory of Ukraine in the era of feudalism]. Kyiv: Naukova dumka. [in Ukrainian].

Kotsur, V. (2017). Istoriohrafiya ukrayins'koho skarboznavstva. [Historiography of the Ukrainian Treasurology.]. Ukrainskyi numizmatychnyi shchorichnyk The Ukrainian Numismatic Annual, 1, 15-32. [in Ukrainian].

Kryzhyts'kyy, S.D. (1998). Ol'viya u 331r. - seredyni I st. do n.e. In P.P. Tolochko (Ed.), Davnya istoriya Ukrayiny (Vol 2, pp. 315-329). [Ancient history of Ukraine]. Kyiv [in Ukrainian].

Lyashko, YU. (2017-a) Antychni monety z bereha richky Tyasmyn. [Antique coins from the bank of the river Tyasmin]. Abstracts of Papers: Arkheolohiya \& 
Fortyfikatsiya Ukrayiny VII Vseukrayins'ka naukovo-praktychna konferentsiya. (pp. 359-361). Kam"yanets'-Podil's'kyy. [in Ukrainian].

Lyashko, YU.YU. (2017-b). Nove velyke poselennya skifs'koho chasu v okolytsyakh Motronyns'koho horodyshcha [A new large settlement of Scythian times in the vicinity of Motroninsky settlement]. Arkheolohiya $i$ davnya istoriya Ukrayiny. 2, 299-302. [in Ukrainian].

Maksimov, Ye.V. (1982). Zarubinetskaya kul'tura na territorii USSR. [Zarubinets culture on the territory of the USSR.]. Kyiv: Naukova dumka. [in Russian].

Mielczarek, M. \& Orlyk, V. (2019). New find of Olbian coins. Tarashcha district, Kyiv region, Ukraine. Skhidnoievropeiskyi Istorychnyi Visnyk [East European Historical Bulletin], 13, 33-39.

Mielczarek, M. (1989). Ancient Greek coins found in Central, Eastern, and Northern Europe. Zakład Narodowy Imienia Ossolińskich.

Murzin, V.YU. (1998). Naselennya Skifiyi ta sumizhnykh oblastey. In P. P. Tolochko (Ed.), Davnya istoriya Ukrayiny (Vol 2, pp. 72-106). [Ancient history of Ukraine]. Kyiv [in Ukrainian].

Myzgin, K. V. (2015). Do pytannya krytyky numizmatychnykh dzherel (na prykladi vyvchennya znakhidok antychnykh monet na terytoriyi Skhidnoyevropeys'koho Barbarykumu). [On the question of criticism of numismatic sources (on the example of studying the findings of ancient coins in the Eastern European Barbaricum)]. Visnyk Kharkivs'koho natsional'noho universytetu imeni V.N. Karazina. Seriya: Istoriya. 2015. 1145, 50, 179-188. [in Ukrainian].

Nechytaylo, V.V. (2000). Katalog antichnykh monet Ol'vii (VI v. do n.e. - III v. n.e). [Catalog of antique coins of Olbia (VI century BC - III century AD)]. Kyiv: [In Russian].

Nikolaev, M.I. (2020). Khronolohiya ol'viys'kykh «borysfeniv». [The chronology of Olbian 'Borysthenes']. Ukrainskyi numizmatychnyi shchorichnyk - The Ukrainian Numismatic Annual, 4, 14-42. [in Ukrainian].

Nikolaev, N. I. (2014). Prosopografija Ol'vii Pontijskoj V v. do n. je. - I v. n. je. [Prosopography of Olbia Pontika V cent. B.C. - I cent. A. D.]. Kyiv: [In Russian].

Orlyk, O. P. (2014). Poselennya rann'oskifs'koho chasu v verkhiv yakh richok Inhulu, Inhul'tsya ta Tyasmyn. [Settlement of early Scythian times in the upper reaches of the rivers Ingul, Ingulets and Tyasmin]. Naukovi zapysky. Seriya: Istorychni nauky. (21), 174-181. [in Ukrainian].

Orlyk, V. \& Orlyk, S. (2019). Teoretyko-metodolohichni ta dzhereloznavchi problemy ekonomichnoyi istoriyi Ukrayiny. [Theoretical-methodological and sourcestudying problems of the Economic history of Ukraine]. Universum Historiae et Archeologiae. 2/2, 5-26. [in Ukrainian].

Orlyk, V. (2020-a). Znakhidky monet Pontiys'koyi derzhavy Mitridata Yevpatora na terytoriyi Dniprovs'koho Pravoberezhnoho Lisostepu. [Finds of Coins of 
Kingdom of Pontus of Mithridates Eupator on the Territory of the Right BankDnipro Forest-Steppe]. Ukrayins'kyy istorychnyy zhurnal - Ukrainian Historical Journal, 6, .93-103. [in Ukrainian].

Orlyk, V. (2020-b). Do pytannya isnuvannya hroshovoho obihu na terytoriyi Dniprovs'koho Pravoberezhnoho Lisostepu (V-I st. do n.e.). [On the question of the existence of money circulation on the territory of the Dnieper Right-Bank Forest-Steppe (V-I centuries BC)]. Abstracts of Papers: Istoriya, arkheolohiya, informatsiyna, bibliotechna ta arkhivna sprava: aktual'ni problemy nauky ta osvity. (pp. 9-13). Kropyvnyts'kyy. [in Ukrainian].

Orlyk, V. (2020-c). Znakhidky v baseyni $r$. Tyasmynu midnykh monet Ol'viyi z Demetroyu ta «istriys'kym» variantom mis'koyi emblemy. [The finds in the River basin of Tiasmyn copper coins of Olbia with the Demeter and «Istrian» variant of the city emblem]. Ukrainskyi numizmatychnyi shchorichnyk - The Ukrainian Numismatic Annual, 4, 5-13. [in Ukrainian].

Orlyk, V. (2021-a). Do pytannya isnuvannya hroshovoho obihu $v$ naselennya lisostepovoyi zony Pravoberezhnoyi Naddnipryanshchyny $v$ V-I st. do n.e. [On the question of the existence of money circulation in the population of the forest-steppe zone of the Right-Bank Dnieper region in the V-I centuries B.C.]. Abstracts of Papers: Problemy i perspektyvy numizmatyky Antychnoyi ta Ryms'koyi doby na terenakh Pivdenno-Skhidnoyi Yevropy, I Mizhnarodnyy fakhovyy seminar, prysvyachenyy pam"yati V. O. Anokhina, 26 veresnya 2019 roku. (pp. 9-11). Medzhybizh - Zhytomyr. [in Ukrainian].

Orlyk, V. (2021-b). Ridkisnyy stater Kyzikina chetvertoyi hrupy z Kirovohradshchyny. [Rare stator of Kizikin of the fourth group from Kirovograd region]. Abstracts of Papers: Aktual'ni problemy numizmatyky u systemi spetsial'nykh haluzey istorychnoyi nauky: tezy dopovidey VI-yi mizhnarodnoyi naukovoyi konferentsiyi, 17-18 veresnya 2020 r. (pp. 14-16). Pereyaslav - Kropyvnyts'kyy - Kyiv. [in Ukrainian].

Orlyk, V., \& Orlyk, S. (2020). The New Find of a Bronze Coin of Kerkinitis in the Middle Dnieper Ukraine (Horodysche District, Cherkasy Region, Ukraine). Danubius XXXVIII, Supliment. 9-23.

Orlyk, V., Kotsur, V., \& Tsyganenko, L. (2019). Klad ol'viyskikh monet «borisfenov», naydennyy $v$ Gorodishchenskom rayone Cherkasskoy oblasti vesnoy 2018 goda. [Hoard of Olbia coins «Borisfen», found in the Gorodishchensky district of the Cherkasy region in the spring of 2018]. Acta Archaeologica Lodziensia, 65, $37-$ 48. [in Russian]

Poltavets', V.I. (2016). Istoriya naselennya baseynu r. Tyasmyn v rann'omu zaliznomu vitsi (X - IV st. do n.e.). Pryrodno-hospodars'kyy aspekt. [History of the population of the Tyasmin river basin in the early Iron Age (X - IV centuries BC). Natural and economic aspect]. (Candidate's thesis). Kyiv. [in Ukrainian]. 
Sal'nykov, O.H. (1960). Antychni zoloti monety z kolektsiyi Odes'koho derzhavnoho arkheolohichnoho muzеyu. [Antique gold coins from the collection of the Odessa State Archaeological Museum]. Materyaly po arkheolohyy Severnoho Prychernomor'ya. 3, 243-249. [in Ukrainian].

Shestopal, A. V. (2007). Skarby Cherkashchyny. [Treasures Cherkasy region]. Cherkasy: Vyd. Androshchuk P.S. [in Ukrainian].

Shostopal, A.V. (2016). Nadkhodzhennya antychnykh monet na Serednye Podniprov'ya u skifs'kyy period. [Receipt of ancient coins in the Middle Dnieper in the Scythian period]. Abstracts of Papers: Chyhyrynshchyna: istoriya $i$ s'ohodennya. V naukovo-praktychna konferentsiya 12-13 lystopada 2015 r. (pp. 25-28). Cherkasy, [in Ukrainian].

Skoryy, S. \& Zimovets, R. (2014). K probleme tovarno-denezhnykh otnosheniy u naseleniya Vostochnoyevropeyskoy Lesostepi $v$ skifskuy epokhu. [On the problem of commodity-money relations among the population of the Eastern European Forest-Steppe in the Scythian era] Naukovi zapysky Kirovohrads'koho derzhavnoho pedahohichnoho universytetu imeni Volodymyra Vynnychenka. Seriya: Istorychni nauky, 21, 141-156 [in Russian].

Terenozhkin, A. I. (1952). Poseleniya i gorodishcha $v$ basseyne reki Tyasmina. [Settlements and settlements in the Tyasmina river basin]. Kratkiye soobshcheniya Instituta istorii material'noy kul'tury. XLIII, 80-98. [in Russian].

Turovskiy, Ye. YA. (2014). Monetnoye delo Khersonesa: mezhdu Mitridatom Yevpatorom i imperatorom Tiberiyem (63 g. do n. e. -37 g. n. e.). [Mint of Chersonesus: between Mithridates Eupator and Emperor Tiberius (63 BC - 37 AD)]. Stratum plus, 6, 307-314. [in Russian]. 